University of Nebraska - Lincoln

DigitalCommons@University of Nebraska - Lincoln

Stephen DiMagno Papers

Published Research - Department of Chemistry

$5-2011$

\title{
Unprecedented Directing Group Ability of Cyclophanes in Arene Fluorinations with Diaryliodonium Salts
}

Joseph W. Graskemper

University of Nebraska-Lincoln, jgraskemper@huskers.unl.edu

Bijia Wang

University of Nebraska - Lincoln

Linlin Qin

University of Nebraska - Lincoln

Kiel D. Neumann

University of Nebraska - Lincoln

Stephen G. DiMagno

University of Nebraska-Lincoln, sdimagno@uic.edu

Follow this and additional works at: https://digitalcommons.unl.edu/chemistrydimagno

Part of the Chemistry Commons

Graskemper, Joseph W.; Wang, Bijia; Qin, Linlin; Neumann, Kiel D.; and DiMagno, Stephen G., "Unprecedented Directing Group Ability of Cyclophanes in Arene Fluorinations with Diaryliodonium Salts" (2011). Stephen DiMagno Papers. 2.

https://digitalcommons.unl.edu/chemistrydimagno/2

This Article is brought to you for free and open access by the Published Research - Department of Chemistry at DigitalCommons@University of Nebraska - Lincoln. It has been accepted for inclusion in Stephen DiMagno Papers by an authorized administrator of DigitalCommons@University of Nebraska - Lincoln. 


\title{
Unprecedented Directing Group Ability of Cyclophanes in Arene Fluorinations with Diaryliodonium Salts
}

\author{
Joseph W. Graskemper, Bijia Wang, Linlin Qin, Kiel D. Neumann, and Stephen G. DiMagno \\ Department of Chemistry and Nebraska Center for Materials and Nanoscience, \\ University of Nebraska-Lincoln, Lincoln, Nebraska 68588-0304, USA \\ Corresponding author - S. G. DiMagno, sdimagno1@unl.edu
}

\section{Abstract}

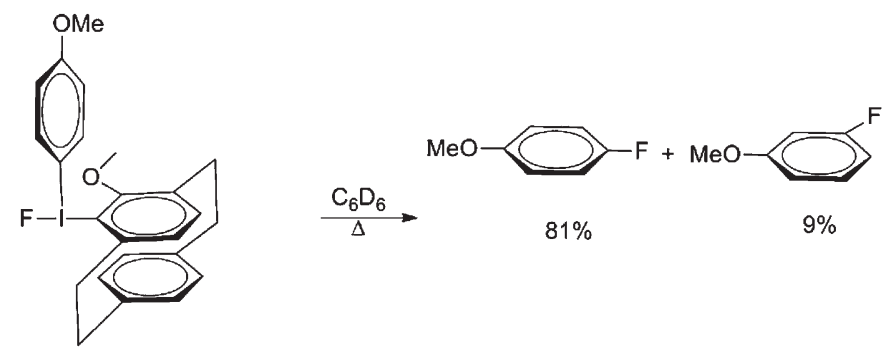

For the first time it is shown that exceptionally electron-rich arene rings can be fluorinated exclusively during the reductive elimination reactions of diaryliodonium fluorides. The 5-methoxy[2.2]paracyclophan-4-yl directing group simultaneously reduces unproductive aryne chemistry and eliminates ligand exchange reactions by a combination of steric and electronic effects. Use of the cyclophane directing group permits an unprecedented degree of control in fluorination reactions of diaryliodonium salts.

Rapid late-stage introduction of fluorine into biologically active compounds is essential for the synthesis of ${ }^{18} \mathrm{~F}$ labeled radiotracers for positron emission tomography. ${ }^{1-3}$ Although significant advances in electrophilic radiofluorination have been made recently, ${ }^{4}$ nucleophilic, fluoridebased approaches to radiotracers are preferred in imaging applications where radiochemical purity is essential. ${ }^{5}$ For aromatic compounds bearing electron-withdrawing groups, nucleophilic aromatic substitution $\left(S_{N} A r\right)$ of halide, nitro, or trimethylamine leaving groups by fluoride is a highly efficient process. ${ }^{6-10}$ However, functionalization of electron-rich arenes with fluoride requires mediation by transition metal ${ }^{11}$ or hypervalent main group atoms.

The reductive elimination of aryl fluorides from diaryliodonium salts was pioneered by Pike for arene radiofluorination. ${ }^{12-14}$ Aided by our access to anhydrous fluoride reagents, ${ }^{15}$ we were able to demonstrate that removal of inorganic salts from the reaction medium and the use of relatively nonpolar solvents dramatically increase the yields of fluorinated arenes from diaryliodonium fluorides. ${ }^{16}$ Here we address some of the remaining roadblocks to efficient fluorination using I(III) compounds.
1. Positron Emission Tomography: Basic Sciences; Bailey, D. L., Townsend, D. W., Falk, P. E., Maisey, M. N., Eds.; Springer: London, 2005.

2. Welch, M. J.; Redvanly, C. S. Handbook of Radiopharmaceuticals - Radiochemistry and Applications; Wiley: Chichester, 2003.

3. Fluorine in Pharmaceutical and Medicinal Chemistry: From Biophysical Aspects to Clinical Applications; Gouverneur, V., Mueller, K., Eds.; World Scientific: 2011.

4. Teare, H.; Robins, E. E.; Kirjavainen, A.; Forsback, S.; Sandford, G.; Solin, O.; Luthra, S. K.; Gouverneur, V. Angew. Chem., Int. Ed. 2010, 49, 6821

5. Cai, L.; Lu, S.; Pike, V. W. Eur. J. Org. Chem. 2008, 2853

6. Sun, H.; DiMagno, S. G. Angew. Chem., Int. Ed. 2006, 45, 2720

7. Sun, H.; DiMagno, S. G. J. Fluorine Chem. 2007, 128, 806
8. Adams, D. J.; Clark, J. H. Chem. Soc. Rev. 1999, 28, 225

9. Boechat, N.; Clark, J. H. J. Chem. Soc., Chem. Commun. 1993, 921

10. Maggini, M.; Passudetti, M.; Gonzales-Trueba, G.; Prato, M.; Quintily, U.; Scorrano, G. J. Org. Chem. 1991, 56, 6406

11. Watson, D. A.; Su, M.; Teverovskiy, G.; Zhang, Y.; Garcia-Fortanet, J.; Kinzel, T.; Buchwald, S. L. Science 2009, 325, 1661

12. Pike, V. W.; Aigbirhio, F. I. J. Chem. Soc., Chem. Commun. 1995, 2215

13. Shah, A.; Pike, V. W.; Widdowson, D. A. J. Chem. Soc., Perkin Trans. 1 1997, 2463

14. Shah, A.; Pike, V. W.; Widdowson, D. A. J. Chem. Soc., Perkin Trans. 1 1998, 2043

15. Sun, H.; DiMagno, S. G. J. Am. Chem. Soc. 2005, 127, 2050

16. Wang, B.; Qin, L.; Neumann, K. D.; Uppaluri, S.; Cerny, R. L.; DiMagno, S. G. Org. Lett. 2010, 12, 3352 

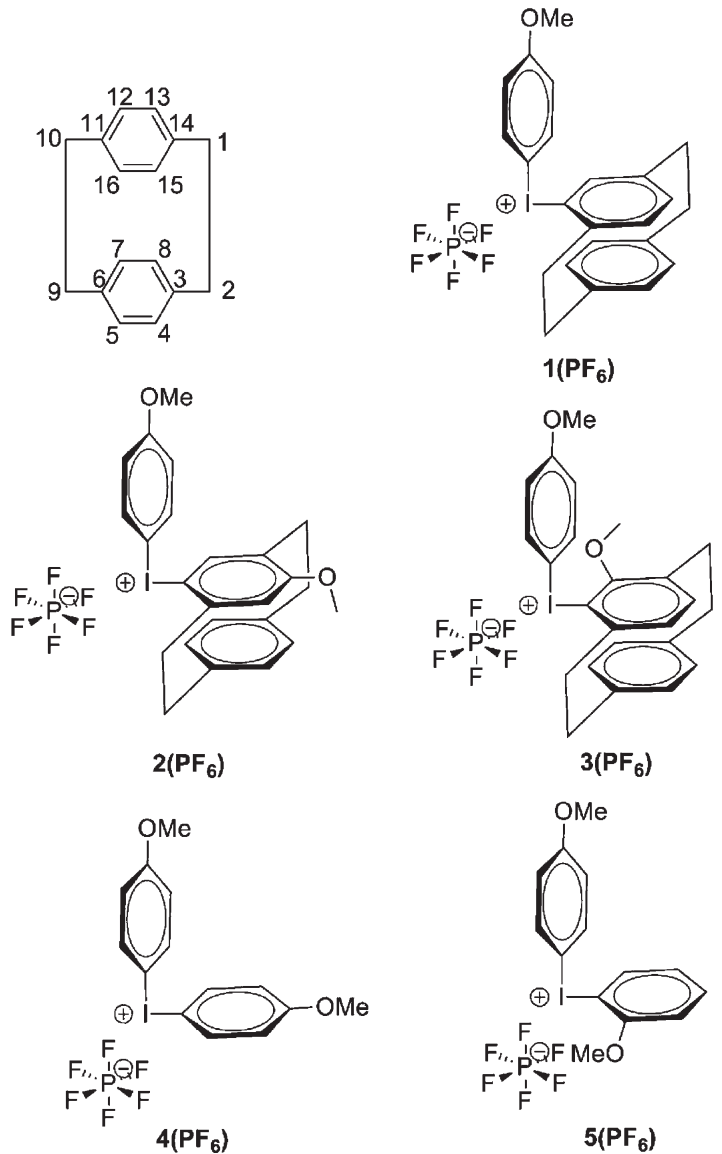

Figure 1. Numbering of the [2.2]paracyclophane ring system and the structures of the diaryliodonium hexafluorophosphate salts discussed in this work.

The reductive elimination regiochemistry of diaryliodonium fluorides is generally controlled by electronic substituent effects; the most electron-poor ring is fluorinated selectively, and the electron-rich aryl iodide is eliminated. However, the extent to which electronic control can be utilized is limited, since highly electron-rich rings promote nonproductive decomposition reactions of diaryliodonium salts, presumably by inner-sphere redox processes. As an example, diaryliodonium salts featuring 4-(dialkylamino)phenyl groups have not been isolated, despite attempts to do so. ${ }^{17}$ A second consideration is the surprisingly labile nature of aryl rings on I(III) fluorides; we demonstrated recently that rapid aryl group exchange among diaryliodonium fluorides occurs at room temperature in acetonitrile. ${ }^{18}$ Here we show that appropriately substituted cyclophane ligands on iodine solve simultaneously the ligand exchange and regiospecificity problems by means of the same stereoelectronic effect.

17. Beringer, F. M.; Chang, L. L. J. Org. Chem. 1972, 37, 1516

18. Wang, B.; Cerny, R. L.; Uppaluri, S.; Kempinger, J. J.; DiMagno, S. G. J. Fluorine Chem. 2010, 131, 1113

19. Wang, B.; Graskemper, J. W.; Qin, L.; DiMagno, S. G. Angew. Chem., Int. Ed. 2010, 49, 4079

20. Bordwell, F. G. Acc. Chem. Res. 1988, 21, 456

21. Christe, K. O.; Wilson, W. W.; Wilson, R. D.; Bau, R.; Feng, J. A. J. Am. Chem. Soc. 1990, 112, 7619
Paracyclophane substituents have been shown to be superior directing groups for reductive elimination reactions of diaryliodonium salts; ${ }^{19}$ regiospecificity is obtained even when electron-rich aryl rings, such as 4-methoxyphenyl, are functionalized. Significant out of plane steric bulk provided by the "capping" aryl ring results in a highly congested, strongly destabilized (by $>4 \mathrm{kcal} / \mathrm{mol}$ ) transition state for cyclophane functionalization. A rise in the free energy of activation for cyclophane functionalization steers the nucleophile toward the second aryl substituent. Regiospecific arene functionalization was demonstrated with the weakly basic azide, acetate, phenoxide, thiocyanate, and thiophenoxide nucleophiles. However, regiocontrol was lost when the more strongly basic trifluoroethoxide nucleophile was used; this basic group appeared to promote a mode of decomposition that involved formation of aryne intermediates. ${ }^{19}$ The similar basicities of fluoride and trifluoroethoxide in polar aprotic solvents $\left(\mathrm{CF}_{3} \mathrm{CH}_{2} \mathrm{OH}, \mathrm{pK}\right.$ a $=$ 23.5; $\mathrm{HF}, \mathrm{pK} K_{\mathrm{a}}=15$ in DMSO ${ }^{20}$ implied that aryne chemistry could also be a significant side reaction in cyclophane directed fluorinations of diaryliodonium salts.

(4-Methoxyphenyl)([2.2]paracyclophan-4-yl)iodonium hexafluorophosphate $\mathbf{1}\left(\mathbf{P F}_{6}\right)$ and (4-methoxyphenyl) ((7-methoxy[2.2]paracyclophan-4-yl)iodonium hexafluorophosphate $\mathbf{2}\left(\mathbf{P F}_{6}\right)$ (Figure 1) were prepared as described previously ${ }^{19}$ and converted to the fluoride salts by ion exchange with anhydrous tetramethylammonium fluoride ${ }^{21}$ (TMAF) in acetonitrile. The residual $\mathrm{TMAPF}_{6}$ was removed by evaporation of the solvent, suspension of the remaining solid in benzene, and passage of this solution through a $0.2 \mu \mathrm{m}$ PTFE filter. NMR $\left({ }^{1} \mathrm{H}\right.$ and $\left.{ }^{19} \mathrm{~F}\right)$ and ES-MS spectra of 1(F) and 2(F) were consistent with a single species in solution, indicating that fluoride-promoted aryl group exchange in diaryliodonium fluorides is suppressed by the cyclophane substituent. Thermal decomposition reactions of $\mathbf{1}(\mathbf{F})$ and $2(\mathbf{F})\left(140{ }^{\circ} \mathrm{C}, d_{6}\right.$-benzene, $\left.15 \mathrm{~min}\right)$ gave a mixture of fluorinated products (Figure 2). The relatively poor selectivity observed for arene fluorination contrasts strongly with the excellent selectivity observed previously for weakly basic nucleophiles (Table 1). Tellingly, roughly equal amounts of 4-fluoro-7-methoxy[2.2]paracyclophane and 4-fluoro-8-methoxy[2.2]paracyclophane were formed during the thermal decomposition reaction of $\mathbf{2}(\mathbf{F})$, implicating arynes as likely reactive intermediates. Although the greater susceptibility of the relatively electron-rich cyclophane ligand to deprotonation is not well understood currently, we pursued a simple blocking strategy to suppress aryne formation and to restore regiocontrol.

(4-Methoxyphenyl)(5-methoxy[2.2]paracyclophan-4-yl) iodonium hexafluorophosphate, $\mathbf{3}\left(\mathbf{P F}_{6}\right)$, in which both sites ortho to the I(III) center are substituted, was synthesized from 4-bromo[2.2]paracyclophane, ${ }^{22}$ as is shown in Figure 3. Metal-halogen exchange yielded the organolithium reagent, which was quenched with trimethylborate and oxidized with hydrogen peroxide. ${ }^{23}$ To introduce a halogen

22. Cram, D. J.; Day, A. C. J. Org. Chem. 1966, 31, 1227

23. Krohn, K.; Rieger, H.; Hopf, H.; Barrett, D.; Jones, P. G.; Doering, D. Chem. Ber. 1990, 123, 1729 


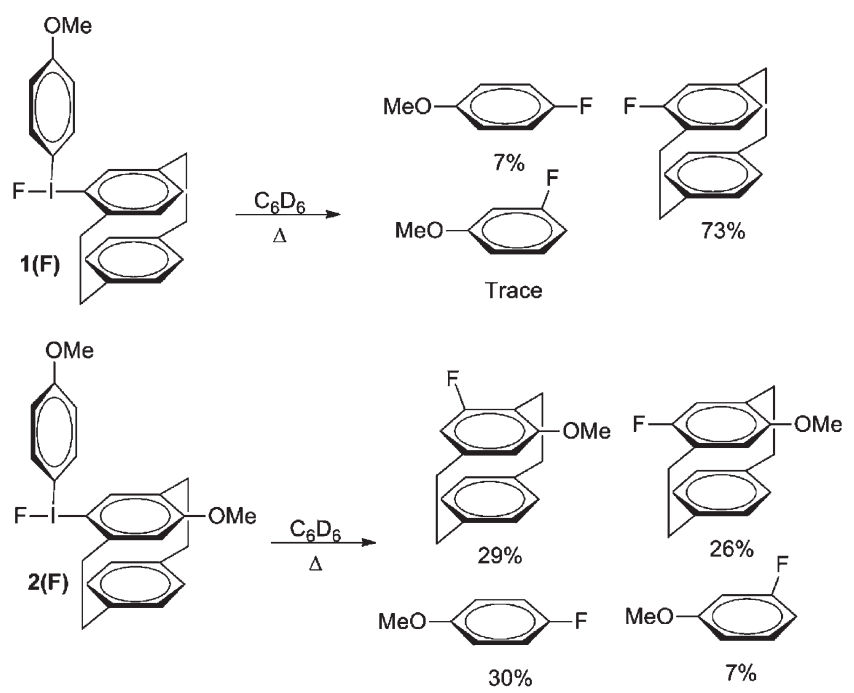

Figure 2. Thermal decomposition of [2.2]paracyclophane-substituted diaryliodonium fluorides $\mathbf{1}(\mathrm{F})$ and $\mathbf{2}(\mathrm{F})$.

Table 1. Yields ${ }^{a}$ of Reductive Elimination Products from $\mathbf{1}(\mathbf{X})$ and $\mathbf{2}(\mathbf{X})$ with Various Nucleophiles

\begin{tabular}{|c|c|c|c|c|}
\hline \multirow[b]{2}{*}{ X } & \multicolumn{2}{|c|}{$1(X)$} & \multicolumn{2}{|l|}{$2(X)$} \\
\hline & MeOPh-Xa & Сус- $X^{a}$ & MeOPh-X & Сус-X \\
\hline $\mathrm{N}_{3}$ & 86 & 14 & 96 & 0 \\
\hline SCNN & 81 & 18 & 92 & 0 \\
\hline OPh & 51 & 40 & 84 & 0 \\
\hline SPh & 43 & 52 & 82 & 0 \\
\hline OAC & 68 & 31 & 51 & 0 \\
\hline $\mathrm{OCH}_{2} \mathrm{CF}_{3}$ & 19 & 39 & $42^{b}(22+20)$ & $37^{b}(18+19)$ \\
\hline $\mathrm{F}$ & 7 & 73 & $37^{b}(30+7)$ & $55^{b}(29+26)$ \\
\hline
\end{tabular}

a. All yields were determined by ${ }^{1} \mathrm{H}$ NMR spectroscopy and confirmed by GC-MS. The products are functionalized anisoles (MeOPh-X) and functionalized paracyclophanes (Сус-X).

b. Total amount of two different regioisomers. Numbers in parentheses refer to the total amount of expected and rearranged functionalized product, respectively.

atom at the 5-position, ortho-lithiation required installation of the diethylcarbamoyl directing group, as was reported previously. ${ }^{24,} 25$ (Direct lithiation of 4-methoxy-[2.2]paracyclophane was not successful in our hands; modeling indicated that steric congestion forces the methyl group above the cyclophane ring, thereby aligning the oxygen lone pairs in an inappropriate geometry to coordinate an incoming organolithium reagent.) Transmetalation with zinc chloride was essential for successful introduction of the 4-methoxyphenyliodonium diacetate moiety; the corresponding cyclophanyltributylstannane could not be coaxed to "transmetalate" with 4-methoxyphenyliodonium diacetate under any standard conditions. ${ }^{26}$

$\mathbf{3}\left(\mathbf{P F}_{6}\right)$ was converted to $\mathbf{3}(\mathrm{F})$ by ion exchange with anhydrous TMAF in acetonitrile and desalted according to the procedure described previously for 2 (F). ${ }^{1} \mathrm{H}$ NMR spec-

24. Hopf, H.; Barrett, D. G. Liebigs Ann. 1995, 449

25. Wack, H.; France, S.; Hafez, A. M.; Drury, W. J., III; Weatherwax, A.; Lectka, T. J. Org. Chem. 2004, 69, 4531

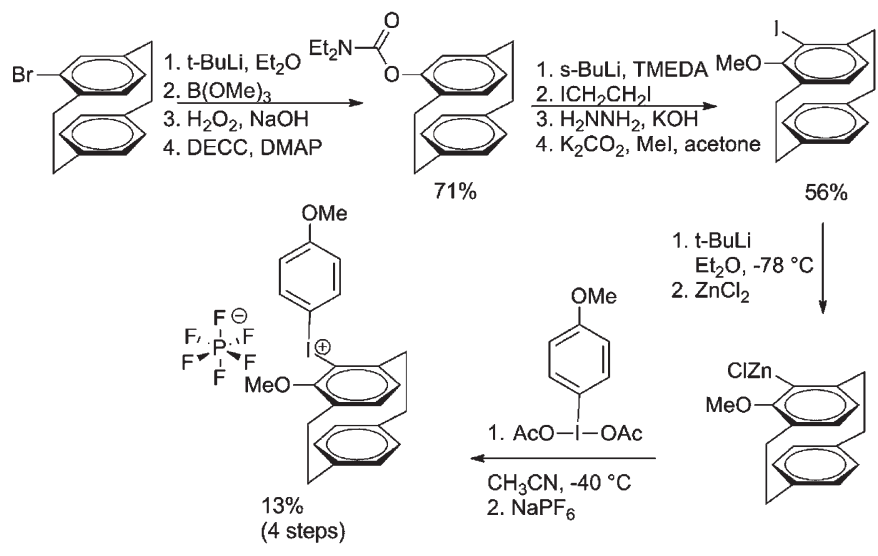

Figure 3. Synthesis of $\mathbf{3}\left(\mathrm{PF}_{6}\right)$.

tra of 3(F) in both acetonitrile and benzene showed no evidence of aryl group exchange.

Thermal decomposition of $3(\mathbf{F})$ at $140{ }^{\circ} \mathrm{C}(15 \mathrm{~min})$ gave a mixture of 4-fluoro- (72\%) and 3-fluoroanisole (15\%). Small amounts of inorganic silicon fluorides were also formed, presumably from the reaction of free fluoride or bifluoride with the borosilicate glass NMR tube. No fluorinated cyclophane was detected in the reaction mixture, supporting the hypothesis that aryne formation was largely responsible for the fluorocyclophanes observed during the thermal decomposition of 2(F), and confirming Chun and co-workers' observations that the methoxy group is not an effective ortho-director. ${ }^{27}$

In an attempt to gauge the temperature-dependence of the fluorination selectivity, thermolysis reactions of $3(\mathrm{~F})$ were also conducted at $80^{\circ} \mathrm{C}$ in benzene $(6 \mathrm{~h})$. Reactions run at this temperature were a bit more selective, but production of 3-fluoroanisole could not be suppressed completely (Figure 4).

The generation of significant amounts of 3-fluoroanisole from the decomposition of $\mathbf{3}(\mathbf{F})$ contrasts with the trace amounts formed under identical conditions from the symmetrical compound bis(4-methoxyphenyl)iodonium fluoride, 4(F). However, the more closely related, unsymmetrically substituted iodonium salt, (2-methoxyphenyl)(4-methoxyphenyl)iodonium fluoride, $5(\mathrm{~F})$, provides 2-fluoroanisole (59\%), 3-fluoroanisole (15\%), and 4-fluoroanisole $(25 \%)$ at high temperature (benzene, $140{ }^{\circ} \mathrm{C}$, $15 \mathrm{~min}$ ), and 2-fluoroanisole (65\%), 3-fluoroanisole (9\%), and 4 -fluoroanisole $(23 \%)$ at $80{ }^{\circ} \mathrm{C}$. These results suggest that a methoxy group ortho to the I(III) center promotes aryne formation. Modeling (B3LYP/DGDZVP, ZPE, and thermal corrections) of the ground state structures of the $4(F)$ and 5(F) along with the structures of the corresponding diaryliodonium cations (Figure 5) indicates that an ortho methoxy substituent stabilizes an I(III) center to a greater extent than a para methoxy group and reduces the

26. Pike, V. W.; Butt, F.; Shah, A.; Widdowson, D. A. J. Chem. Soc., Perkin Trans. 1 1999, 245

27. Chun, J.-H.; Lu, S.; Lee, Y.-S.; Pike, V. W. J. Org. Chem. 2010, 75, 3332 


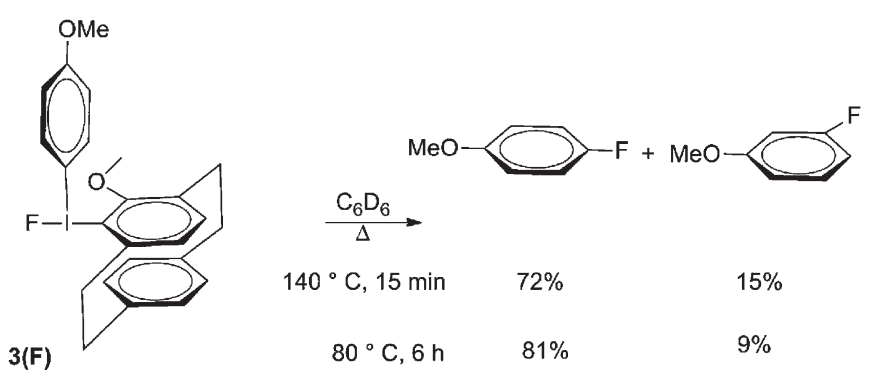

Figure 4. Thermal decomposition of 3(F).

gas phase fluoride ion affinity of the I(III) by $1.52 \mathrm{kcal} /$ mol. Weaker I-F interactions should lead to an increase in fluoride ion basicity, leading, in turn, to a more accessible aryne pathway.

In summary, here we have demonstrated that cyclophane-derived diaryliodonium salts bearing the electronrich 4-methoxyphenyl substituent can yield fluorinated anisoles exclusively. Previously, the 4-methoxyphenyl group was considered to be the "gold-standard" directing group for radiochemical fluorinations of diaryliodonium salts, and 4-fluoroanisole could not be obtained except in low yield from the symmetrical iodonium salt. ${ }^{12}$ The cyclophane ligand in 2(F) was shown to be resistant to fluorination through a reductive elimination pathway, but the combination of cyclophane steric demand and electron donation of the $p$-methoxy substituent enables easy access to a competing aryne fluorination pathway. Blocking of the position ortho to the I(III) center in $3(\mathrm{~F})$ precludes cyclophane aryne formation and results in exclusive fluorination of the anisole ring. The use of cyclophane as a directing group for I(III)-mediated fluorinations is a promising approach, particularly if highly electron-rich fluorinated aromatic compounds are the targets. Efforts are underway to streamline the synthesis of cyclophane-substituted diaryliodonium salts to make these compounds more accessible.
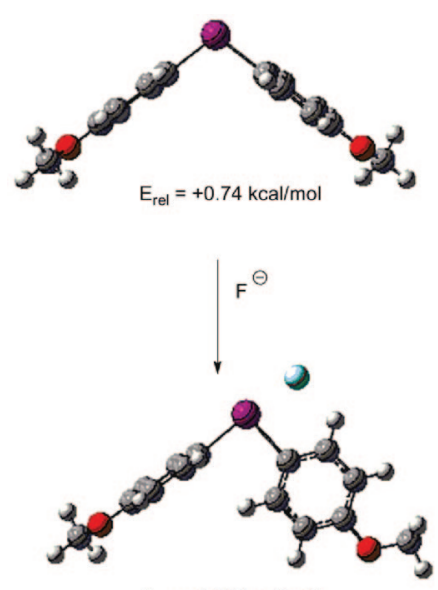

$E_{\text {rel }}=-0.78 \mathrm{kcal} / \mathrm{mol}$

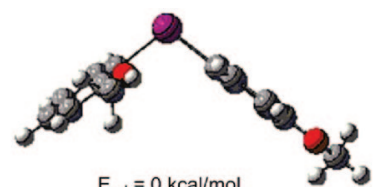

$\mathrm{E}_{\mathrm{rel}}=0 \mathrm{kcal} / \mathrm{mol}$

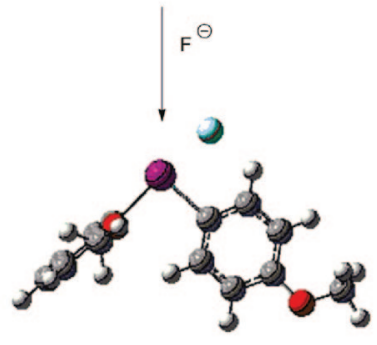

$\mathrm{E}_{\mathrm{rel}}=0 \mathrm{kcal} / \mathrm{mol}$

Figure 5. Calculated (B3LYP/DGDZVP) optimized structures and relative energies of the (2-methoxyphenyl)4-methoxyphenyliodonium cation (top right), the bis(4-methoxyphenyl)iodonium cation (top left), 4(F) (bottom left), and 5(F), bottom right.

Acknowledgments - We thank the National Science Foundation (CHE 0717562) for support and the National Institutes of Health (RR016544-01) for infrastructure to conduct this research.

Supporting Information - Experimental procedures and analytical data for all new compounds and synthetic intermediates are presented in the following pages. 


\section{Supporting Information for}

\section{Unprecedented Directing Group Ability of Cyclophanes in Arene Fluorinations with Diaryliodonium Salts}

Joseph W. Graskemper, Bijia Wang, Linlin Qin, Kiel D. Neumann, and Stephen G. DiMagno*

Department of Chemistry and Nebraska Center for Materials and Nanoscience, University of Nebraska, Lincoln, NE 68588-0304, USA. Fax: 402472 9402; Tel: 402472 9895; E-mail: sdimagno1@unl.edu

Table of Contents

Experimental procedures and data .

S2-S1 1

NMR spectra

S12-S49

References Cited 
Materials: All materials were obtained from commercial sources and used as received unless otherwise noted. Zinc chloride was dried in vacuo before use. Tetramethylammonium fluoride (TMAF) was dried at $60-80{ }^{\circ} \mathrm{C}$ in a drying pistol (charged with $\mathrm{P}_{2} \mathrm{O}_{5}$ ) under dynamic vacuum for one week. Acetonitrile and acetonitrile- $\mathrm{d}_{3}$ were heated at reflux over $\mathrm{P}_{2} \mathrm{O}_{5}$, distilled into flamedried storage tubes and stored under dry nitrogen. Benzene and benzene- $\mathrm{d}_{6}$ were heated at reflux over $\mathrm{CaH}_{2}$ overnight and distilled directly into flame-dried storage tubes under dry nitrogen. Tetrahydrofuran (THF) was dried over $\mathrm{Na}$ /benzophenone and distilled into a flame dried storage flask under dry nitrogen. All glassware, syringes, and NMR tubes were oven dried $\left(140{ }^{\circ} \mathrm{C}\right)$ for more than $24 \mathrm{~h}$ before they were transferred into the glove box for use. 1-(Diacetoxyiodo)-4methoxybenzene was synthesized according to our previously reported method. ${ }^{1}$ All NMR experiments reported here were performed using a Bruker Avance 400, 500, and $600 \mathrm{MHz} \mathrm{NMR}$ spectrometers in the NMR laboratory at the University of Nebraska-Lincoln. Yields from NMR scale reactions were determined by using the residual solvent peak as an internal standard. Reactions involving quantitative integration of fluorine NMR spectra were referenced to an add fluorotoluene standard. Additional product analyses were performed by GC-MS.

Calculations: All calculations were performed using the Gaussian ${ }^{2}$ suite of programs and visualization was performed with GaussView. Ground state geometries were identified after driving the C-C-I-H dihedral angle through a full range of motion. Structures were optimized and their energies calculated using DFT B3LYP/6-31G/DGDZVP methods. Frequency calculations on minimized structures were performed to make the zero point energy and thermal corrections. Transition states were optimized at the same computational level.

\section{Synthesis of cyclophanyliodonium salts:}

\section{([2.2]Paracyclophan-4-yl)(4'-methoxyphenyl)iodonium hexafluorophosphate, $1\left(\mathrm{PF}_{6}\right)$}

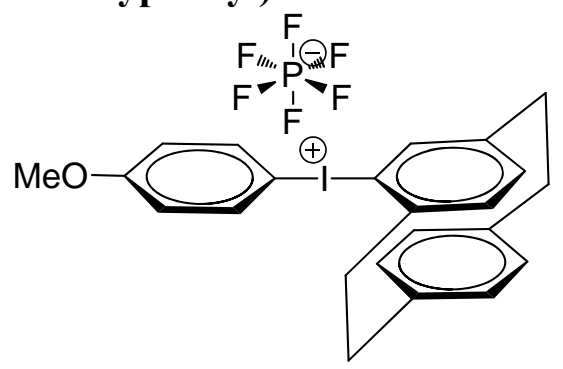

In a $50 \mathrm{~mL}$ Schlenk tube under nitrogen, a stirred solution of bromocyclophane (1 mmol, 282 $\mathrm{mg})$ in $10 \mathrm{~mL}$ of anhydrous diethyl ether was cooled to $-78^{\circ} \mathrm{C}$. A solution of $\mathrm{t}-\mathrm{BuLi}(1.7 \mathrm{M}$ in pentane, 2.3 equiv.) was added dropwise and the resulting mixture was stirred at $-78{ }^{\circ} \mathrm{C}$ for 20 minutes and then warmed to $0{ }^{\circ} \mathrm{C}$ and allowed to stir for an additional $20 \mathrm{~min}$. The reaction mixture was cooled again to $-78^{\circ} \mathrm{C}$ before a solution of zinc chloride $(200 \mathrm{mg}, 1.5 \mathrm{mmol})$ in ether $(10 \mathrm{~mL})$ was added dropwise by cannula. After the addition, the reaction mixture was allowed to warm to room temperature over the course of one hour before the solvents were removed in vacuo. The remaining solid was dissolved in anhydrous $\mathrm{CH}_{3} \mathrm{CN}$ and the solution was cooled to $-40{ }^{\circ} \mathrm{C}$ and added dropwise to precooled $\left(-40{ }^{\circ} \mathrm{C}\right)$ suspension of bis(acetyloxy)-(4methoxyphenyl)- $\lambda_{3}$-iodane $(352 \mathrm{mg}, 1 \mathrm{mmol})$ in $10 \mathrm{~mL}$ of acetonitrile. The mixture was allowed to warm to room temperature over 30 minutes before the solvent was removed in vacuo. The resulting solid was washed with hexanes and then dissolved in aqueous acetonitrile. Addition of an aqueous $\mathrm{NaPF}_{6}$ solution precipitated the product, which was extracted from the aqueous mixture with $\mathrm{CH}_{2} \mathrm{Cl}_{2}$. The organic layer was evaporated, dissolved in a minimal amount of 
$\mathrm{CH}_{2} \mathrm{Cl}_{2}$, precipitated with hexanes, filtered and dried in vacuo to yield 3 (225 $\mathrm{mg}, 38.4 \%$ yield). ${ }^{1} \mathrm{H}$ NMR $\left(\mathrm{CD}_{3} \mathrm{CN}, 400 \mathrm{MHz}, 25{ }^{\circ} \mathrm{C}\right): \delta 8.00(\mathrm{~d}, \mathrm{~J}=9.1 \mathrm{~Hz}, 2 \mathrm{H}), 7.27(\mathrm{~s}, 1 \mathrm{H}), 7.08(\mathrm{~d}, \mathrm{~J}=9.1$ $\mathrm{Hz}, 2 \mathrm{H}), 6.83(\mathrm{~d}, \mathrm{~J}=7.7 \mathrm{~Hz}, 1 \mathrm{H}), 6.76(\mathrm{~d}, \mathrm{~J}=7.7 \mathrm{~Hz}, 1 \mathrm{H}), 6.65(\mathrm{~s}($ broad $), 2 \mathrm{H}), 6.38(\mathrm{~d}, \mathrm{~J}=$ $7.9 \mathrm{~Hz}, 1 \mathrm{H}), 6.31(\mathrm{~d}, \mathrm{~J}=7.9 \mathrm{~Hz}, 1 \mathrm{H}), 3.84(\mathrm{~s}, 3 \mathrm{H}), 3.04-3.35(\mathrm{~m}, 8 \mathrm{H}) ;{ }^{13} \mathrm{C} \mathrm{NMR}\left(\mathrm{CD}_{3} \mathrm{CN}, 100\right.$ $\left.\mathrm{MHz}, 25^{\circ} \mathrm{C}\right) \delta 164.1,143.2,140.9,139.8,139.4,139.2,138.8,137.6,134.3,134.2,133.7,132.4$, 120.9, 119.4, 100.8, 56.7, 38.4, 35.6, 35.4, 35.3; HRMS: (HRFAB) calcd. for $\mathrm{C}_{23} \mathrm{H}_{22} \mathrm{OI}[\mathrm{M}]^{+}$ 441.07098, found 441.0712.

Fluorination 1(PF $)$ : In a $\mathrm{N}_{2}$ charged glove box, $11.7 \mathrm{mg} \mathrm{1( \mathbf {PF } _ { \mathbf { 6 } } )}(0.02 \mathrm{mmol})$ was dissolved in $0.3 \mathrm{~mL}$ of dry acetonitrile, to which a solution of $1 \mathrm{mg}$ anhydrous TMAF (1 equivalent ) in 0.3 $\mathrm{mL}$ of dry acetonitrile was added dropwise. The combined solution was transferred into a Schlenk flask, sealed and taken out of the glove box. Solvent was evaporated, and the remainder was taken back into the glove box and redissolved in $0.6 \mathrm{~mL}$ of $d_{6}$-benzene, passed through a 0.2 $\mu \mathrm{m}$ PTFE syringe filter, and transferred into a J-Young NMR tube. The tube was sealed, taken out of the box, and heated in a $140{ }^{\circ} \mathrm{C}$ oil bath for 15 minutes. Yields of fluorinated arenes were determined by ${ }^{1} \mathrm{H}$ and ${ }^{19} \mathrm{~F}$ NMR spectroscopy and confirmed by GC-MS. 4-Fluoro[2.2] paracyclophane was formed in 73\% yield, 4-fluoroanisole was formed in 7\% yield; 3fluoroanisole was detectable in GC-MS but barely shows up in ${ }^{19} \mathrm{~F}$ NMR spectrum, the remaining fluoride was incorporated in fluorosilicates and fluoroborates, presumably arising from the reaction of generated HF acting upon the borosilicate NMR tube.

(7-Methoxy[2.2]paracyclophan-4-yl)(4'-methoxyphenyl)iodonium hexafluorophosphate, 2(PF $)$

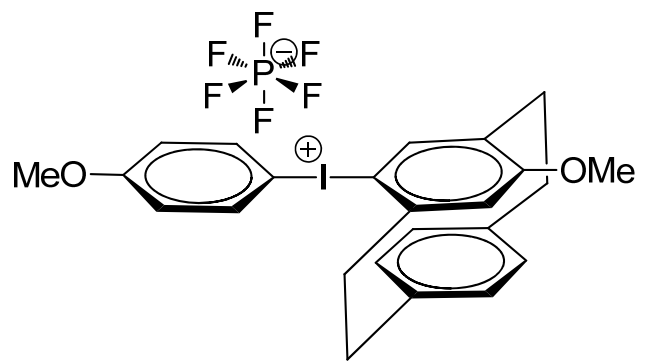

In a $100 \mathrm{~mL}$ Schlenk tube, 4-methoxy-7-bromo[2.2]paracyclophane (1.26 mmol, $400.6 \mathrm{mg})$ was dissolved in $25 \mathrm{~mL}$ of distilled ether and cooled to $-78^{\circ} \mathrm{C}$. To the cooled solution, 1.7M t-butyl lithium $\left(3.16 \mathrm{mmol}, 1.85 \mathrm{~mL}\right.$ ) was added dropwise and the stirred solution was held at $-78{ }^{\circ} \mathrm{C}$ for 1 hour. A solution of anhydrous zinc chloride $(1.51 \mathrm{mmol}, 206.1 \mathrm{mg})$ in $10 \mathrm{~mL}$ of diethyl ether was added dropwise to the cooled solution. The mixture was allowed to warm to room temperature, and the solvent was removed under reduced pressure. The residual solid (organozinc chloride reagent and lithium salts) was taken up in anhydrous acetonitrile and cooled to $-40{ }^{\circ} \mathrm{C}$ before a solution of 4-methoxy(diacetoxyiodo)benzene $(1.89 \mathrm{mmol}, 665.5 \mathrm{mg})$ in acetonitrile $(10 \mathrm{~mL})$ was added in a dropwise fashion. After 1 hour at $-40{ }^{\circ} \mathrm{C}$, the mixture was warmed to room temperature and the solvent was removed under reduced pressure. Deionized water and sodium hexafluorophosphate $(410 \mathrm{mg})$ were added, followed by $50 \mathrm{~mL}$ of dichloromethane. The mixture was transferred to a separatory funnel and the organic phase was separated. The solvent was removed by rotary evaporation and the remaining solid was dissolved in $5 \mathrm{~mL}$ of dichloromethane and dripped into $150 \mathrm{~mL}$ hexanes. The precipitate was aged for one hour, collected by gravity filtration, and dried in vacuo to yield a colorless salt $(55.6 \%, 431.7$ $\mathrm{mg}) .{ }^{1} \mathrm{H}$ NMR $\left(\mathrm{CD}_{3} \mathrm{CN}, 400 \mathrm{MHz}, 25^{\circ} \mathrm{C}\right): \delta 8.01(\mathrm{~d}, \mathrm{~J}=9.2 \mathrm{~Hz}, 2 \mathrm{H}), 7.25(\mathrm{~s}, 1 \mathrm{H}), 7.07(\mathrm{~d}, \mathrm{~J}=$ $9.2 \mathrm{~Hz}, 2 \mathrm{H}), 6.81(\mathrm{dd}, \mathrm{J}=7.8,1.8 \mathrm{~Hz}, 1 \mathrm{H}), 6.62$ (dd, J = 7.9, $1.9 \mathrm{~Hz}, 1 \mathrm{H}), 6.29$ (dd, J = 7.9, 1.6 $\mathrm{Hz}, 1 \mathrm{H}), 6.12(\mathrm{dd}, \mathrm{J}=8.0,2.0 \mathrm{~Hz}, 1 \mathrm{H}), 6.02(\mathrm{~s}, 1 \mathrm{H}), 3.83(\mathrm{~s}, 3 \mathrm{H}), 3.74(\mathrm{~s}, 3 \mathrm{H}), 3.31$ (ddd, J = 
11.6, 9.8, 1.7 Hz, 1 H), 3.26 (dd, J = 8.4, $5.7 \mathrm{~Hz}, 1 \mathrm{H}), 3.23$ (dd, J = 13.9, $4.3 \mathrm{~Hz}, 1 \mathrm{H}), 3.18$ (dd, $\mathrm{J}=12.9,4.1 \mathrm{~Hz}, 1 \mathrm{H}), 3.15(\mathrm{dd}, \mathrm{J}=8.3,3.0 \mathrm{~Hz}, 1 \mathrm{H}), 3.05(\mathrm{ddd}, \mathrm{J}=12.8,9.9,6.4 \mathrm{~Hz}, 1 \mathrm{H}), 3.02$ $(\mathrm{ddd}, \mathrm{J}=12.8,9.9,6.4 \mathrm{~Hz}, 1 \mathrm{H}), 2.68(\mathrm{ddd}, \mathrm{J}=13.1,10.5,6.4 \mathrm{~Hz}, 1 \mathrm{H}) .{ }^{13} \mathrm{C} \mathrm{NMR}\left(\mathrm{CD}_{3} \mathrm{CN}, 100\right.$ $\left.\mathrm{MHz}, 25{ }^{\circ} \mathrm{C}\right): \delta 163.3,161.6,146.4,140.5,139.9,137.9,137.4,133.2,132.4,131.4,131.3$, $128.8,119.8,118.2,107.4,101.1,55.8,54.9,37.2,34.5,32.9,30.7 .{ }^{19} \mathrm{~F}$ NMR $\left(\mathrm{CD}_{3} \mathrm{CN}, 376\right.$ $\left.\mathrm{MHz}, 25{ }^{\circ} \mathrm{C}\right): \delta-72.7(\mathrm{~d}, \mathrm{~J}=706.7 \mathrm{~Hz}, 6 \mathrm{~F})$. HRMS: (HRFAB) calcd. for $\mathrm{C}_{24} \mathrm{H}_{24} \mathrm{IO}_{2}[\mathrm{M}]^{+}$ 471.08210, 472.08454; found 471.08221, 472.08561.

Fluorination of $\mathbf{2}\left(\mathbf{P F}_{\mathbf{6}}\right)$ : In a $\mathrm{N}_{2}$ charged glove box, $12.3 \mathrm{mg} \mathbf{2}\left(\mathbf{P F}_{\mathbf{6}}\right)(0.02 \mathrm{mmol})$ was dissolved in $0.3 \mathrm{~mL}$ of dry acetonitrile, to which a solution of $1 \mathrm{mg}$ anhydrous TMAF (1 equivalent ) in 0.3 $\mathrm{mL}$ of dry acetonitrile was added dropwise. The solvent was evaporated, and the remainder was dissolved in $0.6 \mathrm{~mL}$ of $d_{6}$-benzene, passed through a $0.2 \mu \mathrm{m}$ PTFE syringe filter, and transferred into a J-Young NMR tube. The tube was sealed, taken out of the box, and heated in a $140{ }^{\circ} \mathrm{C}$ oil bath for 15 minutes*. Yields of fluorinated arenes were determined by ${ }^{1} \mathrm{H}$ and ${ }^{19} \mathrm{~F}$ NMR spectroscopy and confirmed by GC-MS. 4-fluoro-7-methoxy[2.2]paracyclophane in 26\% yield, 4-fluoro-8-methoxy[2,2]paracyclophane in 29\% yield (in GC-MS, these two fluorocyclophane species appear to be equal amount), 4-fluoroanisole was formed in 30\% yield, 3-fluoroanisole in $6.5 \%$ yield, the rest of the fluoride ended up as unidentified inorganic species (singlets in ${ }^{19} \mathrm{~F}$ NMR).

Decomposition was also performed at $80{ }^{\circ} \mathrm{C}$, the reaction took 3 hours to finish, and the product ratios were similar to the reaction done at $140{ }^{\circ} \mathrm{C}$.

(5-Methoxy[2.2]paracyclophan-4-yl)(4-methoxyphenyl)iodonium hexafluorophosphate, $3\left(\mathrm{PF}_{6}\right)$

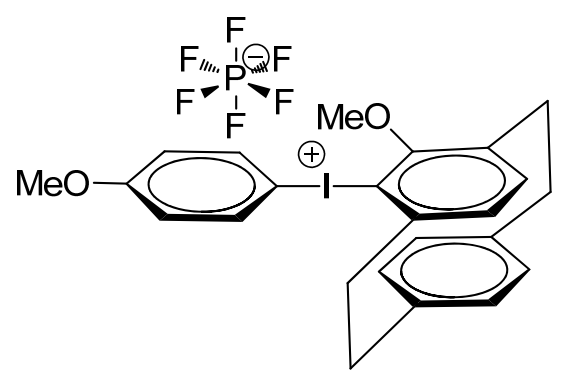

In a $100 \mathrm{~mL}$ Schlenk tube, 4-methoxy-5-iodo-[2.2]paracyclophane (416.7 $\mathrm{mg}, 1.14 \mathrm{mmol}$ ) was dissolved in $25 \mathrm{~mL}$ of distilled $\mathrm{Et}_{2} \mathrm{O}$ and cooled to $-78^{\circ} \mathrm{C}$. To this stirred solution, $1.7 \mathrm{M}$-butyl lithium $(1.68 \mathrm{~mL}, 2.85 \mathrm{mmol})$ was added dropwise and the solution was held at $-78{ }^{\circ} \mathrm{C}$ for $1 \mathrm{~h}$. A solution of anhydrous zinc chloride $(1.37 \mathrm{mmol}, 190.0 \mathrm{mg})$ in $10 \mathrm{~mL}$ of $\mathrm{Et}_{2} \mathrm{O}$ was added dropwise to the cold solution over the course of $1 \mathrm{~h}$. The mixture was allowed to warm to room temperature, and the solvent was removed under reduced pressure. The residual solid (comprising organozinc chloride reagent and lithium salts) was taken up in anhydrous acetonitrile and cooled to $-40{ }^{\circ} \mathrm{C}$ before a solution of 4-methoxyphenyliodonium diacetate (1.89 $\mathrm{mmol}, 665.5 \mathrm{mg})$ in acetonitrile $(10 \mathrm{~mL})$ was added in a dropwise fashion. The mixture was held at $-40{ }^{\circ} \mathrm{C}$ for $1 \mathrm{~h}$ and allowed to warm to room temperature. The solvent was removed under reduced pressure, and, in order, deionized water, sodium hexafluorophosphate (470 mg), and 50 $\mathrm{mL}$ of $\mathrm{CH}_{2} \mathrm{Cl}_{2}$ were added. The mixture was transferred to a separatory funnel and the organic phase was separated. The solvent was removed by rotary evaporation and the remaining solid was dissolved in $5 \mathrm{~mL}$ of dichloromethane and dripped into $150 \mathrm{~mL}$ hexanes. The precipitate was aged for $1 \mathrm{~h}$, collected by gravity filtration, and dried in vacuo to yield a colorless salt (91.0 mg, $13.0 \%$ \%). ${ }^{1} \mathrm{H}$ NMR $\left(\mathrm{CD}_{3} \mathrm{CN}, 400 \mathrm{MHz}, 25{ }^{\circ} \mathrm{C}\right): \delta 7.99$ (d, $\left.9.3 \mathrm{~Hz}, 2 \mathrm{H}\right), 7.07$ (d, $\left.9.2 \mathrm{~Hz}, 2 \mathrm{H}\right)$, 
$6.84(\mathrm{~d}, 7.8 \mathrm{~Hz}, 1 \mathrm{H}), 6.59-6.69(\mathrm{~m}, 4 \mathrm{H}), 6.11(\mathrm{~d}, 7.9 \mathrm{~Hz}, 1 \mathrm{H}), 3.88(\mathrm{~s}, 3 \mathrm{H}), 3.84(\mathrm{~s}, 3 \mathrm{H}), 3.32-$ $3.38(\mathrm{~m}, 1 \mathrm{H}), 3.06-3.26(\mathrm{~m}, 6 \mathrm{H}), 2.93-3.00(\mathrm{~m}, 1 \mathrm{H}) .{ }^{13} \mathrm{C} \mathrm{NMR}\left(\mathrm{CD}_{3} \mathrm{CN}, 400 \mathrm{MHz}, 25{ }^{\circ} \mathrm{C}\right): \delta$ $163.4,156.9,144.9,142.3,140.0,138.3,138.2,133.7,133.3,133.2,131.8,130.4,129.2,118.3$, 99.3, 62.5, 55.8, 36.9, 33.8, 33.7, 31.9. ${ }^{19} \mathrm{~F} \mathrm{NMR}\left(\mathrm{CD}_{3} \mathrm{CN}, 400 \mathrm{MHz}, 25{ }^{\circ} \mathrm{C}\right): \delta-72.8(\mathrm{~d}, \mathrm{~J}=$ $706.9 \mathrm{~Hz}, 6 \mathrm{~F})$. HRMS: (HRFAB) calcd. for $\mathrm{C}_{24} \mathrm{H}_{24} \mathrm{IO}_{2}[\mathrm{M}]^{+} 471.0821$, found 471.0806 .

Fluorination of $\mathbf{3}\left(\mathbf{P F}_{\mathbf{6}}\right)$ : In a $\mathrm{N}_{2}$ charged glove box, $12.3 \mathrm{mg} \mathbf{3}\left(\mathbf{P F}_{\mathbf{6}}\right)$ (0.02 mmol) was dissolved in $0.3 \mathrm{~mL}$ of dry acetonitrile, to which a solution of $1 \mathrm{mg}$ anhydrous TMAF (1 equivalent ) in 0.3 $\mathrm{mL}$ of dry acetonitrile was added dropwise. The solvent was evaporated, and the remainder was dissolved in $0.6 \mathrm{~mL}$ of $d_{6}$-benzene, passed through a $0.2 \mu \mathrm{m}$ PTFE syringe filter, and transferred into a J-Young NMR tube. The tube was sealed, taken out of the box, and heated in a $140{ }^{\circ} \mathrm{C}$ oil bath for 15 minutes*. Yields of fluorinated arenes were determined by ${ }^{1} \mathrm{H}$ and ${ }^{19} \mathrm{~F}$ NMR spectroscopy and confirmed by GC-MS. 4-fluoroanisole was formed in $72 \%$ yield, 3fluoroanisole in $15 \%$ yield, the rest of the fluoride ended up as unidentified inorganic species (singlet at -128.1 ppm and multiplets at $-130.7 \mathrm{ppm}$ in ${ }^{19} \mathrm{~F} \mathrm{NMR}$ ).

For this salt, decomposition was also performed at $80{ }^{\circ} \mathrm{C}$, the reaction took 6 hours to finish and 4-fluoroanisole was formed in $81 \%$ yield, 3-fluoroanisole in $9 \%$ yield. (Unidentified inorganic species were also present.)

\section{Synthesis of model diaryliodonium salts:}

\section{Bis(4-methoxyphenyl)iodonium hexafluorophosphate, $4\left(\mathrm{PF}_{6}\right)$}

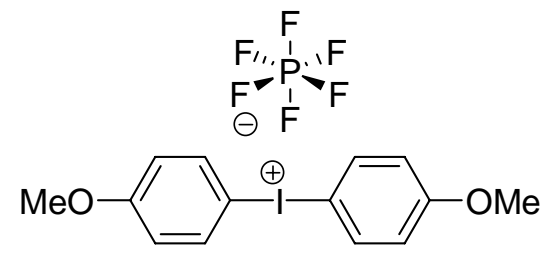

In a glove box under nitrogen, 1-(diacetoxyiodo)-4-methoxybenzene (352 $\mathrm{mg}, 1 \mathrm{mmol}$ ) was weighed into a glass vial and $1.5 \mathrm{~mL}$ of dry acetonitrile was added. A solution containing $p$ toluenesulfonic acid monohydrate $(190 \mathrm{mg}, 1 \mathrm{mmol})$ dissolved in $1.5 \mathrm{~mL}$ of dry acetonitrile was added by syringe. Upon completion of the addition, 4-iodoanisole (neat, $0.11 \mathrm{~mL}, 1 \mathrm{mmol}$ ) was added and the vial was sealed and taken out of the glove box; the mixture was allowed to stir at room temperature for $2 \mathrm{~h}$. Water $(10 \mathrm{~mL})$ was added and the mixture was transferred to a separatory funnel and extracted $(3 \times 5 \mathrm{~mL})$ with hexanes. The reserved aqueous layer was treated with $502 \mathrm{mg}(3 \mathrm{mmol})$ of $\mathrm{NaPF}_{6}$. The white precipitate was filtered, dried in vacuo, and recrystallized in a mixture of diethyl ether/dichloromethane to give $391 \mathrm{mg}$ of bis(4methoxyphenyl)iodonium hexafluorophosphate (80.5\%). ${ }^{1} \mathrm{H} \mathrm{NMR}\left(\mathrm{CD}_{3} \mathrm{CN}, 400 \mathrm{MHz}, 25{ }^{\circ} \mathrm{C}\right): \delta$ 7.973 (d, J = 9.1 Hz, 4H, H2/H2'/H6/H6'), 7.046 (d, J = 9.1 Hz, 4H, H3/H3'/H5/H5'), 3.833 (s, $6 \mathrm{H}, \mathrm{OMe}) ;{ }^{13} \mathrm{C} \mathrm{NMR}\left(\mathrm{CD}_{3} \mathrm{CN}, 100 \mathrm{MHz}, 25^{\circ} \mathrm{C}\right) \delta 164.61$ (C4/C4'), 138.55 (C2/C2'/C6/C6'), 119.42 (C3/C3'/C5/C5'), 103.36 (C1/C1'), 57.06 (OMe); ${ }^{19} \mathrm{~F} \mathrm{NMR}\left(\mathrm{CD}_{3} \mathrm{CN}, 376 \mathrm{MHz}, 25^{\circ} \mathrm{C}\right) \delta$ $-72.833\left(\mathrm{~d},{ }^{1} \mathrm{~J}_{\mathrm{P}-\mathrm{F}}=707.3 \mathrm{~Hz}, \mathrm{PF}_{6}{ }^{-}\right)$; HRMS (HRFAB): calcd. for $\mathrm{C}_{14} \mathrm{H}_{14} \mathrm{O}_{2} \mathrm{I}\left[\mathrm{M}-\mathrm{PF}_{6}\right]^{+} 341.0038$ found 341.0036 .

\section{(2-Methoxyphenyl)(4-methoxyphenyl)iodonium hexafluorophosphate 5( $\left.\mathrm{PF}_{6}\right)$}




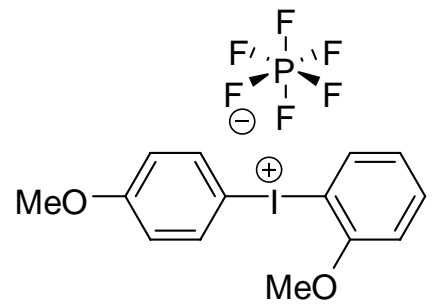

In a glove box under nitrogen, 1-(diacetoxyiodo)-2-methoxybenzene (352 $\mathrm{mg}, 1 \mathrm{mmol}$ ) was weighed into a glass vial and $1.5 \mathrm{~mL}$ of dry acetonitrile was added. A solution containing $p$ toluenesulfonic acid monohydrate $(190 \mathrm{mg}, 1 \mathrm{mmol})$ dissolved in $1.5 \mathrm{~mL}$ of dry acetonitrile was added by syringe. Upon completion of the addition, 4-iodoanisole (neat, $0.11 \mathrm{~mL}, 1 \mathrm{mmol}$ ) was added. The vial was sealed and taken out of the glove box; the mixture was allowed to stir at room temperature for $2 \mathrm{~h}$. Water $(10 \mathrm{~mL})$ was added and the mixture was transferred to a separatory funnel and extracted $(3 \times 5 \mathrm{~mL})$ with hexanes. The reserved aqueous layer was treated with $502 \mathrm{mg}(3 \mathrm{mmol})$ of $\mathrm{NaPF}_{6}$. The white precipitate was filtered, dried in vacuo, and recrystallized in a mixture of diethyl ether/dichloromethane to give $405 \mathrm{mg}(83.3 \%)$ of (2methoxyphenyl)-(4'-methoxyphenyl)iodonium hexafluorophosphate. ${ }^{1} \mathrm{H}$ NMR $\left(\mathrm{CD}_{3} \mathrm{CN}, 400\right.$ $\left.\mathrm{MHz}, 25^{\circ} \mathrm{C}\right): \delta 7.988\left(\mathrm{~d}, \mathrm{~J}=9.2 \mathrm{~Hz}, 2 \mathrm{H}, \mathrm{H} 2^{\prime} / \mathrm{H} 6\right.$ ') $7.878(\mathrm{~d}, \mathrm{~J}=8.4 \mathrm{~Hz}, 1 \mathrm{H}, \mathrm{H} 6), 7.659\left(\mathrm{td}, \mathrm{J}_{1}=\right.$ $\left.8.4 \mathrm{~Hz}, \mathrm{~J}_{2}=1.3 \mathrm{~Hz}, 1 \mathrm{H}, \mathrm{H} 4\right), 7.232\left(\mathrm{dd}, \mathrm{J}_{1}=8.4 \mathrm{~Hz}, \mathrm{~J}_{2}=1.3 \mathrm{~Hz}, 1 \mathrm{H}, \mathrm{H} 5\right), 7.063\left(\mathrm{td}, \mathrm{J}_{1}=8.4 \mathrm{~Hz}\right.$, $\left.\mathrm{J}_{2}=1.3 \mathrm{~Hz}, 1 \mathrm{H}, \mathrm{H} 3\right), 7.051$ (d, J = 9.2, 2H, H3'/H5'), 3.970 (s, 3H, 2-OMe), 3.841 (s, 3H, 4' $\mathrm{OMe}) ;{ }^{13} \mathrm{C} \mathrm{NMR}\left(\mathrm{CD}_{3} \mathrm{CN}, 100 \mathrm{MHz}, 25{ }^{\circ} \mathrm{C}\right) \delta 164.73$ (C4'), 157.90 (C2), 139.52 (C2'/C6'), 137.08 (C4), 136.79 (C6), 125.36 (C3), 119.44 (C3'/C5'), 114.70 (C5), 104.69 (C1), 100.92 (C1'), 58.40 (2-OMe), 57.06 (4'-OMe); ${ }^{\prime}{ }^{\prime} \mathrm{F} \mathrm{NMR}\left(\mathrm{CD}_{3} \mathrm{CN}, 376 \mathrm{MHz}, 25^{\circ} \mathrm{C}\right) \delta-72.675\left(\mathrm{~d},{ }^{1} \mathrm{~J}_{\mathrm{P}-\mathrm{F}}\right.$ $=706.2 \mathrm{~Hz}, \mathrm{PF}_{6}{ }^{-}$); HRMS (HRFAB): calcd. for $\mathrm{C}_{14} \mathrm{H}_{14} \mathrm{O}_{2} \mathrm{I}\left[\mathrm{M}-\mathrm{PF}_{6}\right]^{+} 341.0038$ found 341.0035 .

\section{Synthesis of precursors:}

\section{Bis(acetyloxy)-(4-methoxyphenyl)- $\lambda_{3}$-iodane; (1-(diacetoxyiodo)-4-methoxybenzene<smiles>COc1ccc(OC(C)=O)cc1</smiles>

4-Iodoanisole (2.34 g, $10 \mathrm{mmol})$ was dissolved in $90 \mathrm{~mL}$ of glacial acetic acid and the stirred solution was warmed to $40{ }^{\circ} \mathrm{C}$. Sodium perborate tetrahydrate $(13.6 \mathrm{~g}, 110 \mathrm{mmol})$ was added in portions over the course of one hour. After the addition was complete, the temperature of the reaction mixture was maintained at $40{ }^{\circ} \mathrm{C}$ for $8 \mathrm{~h}$ before it was allowed to cool to room temperature. Half of the acetic acid $(\sim 45 \mathrm{~mL})$ was removed by distillation at reduced pressure. The remaining solution was treated with $100 \mathrm{~mL}$ of deionized water and the aqueous layer was extracted $(3 \times 40 \mathrm{~mL})$ with dichloromethane. The combined organic fractions were dried over sodium sulfate, and the solvent was removed by rotary evaporation to give $2.25 \mathrm{~g}(64 \%)$ of 1 (diacetoxyiodo)-4-methoxybenzene, 1a. This compound was dried in vacuo and used without further purification. ${ }^{1} \mathrm{H} \mathrm{NMR}\left(\mathrm{CD}_{3} \mathrm{CN}, 400 \mathrm{MHz}, 25^{\circ} \mathrm{C}\right): \delta 8.055(\mathrm{~d}, \mathrm{~J}=9.1 \mathrm{~Hz}, 2 \mathrm{H}, \mathrm{H} 2 / \mathrm{H} 6)$, $7.053(\mathrm{~d}, \mathrm{~J}=9.1 \mathrm{~Hz}, 2 \mathrm{H}, \mathrm{H} 3 / \mathrm{H} 5), 3.861$ (s, 3H, OMe), $1.905\left(\mathrm{~s}, 6 \mathrm{H},\left(\mathrm{OCOCH}_{3}\right)_{2}\right) ;{ }^{13} \mathrm{C} \mathrm{NMR}$ $\left(\mathrm{CD}_{3} \mathrm{CN}, 100 \mathrm{MHz}, 25{ }^{\circ} \mathrm{C}\right) \delta 177.73(\mathrm{CO}), 163.73(\mathrm{C} 4), 138.75$ (C2/C6), 118.00, (C3/C5), $111.97(\mathrm{C} 1), 56.85(\mathrm{OMe}), 20.76\left(\left(\mathrm{OCOCH}_{3}\right)_{2}\right)$; HRMS: (HRFAB) calcd. for $\mathrm{C}_{14} \mathrm{H}_{13} \mathrm{NO}_{4} \mathrm{I}[\mathrm{M}-$ $2 \mathrm{OAc}+3-\mathrm{NBA}]^{+} 385.9889$ found 385.9885. (lit. ${ }^{3,4}{ }^{13} \mathrm{C} \mathrm{NMR}\left(\mathrm{CDCl}_{3}, 50 \mathrm{MHz}, 20{ }^{\circ} \mathrm{C}\right) \delta 162.0$ 
(C4), 137.0 (C2/C6), 116.5 (C3/C5), $111.4(\mathrm{C} 1).) ;{ }^{13} \mathrm{C} \mathrm{NMR}\left(\mathrm{CDCl}_{3}, 75 \mathrm{MHz}, 25{ }^{\circ} \mathrm{C}\right) \delta 176.31$ (CO), $111.64(\mathrm{C} 1), 20.36\left(\left(\mathrm{OCOCH}_{3}\right)_{2}\right)$.)

\section{Bis(acetyloxy)-(2-methoxyphenyl)- $\lambda_{3}$-iodane; (1-(diacetoxyiodo)-2-methoxybenzene}<smiles>COc1ccccc1I(OC(C)=O)OC(C)=O</smiles>

2-Iodoanisole (2.34 g, $10 \mathrm{mmol})$ was dissolved in $90 \mathrm{~mL}$ of glacial acetic acid and the stirred solution was warmed to $40{ }^{\circ} \mathrm{C}$. Sodium perborate tetrahydrate $(13.6 \mathrm{~g}, 110 \mathrm{mmol})$ was added in portions over the course of one hour. After the addition was complete, the temperature of the reaction mixture was maintained at $40{ }^{\circ} \mathrm{C}$ for $8 \mathrm{~h}$ before it was allowed to cool to room temperature. Half of the acetic acid $(\sim 45 \mathrm{~mL})$ was removed by distillation at reduced pressure. The remaining solution was treated with $100 \mathrm{~mL}$ of deionized water and the aqueous layer was extracted $(3 \times 40 \mathrm{~mL})$ with dichloromethane. The combined organic fractions were dried over sodium sulfate, and the solvent was removed by rotary evaporation to give $2.29 \mathrm{~g}(65 \%)$ of 1 (diacetoxyiodo)-2-methoxybenzene. This compound was dried in vacuo and used without further purification. ${ }^{1} \mathrm{H} \mathrm{NMR}\left(\mathrm{CD}_{3} \mathrm{CN}, 400 \mathrm{MHz}, 25^{\circ} \mathrm{C}\right): \delta 8.175(\mathrm{~d}, \mathrm{~J}=8.0 \mathrm{~Hz}, 1 \mathrm{H}, \mathrm{H} 6), 7.690\left(\mathrm{dd}, \mathrm{J}_{1}\right.$ = 7.6, $\left.\mathrm{J}_{2}=8.2 \mathrm{~Hz} 1 \mathrm{H}, \mathrm{H} 5\right), 7.313(\mathrm{~d}, \mathrm{~J}=8.2 \mathrm{~Hz}, 1 \mathrm{H}, \mathrm{H} 3), 7.085$ (dd, $\left.\mathrm{J}_{1}=8.0, \mathrm{~J}_{2}=7.6 \mathrm{~Hz}, 1 \mathrm{H}, \mathrm{H} 4\right)$, $3.958(\mathrm{~s}, 3 \mathrm{H}, \mathrm{OMe}), 1.884\left(\mathrm{~s}, 6 \mathrm{H},\left(\mathrm{OCOCH}_{3}\right)_{2}\right) ;{ }^{13} \mathrm{C} \mathrm{NMR}\left(\mathrm{CD}_{3} \mathrm{CN}, 100 \mathrm{MHz}, 25{ }^{\circ} \mathrm{C}\right) \delta 178.00$ (CO), 157.72(C2), 139.09 (C6), 136.34 (C4), 124.17 (C3), 113.91 (C1), 113.87 (C5), 58.20 $(\mathrm{OMe}), 20.71\left(\left(\mathrm{OCOCH}_{3}\right)_{2}\right)$; HRMS (HRFAB): calcd. for $\mathrm{C}_{14} \mathrm{H}_{13} \mathrm{NO}_{4} \mathrm{I}[\mathrm{M}-2 \mathrm{OAc}+3-\mathrm{NBA}]^{+}$ 385.9889 found 385.9874. (lit. ${ }^{5} \mathrm{H}$ NMR $\delta\left(270 \mathrm{MHz}, \mathrm{CDCl}_{3}\right) 8.10(1 \mathrm{H}, \mathrm{d}, \mathrm{H} 6 \mathrm{~J}=8 \mathrm{~Hz}), 7.56$ $(1 \mathrm{H}, \mathrm{t}, \mathrm{H} 5 \mathrm{~J}=8 \mathrm{~Hz}), 7.13(1 \mathrm{H}, \mathrm{d}, \mathrm{H} 3, \mathrm{~J}=8 \mathrm{~Hz}), 7.00(1 \mathrm{H}, \mathrm{t}, \mathrm{H} 4 \mathrm{~J}=8 \mathrm{~Hz}), 3.95\left(3 \mathrm{H}, \mathrm{s}, \mathrm{OCH}_{3}\right)$, $1.93\left(6 \mathrm{H}, \mathrm{s},\left(\mathrm{OCOCH}_{3}\right)_{2}\right) ;{ }^{13} \mathrm{C} \mathrm{NMR}\left(68 \mathrm{MHz} ; \mathrm{CDCl}_{3}\right) \delta 176.7(\mathrm{CO}), 156.3(\mathrm{C} 3), 137.8,134.6$, 122.9, $\left.113.4(\mathrm{C} 1), 112.1,57.0(\mathrm{OMe}), 20.5\left(\left(\mathrm{OCOCH}_{3}\right)_{2}\right).\right)$

\section{4-Bromo-[2.2]paracyclophane, ${ }^{6} 6$}

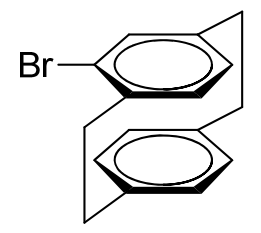

N-Bromosuccinimide $(890.1 \mathrm{mg}, 5.0 \mathrm{mmol})$ and trifluoroacetic acid $(570 \mathrm{mg}, 0.385 \mathrm{~mL}, 5.0$ mmol) were dissolved in $40 \mathrm{~mL}$ of dichloromethane and added to a $\mathrm{CH}_{2} \mathrm{Cl}_{2}$ solution $(80 \mathrm{~mL})$ of [2.2]paracyclophane $(1.0297 \mathrm{~g}, 4.9 \mathrm{mmol})$. The resulting mixture was covered from light and stirred for 4 hours at room temperature. The solution was transferred to a separatory funnel and washed $(3 \times 50 \mathrm{~mL})$ with $2 \mathrm{M}$ aqueous sodium bicarbonate solution followed by a single deionized water wash. The organic layer was separated, dried over $\mathrm{Na}_{2} \mathrm{SO}_{4}$, and the solvent was evaporated to give a nearly colorless solid $(1.061 \mathrm{~g}, 75 \%)$ that was sufficiently pure to carry forward in the synthesis. ${ }^{1} \mathrm{H} \mathrm{NMR}\left(\mathrm{CDCl}_{3}, 400 \mathrm{MHz}, 25^{\circ} \mathrm{C}\right): \delta 7.18(\mathrm{dd}, \mathrm{J}=7.8,1.9 \mathrm{~Hz}, 1 \mathrm{H})$, 6.45-6.61 (m, $6 \mathrm{H}), 3.45-3.52(\mathrm{~m}, 1 \mathrm{H}), 2.80-3.26(\mathrm{~m}, 7 \mathrm{H}) ;{ }^{13} \mathrm{C} \mathrm{NMR}\left(\mathrm{CDCl}_{3}, 100 \mathrm{MHz}, 25{ }^{\circ} \mathrm{C}\right)$ $\delta$ 141.61, 139.33, 139.11, 137.25, 135.05, 133.31, 133.02, 132.91, 132.25, 131.46, 128.69, $126.97,35.85,35.48,34.82,33.47$. 


\section{4-Hydroxy[2.2]paracyclophane, ${ }^{7} 7$}

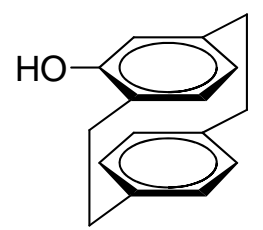

In a $50 \mathrm{~mL}$ Schlenk tube under nitrogen, a stirred, cold $\left(-78^{\circ} \mathrm{C}\right)$ solution of 4bromo[2.2]paracyclophane $(4.0 \mathrm{mmol}, 1.14 \mathrm{~g})$ in $50 \mathrm{~mL}$ of anhydrous diethyl ether was treated with t-BuLi (1.7 $\mathrm{M}$ in pentane, 2.5 equiv., added dropwise). The resulting mixture was stirred at $78{ }^{\circ} \mathrm{C}$ for $20 \mathrm{~min}$ and held subsequently at $0^{\circ} \mathrm{C}$ for $20 \mathrm{~min}$. To this heterogeneous yellow mixture trimethyl borate $(0.89 \mathrm{~mL}, 8.0 \mathrm{mmol})$ was added dropwise by syringe and the mixture was stirred for $1 \mathrm{~h}$ at room temperature. During this period the solution became homogeneous and dark yellow. When the reaction was quenched with aqueous $\mathrm{NaOH}(0.5 \mathrm{M}, 2 \mathrm{~mL})$ and $\mathrm{H}_{2} \mathrm{O}_{2}(30 \%$, $1.5 \mathrm{~mL}$ ), a slight exotherm and gas evolution were noted. The resulting mixture was allowed to stir overnight at room temperature. Additional aqueous $\mathrm{NaOH}$ solution $(0.5 \mathrm{M}, 5 \mathrm{~mL})$ was added and the $\mathrm{pH}$ of the solution was adjusted to neutral using saturated sodium bicarbonate solution and $1 \mathrm{M} \mathrm{HCl}$. The mixture was extracted $(3 \times 20 \mathrm{~mL})$ with diethyl ether. The combined ether extracts were washed with $0.5 \mathrm{M}$ sodium bisulfite, and the organic layers was separated and dried over $\mathrm{Na}_{2} \mathrm{SO}_{4}$. Removal of the solvent by rotary evaporation gave a light brown solid (844.1 mg, 94.1\%). ${ }^{1} \mathrm{H}$ NMR $\left(\mathrm{CDCl}_{3}, 400 \mathrm{MHz}, 25{ }^{\circ} \mathrm{C}\right): \delta 7.01(\mathrm{dd}, \mathrm{J}=7.8,1.9 \mathrm{~Hz}, 1 \mathrm{H}), 6.56(\mathrm{dd}, \mathrm{J}=$ 7.8, $1.9 \mathrm{~Hz}, 1 \mathrm{H}), 6.46(\mathrm{dd}, \mathrm{J}=7.8,1.9 \mathrm{~Hz}, 1 \mathrm{H}), 6.38-6.42(\mathrm{~m}, 2 \mathrm{H}), 6.27(\mathrm{dd}, \mathrm{J}=7.7,1.6 \mathrm{~Hz}, 1$ $\mathrm{H}), 5.55(\mathrm{~d}, \mathrm{~J}=1.6 \mathrm{~Hz}, 1 \mathrm{H}), 3.29-3.39(\mathrm{~m}, 1 \mathrm{H}), 2.87-3.16(\mathrm{~m}, 6 \mathrm{H}), 2.62-2.73(\mathrm{~m}, 1 \mathrm{H}) .{ }^{13} \mathrm{C}$ NMR $\left(\mathrm{CDCl}_{3}, 100 \mathrm{MHz}, 25^{\circ} \mathrm{C}\right): \delta 153.7,142.0,139.6,138.8,135.5,133.0,132.8,131.9,127.9$, $125.4,125.0,122.6,35.3,34.8,33.8,31.1$.

\section{4-Methoxy[2.2]paracyclophane, ${ }^{6} 8$}

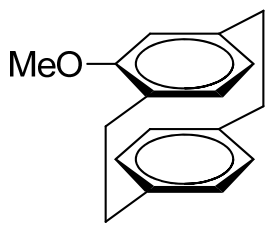

In a $100 \mathrm{~mL}$ glass tube sealed with a Teflon screw cap closure, potassium carbonate $(1.66 \mathrm{~g}, 12$ $\mathrm{mmol}$ ) and 4-hydroxy[2.2]paracyclophane ( $869.6 \mathrm{mg}, 3.87 \mathrm{mmol})$ were heated to $80{ }^{\circ} \mathrm{C}$ in $60 \mathrm{~mL}$ of acetonitrile for 30 minutes. Iodomethane $(1.7 \mathrm{~g}, 12 \mathrm{mmol})$ was added to the mixture, the storage tube was sealed, and the stirred solution was heated at $80{ }^{\circ} \mathrm{C}$ for 3 days. The solvent was removed by rotary evaporation and the remaining solid was treated with ethyl acetate and water and transferred to a separatory funnel. The aqueous layer was neutralized with $0.1 \mathrm{M} \mathrm{HCl}$ solution, the mixture was shaken, and the organic layer was separated and dried over $\mathrm{Na}_{2} \mathrm{SO}_{4}$. Rotary evaporation of solvent yielded a nearly colorless solid. The somewhat insoluble material was dissolved in hot hexanes and purified via column chromatography ( $60 \AA$ silica gel, hexanes, $\left.\mathrm{R}_{\mathrm{f}}=0.28\right)$ to afford a colorless solid $(602.4 \mathrm{mg}, 65.4 \%) .{ }^{1} \mathrm{H} \mathrm{NMR}\left(\mathrm{CDCl}_{3}, 400 \mathrm{MHz}, 25{ }^{\circ} \mathrm{C}\right): \delta$ $6.76(\mathrm{dd}, \mathrm{J}=7.8,1.8 \mathrm{~Hz}, 1 \mathrm{H}), 6.38-6.55(\mathrm{~m}, 4 \mathrm{H}), 6.28(\mathrm{dd}, \mathrm{J}=7.5,1.4 \mathrm{~Hz}, 1 \mathrm{H}), 5.67(\mathrm{~d}, \mathrm{~J}=$ 1.3, $1 \mathrm{H}), 3.71(\mathrm{~s}, 3 \mathrm{H}), 3.42-3.48(\mathrm{~m}, 1 \mathrm{H}), 2.99-3.13(\mathrm{~m}, 6 \mathrm{H}), 2.59-2.66(\mathrm{~m}, 1 \mathrm{H}) .{ }^{13} \mathrm{C}$ NMR $\left(\mathrm{CDCl}_{3}, 100 \mathrm{MHz}, 25^{\circ} \mathrm{C}\right): \delta 157.6,142.1,140.3,138.8,135.0,133.7,133.1,131.5,128.4$, $127.5,124.4,116.7,54.3,35.5,35.4,34.1,31.7$. 


\section{4-Methoxy-7-bromo[2.2]paracyclophane, ${ }^{8} 9$}

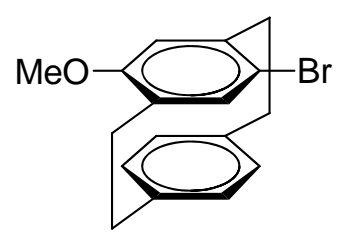

To a solution of 4-methoxy[2.2]paracyclophane $(349.7 \mathrm{~g}, 1.47 \mathrm{mmol})$ in $30 \mathrm{~mL} \mathrm{CH}_{2} \mathrm{Cl}_{2}$, was added N-bromosuccinimide $(279.4 \mathrm{mg}, 1.57 \mathrm{mmol})$ and trifluoroacetic acid $(179.0 \mathrm{mg}, 0.12 \mathrm{~mL}$, $1.57 \mathrm{mmol}$ ) dissolved in $15 \mathrm{~mL}$ of $\mathrm{CH}_{2} \mathrm{Cl}_{2}$. The resulting mixture was covered from light and stirred for 30 minutes at room temperature. The solution was transferred to a separatory funnel and washed $(3 \times 50 \mathrm{~mL})$ with $2 \mathrm{M}$ aqueous sodium bicarbonate solution followed by deionized water. The organic layer was separated, dried over $\mathrm{Na}_{2} \mathrm{SO}_{4}$, and the solvent was evaporated. The resulted light brown solid was purified by column chromatography (60 $\AA$ silica gel, hexanes) to give the product as a pale yellow solid (400.6 mg, $86 \%)$. ${ }^{1} \mathrm{H} \mathrm{NMR}\left(\mathrm{CDCl}_{3}, 400 \mathrm{MHz}, 25{ }^{\circ} \mathrm{C}\right): \delta$ $7.10(\mathrm{dd}, \mathrm{J}=7.8,1.8 \mathrm{~Hz}, 1 \mathrm{H}), 6.76(\mathrm{dd}, \mathrm{J}=7.9,1.9 \mathrm{~Hz}, 1 \mathrm{H}), 6.41-6.46(\mathrm{~m}, 3 \mathrm{H}), 5.69$ (s, $1 \mathrm{H})$, $3.71(\mathrm{~s}, 3 \mathrm{H}), 3.34-3.45(\mathrm{~m}, 2 \mathrm{H}), 3.18-3.25(\mathrm{~m}, 1 \mathrm{H}), 2.98-3.10(\mathrm{~m}, 3 \mathrm{H}), 2.71-2.78(\mathrm{~m}, 1$ $\mathrm{H}), 2.46-2.54(\mathrm{~m}, 1 \mathrm{H}) ;{ }^{13} \mathrm{C} \mathrm{NMR}\left(\mathrm{CDCl}_{3}, 100 \mathrm{MHz}, 25{ }^{\circ} \mathrm{C}\right) \delta 157.15,140.81,139.95,138.76$, $138.65,133.19,133.16,131.83,130.00,129.19,118.54,117.26,54.69,35.89,33.82,33.51$, 31.29 .

\section{4-Diethylcarbamoyl[2.2]paracyclophane, ${ }^{9} 10$}

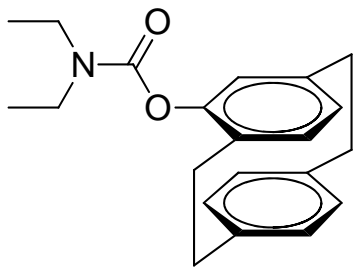

In a $250 \mathrm{~mL}$ Schlenk flask, a solution of 4-hydroxy[2.2]paracyclophane (644.9 $\mathrm{mg}, 2.88 \mathrm{mmol})$ in $50 \mathrm{~mL}$ of anhydrous toluene was treated with 4-(dimethylamino)pyridine (DMAP) (703.7 mg, $5.76 \mathrm{mmol})$ and diethylcarbamoyl chloride $(0.73 \mathrm{~mL}, 5.76 \mathrm{mmol})$. The resulting mixture was stirred and heated at reflux for $7 \mathrm{~h}$, while the progress of the reaction was monitored by TLC (silica gel, dichloromethane). The reaction was cooled to room temperature, hydrolyzed with 50 $\mathrm{mL}$ of deionized water, and extracted $(3 \times 35 \mathrm{~mL})$ with dichloromethane. The combined organic extracts were dried over $\mathrm{Na}_{2} \mathrm{SO}_{4}$. The solvent was removed by rotary evaporation, and the raw product was purified by column chromatography (silica gel, dichloromethane) to afford a colorless crystalline solid (698.9 mg, 75\%). ${ }^{1} \mathrm{H}$ NMR $\left(\mathrm{CDCl}_{3}, 400 \mathrm{MHz}, 25{ }^{\circ} \mathrm{C}\right): \delta 6.85(\mathrm{dd}, \mathrm{J}=$ 7.8, $1.3 \mathrm{~Hz}, 1 \mathrm{H}), 6.41-6.57(\mathrm{~m}, 5 \mathrm{H}), 6.12$ (d, J = 1.3 Hz, $1 \mathrm{H}), 3.66$ (q, br, 2 H), 3.40 (q, br, 2 $\mathrm{H}), 3.25(\mathrm{~m}, 1 \mathrm{H}), 3.05,(\mathrm{~m}, 6 \mathrm{H}), 2.73(\mathrm{~m}, 1 \mathrm{H}), 1.42(\mathrm{t}, \mathrm{br}, 3 \mathrm{H}), 1.22(\mathrm{t}, \mathrm{br}, 3 \mathrm{H}){ }^{13} \mathrm{C}$ NMR $\left(\mathrm{CDCl}_{3}, 100 \mathrm{MHz}, 25^{\circ} \mathrm{C}\right): \delta 153.7,149.5,141.3,139.5,139.3,135.1,133.4,133.0,132.2,131.1$, $129.5,129.4,128.6,42.2,41.9,35.3,34.9,34.6,31.7,14.5,13.5$. 


\section{4-Diethylcarbamoyl-5-iodo[2.2]paracyclophane, ${ }^{10} 11$}

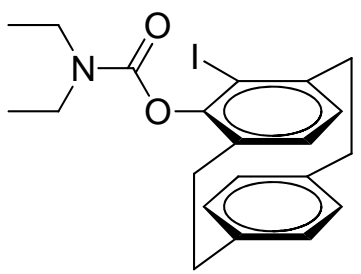

In a $250 \mathrm{~mL}$ Schlenk tube, a solution of O-(4-[2.2]paracyclophanyl) diethylcarbamate (698.9 $\mathrm{mg}$, $2.16 \mathrm{mmol}$ ) in $55 \mathrm{~mL}$ of anhydrous tetrahydrofuran (THF) was treated with tetramethylethyldiamine (TMEDA) $(0.39 \mathrm{~mL}, 2.6 \mathrm{mmol})$ and cooled to $-78{ }^{\circ} \mathrm{C}$. The resulting mixture was treated with sec-butyllithium (1.4 M in cyclohexane, $1.1 \mathrm{~mL}, 2.9 \mathrm{mmol}$, drop wise) and stirred at $-78^{\circ} \mathrm{C}$ for $2 \mathrm{~h}$. The reaction mixture became clear yellow. After $2 \mathrm{~h}$, a solution of diiodoethane $(1.83 \mathrm{~g}, 6.48 \mathrm{mmol})$ in anhydrous THF was added drop wise to the reaction mixture, and the solution was allowed to warm slowly to room temperature overnight. After 15 $\mathrm{h}$, the solution had turned dark purple. The THF was removed in vacuo and the residue was dissolved in $55 \mathrm{~mL}$ of $\mathrm{Et}_{2} \mathrm{O}$ and $55 \mathrm{~mL}$ of aqueous $5 \%$ sodium thiosulfate. The organic layer was washed with an additional $55 \mathrm{~mL}$ of aqueous $5 \%$ sodium thiosulfate. The aqueous phase was extracted with $\mathrm{Et}_{2} \mathrm{O}(3 \times 20 \mathrm{~mL})$. The organic layers were combined, washed with $20 \mathrm{~mL}$ of $1 \mathrm{M}$ $\mathrm{HCl}$, separated, and dried over $\mathrm{Na}_{2} \mathrm{SO}_{4}$. The solvent was evaporated to afford an off-white crystalline solid (949.2 mg, 98\%). ${ }^{1} \mathrm{H} \mathrm{NMR}\left(\mathrm{CDCl}_{3}, 400 \mathrm{MHz}, 25{ }^{\circ} \mathrm{C}\right): \delta 7.14(\mathrm{~d}, \mathrm{~J}=8.0 \mathrm{~Hz}, 1$ H), $6.67(\mathrm{~d}, \mathrm{~J}=7.3 \mathrm{~Hz}, 1 \mathrm{H}), 6.52-6.60(\mathrm{~m}, 3 \mathrm{H}), 6.45(\mathrm{~d}, \mathrm{~J}=7.8 \mathrm{~Hz}, 1 \mathrm{H}), 3.77-3.85(\mathrm{~m}, 1$ $\mathrm{H}), 3.52-3.61(\mathrm{~m}, 1 \mathrm{H}), 3.35-3.47(\mathrm{~m}, 3 \mathrm{H}), 2.97-3.21(\mathrm{~m}, 6 \mathrm{H}), 2.78-2.86(\mathrm{~m}, 1 \mathrm{H}), 1.50(\mathrm{t}$, $\mathrm{J}=7.1 \mathrm{~Hz}, 3 \mathrm{H}), 1.23(\mathrm{t}, \mathrm{J}=7.1 \mathrm{~Hz}, 3 \mathrm{H}) .{ }^{13} \mathrm{C} \mathrm{NMR}\left(\mathrm{CDCl}_{3}, 100 \mathrm{MHz}, 25{ }^{\circ} \mathrm{C}\right): \delta 152.6,149.1$, $145.3,139.1,138.6,134.4,133.3,132.9,132.9$, 130.6, 128.9, 128.6, 103.6, 42.4, 42.1, 39.2, 34.5, $33.0,31.8,14.7,13.4$.

\section{4-Hydroxy-5-iodo[2.2]paracyclophane, ${ }^{10} 12$}

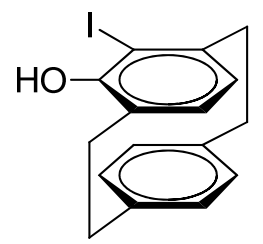

In a $50 \mathrm{~mL}$ round bottom flask, O-[4-(5-iodo-[2.2]paracyclophanyl)] diethylcarbamate (930.8 $\mathrm{mg}, 2.07 \mathrm{mmol})$ and potassium hydroxide $(2.90 \mathrm{~g}, 51.75 \mathrm{mmol})$ were suspended in $15 \mathrm{~mL}$ of ethylene glycol. Hydrazine $(331.7 \mathrm{mg}, 10.35 \mathrm{mmol}$ ) was added and the mixture was heated at reflux for $2 \mathrm{~h}$. During the reflux period, the mixture became homogenous. The solution was cooled to room temperature, transferred to a separatory funnel, acidified to $\mathrm{pH} 1$ with $1 \mathrm{M} \mathrm{HCl}$, and diluted with deionized water. The aqueous phase was extracted with $\mathrm{Et}_{2} \mathrm{O}(4 \times 40 \mathrm{~mL})$. The organic layers were combined, dried over $\mathrm{Na}_{2} \mathrm{SO}_{4}$, and solvent was removed in vacuo to afford an off-white solid (550.2 mg, 78\%). ${ }^{1} \mathrm{H} \mathrm{NMR}\left(\mathrm{CDCl}_{3}, 400 \mathrm{MHz}, 25{ }^{\circ} \mathrm{C}\right): \delta 7.04(\mathrm{dd}, \mathrm{J}=7.8,1.5$ Hz, $1 \mathrm{H}), 6.78(\mathrm{dd}, \mathrm{J}=7.8,1.5 \mathrm{~Hz}, 1 \mathrm{H}), 6.47-6.57$ (m, $3 \mathrm{H}), 6.27$ (d, J = 7.6 Hz, 1H), 5.12 (s, 1 $\mathrm{H}), 3.38-3.44(\mathrm{~m}, 1 \mathrm{H}), 3.25-3.33(\mathrm{~m}, 1 \mathrm{H}), 2.96-3.15(\mathrm{~m}, 5 \mathrm{H}), 2.69-2.76(\mathrm{~m}, 1 \mathrm{H}) .{ }^{13} \mathrm{C}$ NMR $\left(\mathrm{CDCl}_{3}, 100 \mathrm{MHz}, 25^{\circ} \mathrm{C}\right): \delta 152.3,144.5,139.7,137.7,134.9,133.1,133.0,128.1,127.3$, $126.2,125.6,99.5,39.3,34.0,32.9,31.5$. 


\section{4-Methoxy-5-iodo[2.2]paracyclophane, ${ }^{10} 13$}

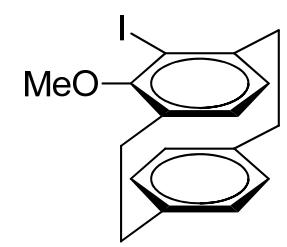

In a $100 \mathrm{~mL}$ glass tube sealed with a Teflon screw cap closure, potassium carbonate $(992.3 \mathrm{mg}$, $7.18 \mathrm{mmol}$ ) and 4-hydroxy-5-iodo[2.2]paracyclophane (548.3 $\mathrm{mg}, 1.56 \mathrm{mmol})$ were heated to 70 ${ }^{\circ} \mathrm{C}$ in $15 \mathrm{~mL}$ of acetone for $30 \mathrm{~min}$. Iodomethane $(553.6 \mathrm{mg}, 3.90 \mathrm{mmol})$ was added to the mixture, the tube was re-sealed, and the stirred solution was heated at $70{ }^{\circ} \mathrm{C}$ for $24 \mathrm{~h}$. The mixture was transferred to a round bottom flask, the solvent was removed by rotary evaporation. The remaining solid was treated with $15 \mathrm{~mL}$ of deionized water and $15 \mathrm{~mL}$ of dichloromethane and transferred to a separatory funnel. The aqueous layer was extracted with dichloromethane (3 $\times 30 \mathrm{~mL}$ ), the organic layers were combined, dried over $\mathrm{Na}_{2} \mathrm{SO}_{4}$, and the solvent was removed in vacuo to yield pale yellow oil. This crude product was purified by column chromatography (60 $\AA$ silica, $10 \%$ EtOAc/hexanes) to afford the pure product as a white solid $(416.7 \mathrm{mg}, 73 \%) .{ }^{1} \mathrm{H}$ $\operatorname{NMR}\left(\mathrm{CDCl}_{3}, 400 \mathrm{MHz}, 25^{\circ} \mathrm{C}\right): \delta 7.09(\mathrm{~d}, \mathrm{~J}=7.9 \mathrm{~Hz}, 1 \mathrm{H}), 6.70(\mathrm{~d}, \mathrm{~J}=7.9 \mathrm{~Hz}, 1 \mathrm{H}), 6.53(\mathrm{~d}, \mathrm{~J}$ $=7.7 \mathrm{~Hz}, 1 \mathrm{H}), 6.52(\mathrm{~s}, 2 \mathrm{H}), 6.35(\mathrm{~d}, \mathrm{~J}=7.7 \mathrm{~Hz}, 1 \mathrm{H}), 3.64(\mathrm{~s}, 3 \mathrm{H}), 3.38-3.43(\mathrm{~m}, 1 \mathrm{H}), 3.26-$ $3.33(\mathrm{~m}, 1 \mathrm{H}), 3.08-3.19(\mathrm{~m}, 2 \mathrm{H}), 2.92-3.03(\mathrm{~m}, 3 \mathrm{H}), 2.74-2.81(\mathrm{~m}, 1 \mathrm{H}) .{ }^{13} \mathrm{C} \mathrm{NMR}$ $\left(\mathrm{CDCl}_{3}, 100 \mathrm{MHz}, 25^{\circ} \mathrm{C}\right): \delta 157.7,145.6,139.4,138.4,135.2,132.8,132.7,131.8,129.4,128.9$, 128.7, 103.5, 60.9, 39.2, 34.5, 33.0, 31.2. 

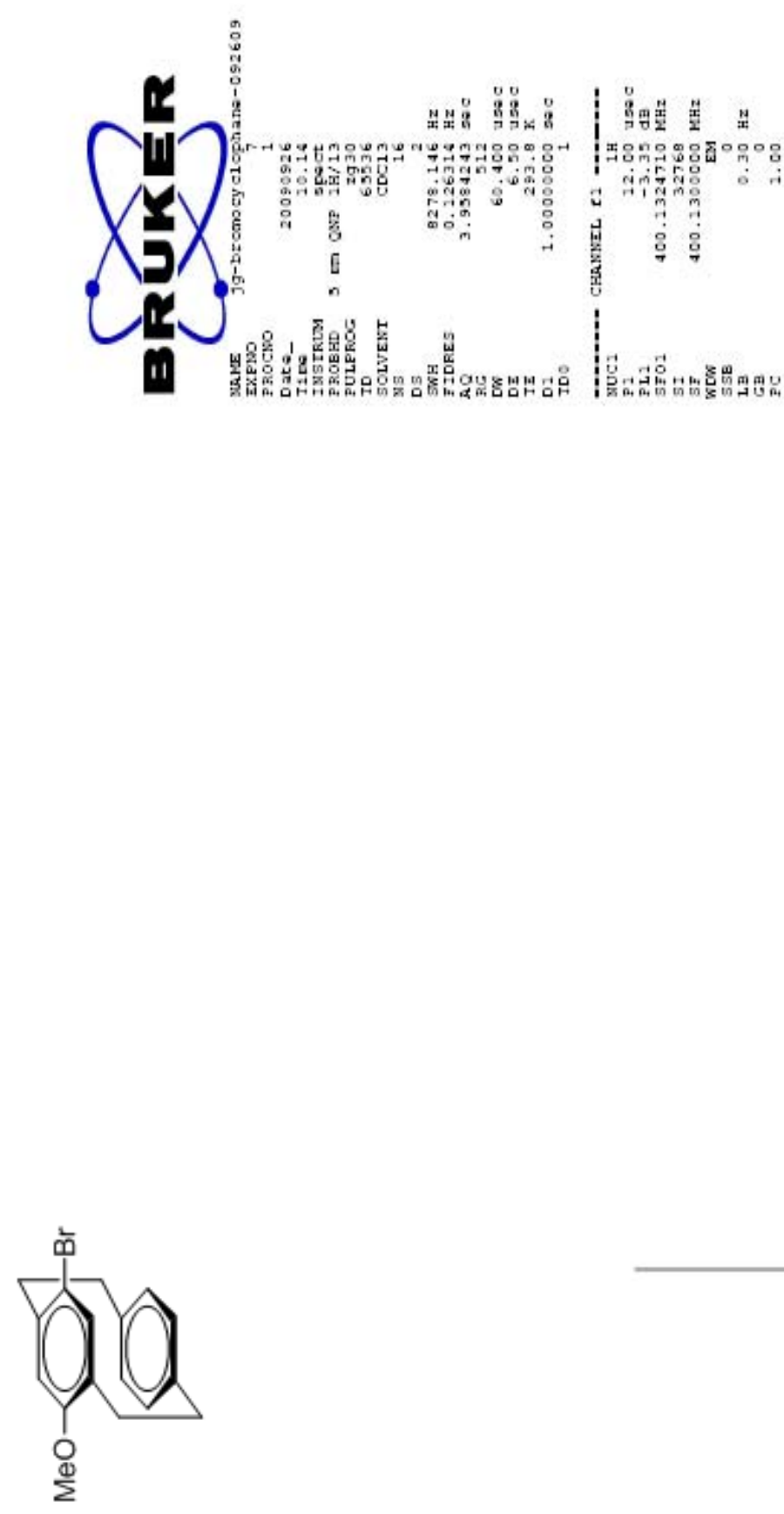

$\omega$

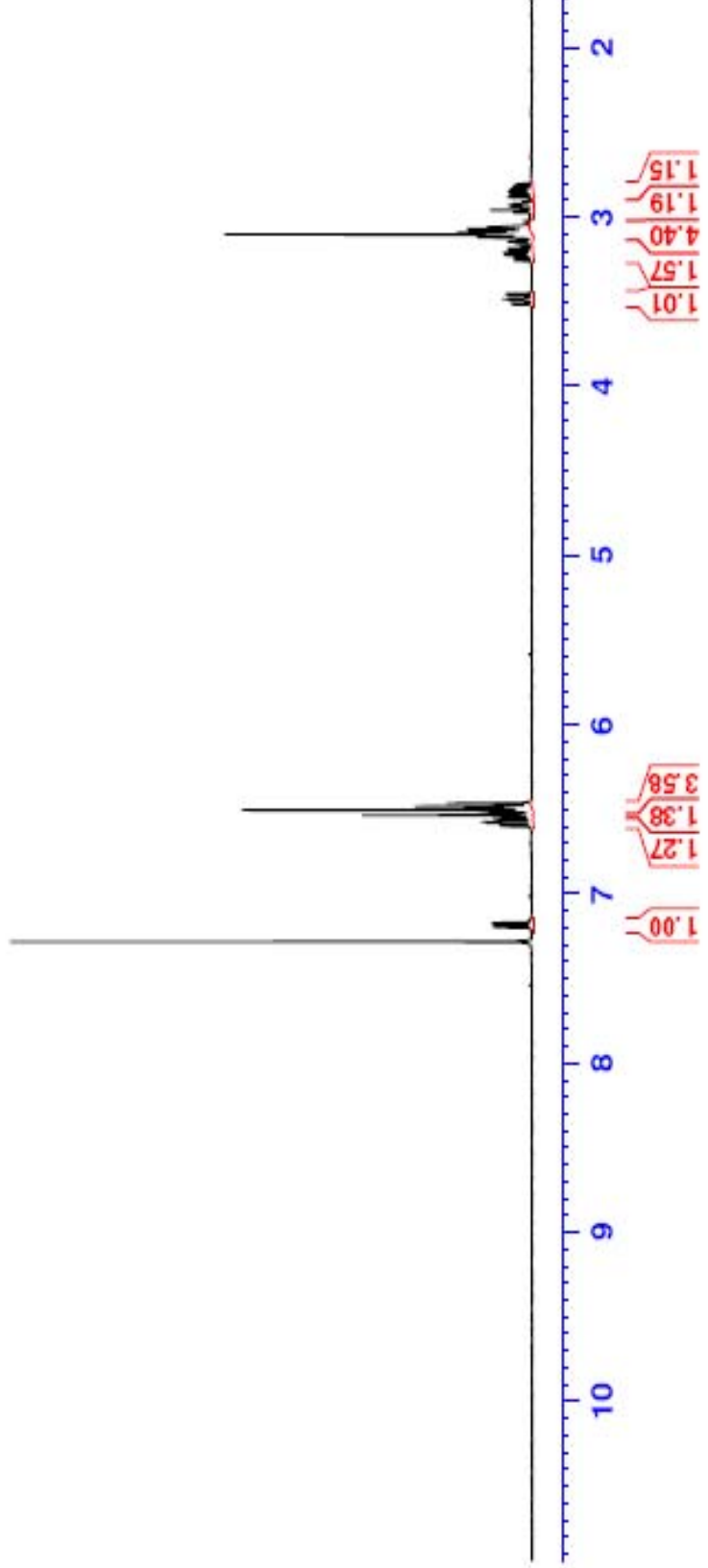

Figure S1. ${ }^{1} \mathrm{H}$ NMR spectrum of 4-bromo[2.2]paracyclophane in $\mathrm{CDCl}_{3}$. 

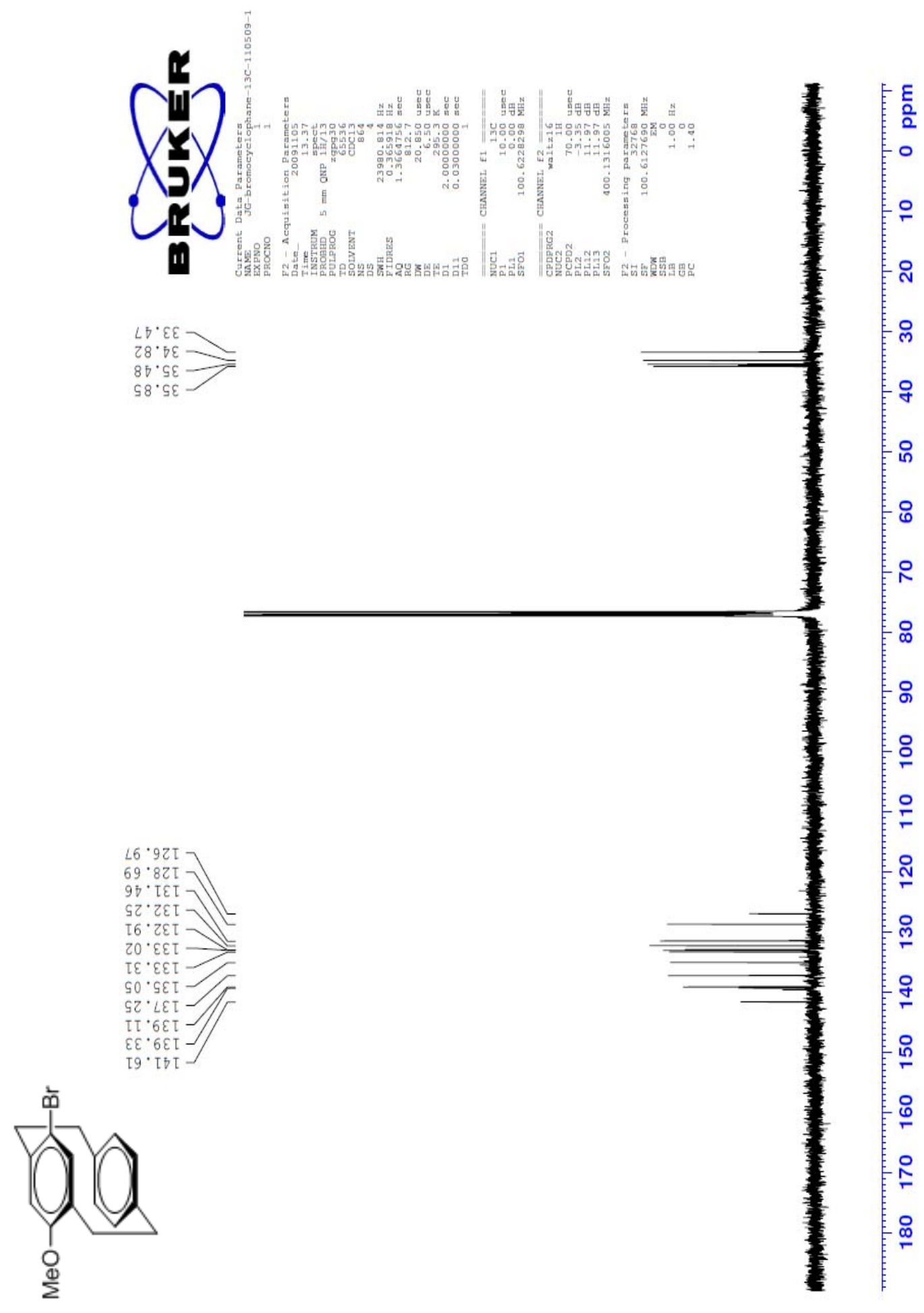

$\omega$

Figure S2. ${ }^{13} \mathrm{C}$ NMR spectrum of 4-bromo[2.2] paracyclophane in $\mathrm{CDCl}_{3}$. 

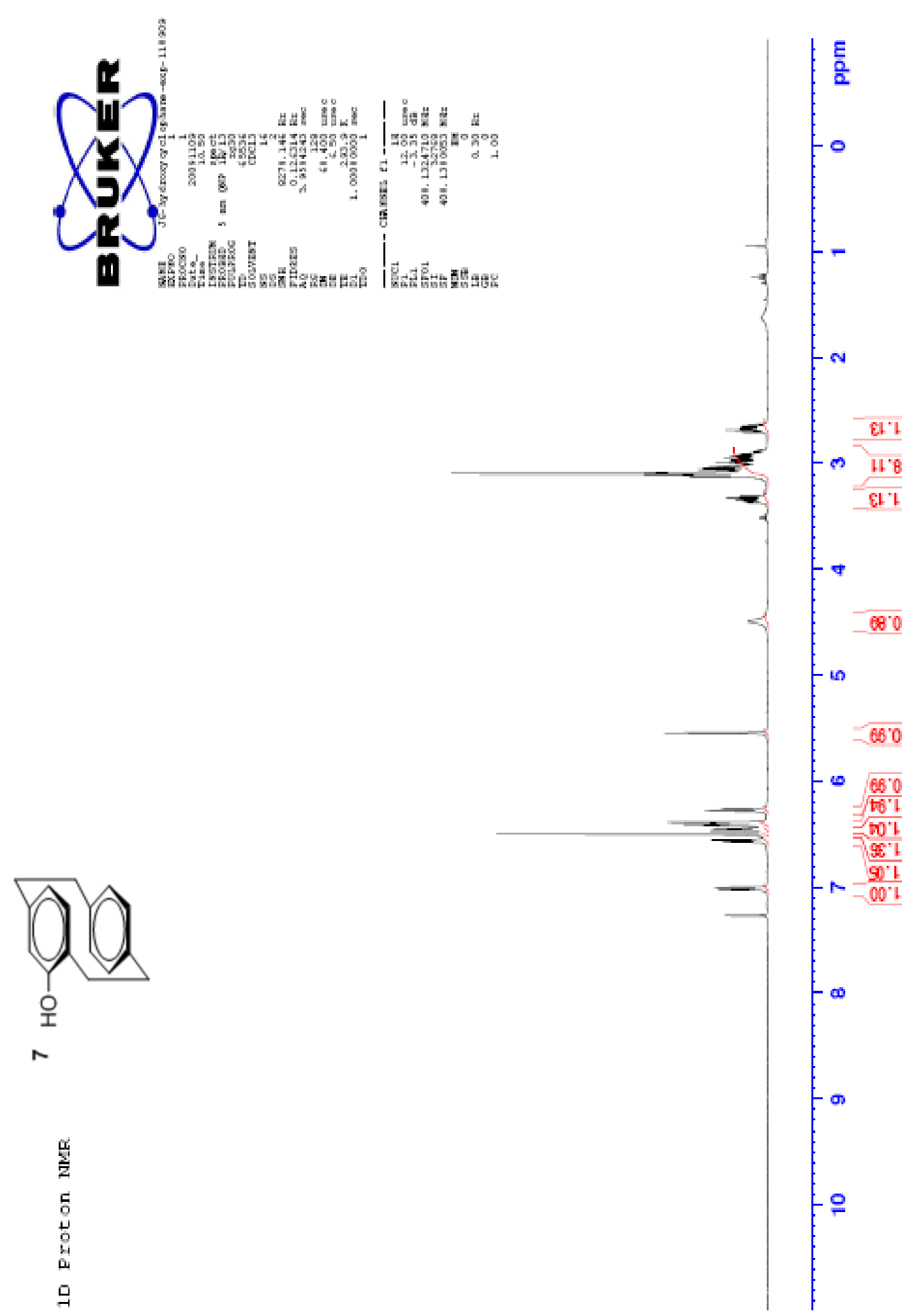

Figure S3. ${ }^{1} \mathrm{~N}$ NMR spectrum of 4-hydroxy[2.2]paracyclophane in $\mathrm{CDCl}_{3}$. 

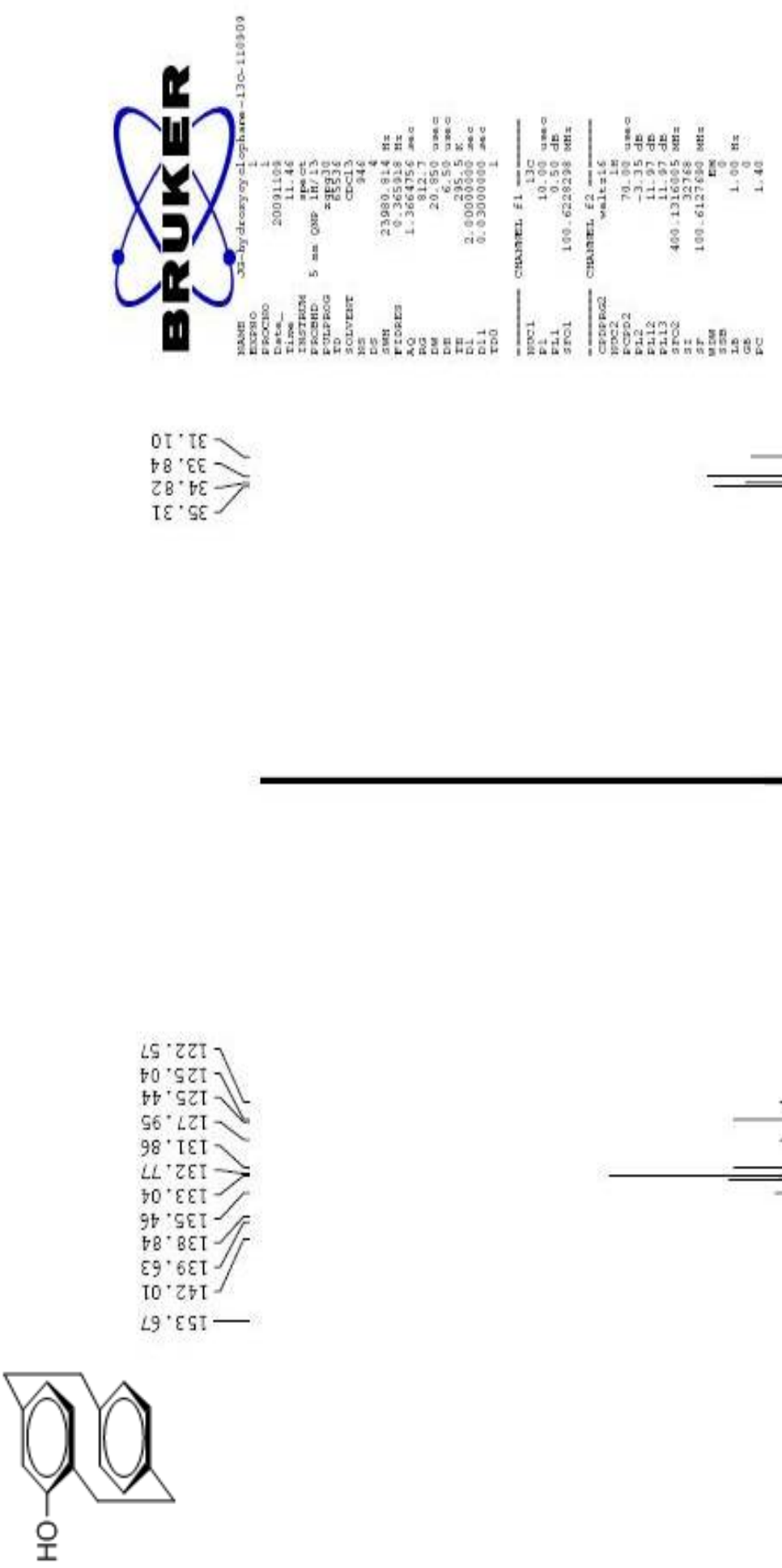

N

Figure S4. ${ }^{13} \mathrm{C}$ NMR spectrum of 4-hydroxy[2.2]paracyclophane in $\mathrm{CDCl}_{3}$. 

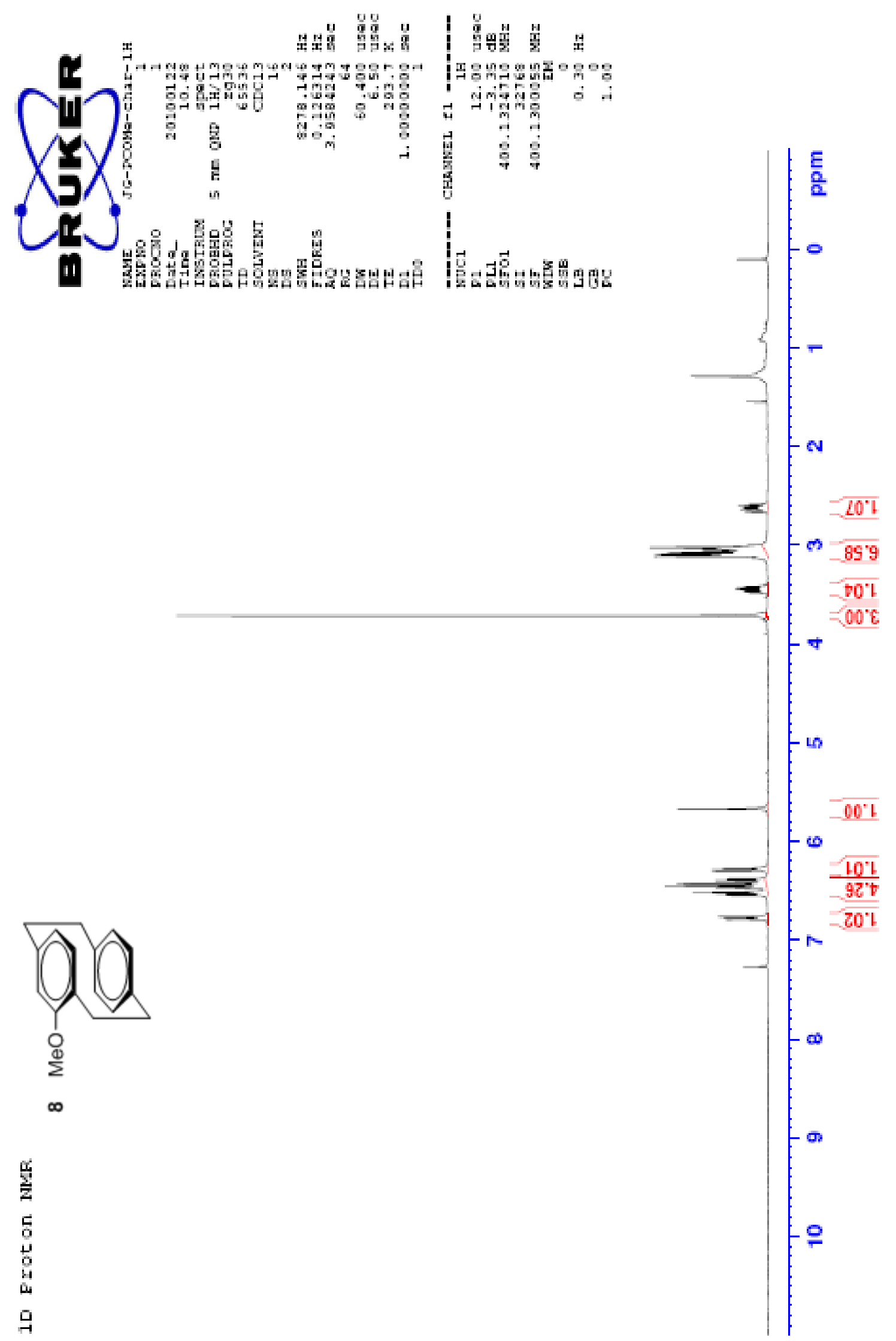

Figure S5. ${ }^{1} \mathrm{H}$ NMR spectrum of 4-methoxy[2.2]paracyclophane in $\mathrm{CDCl}_{3}$. 

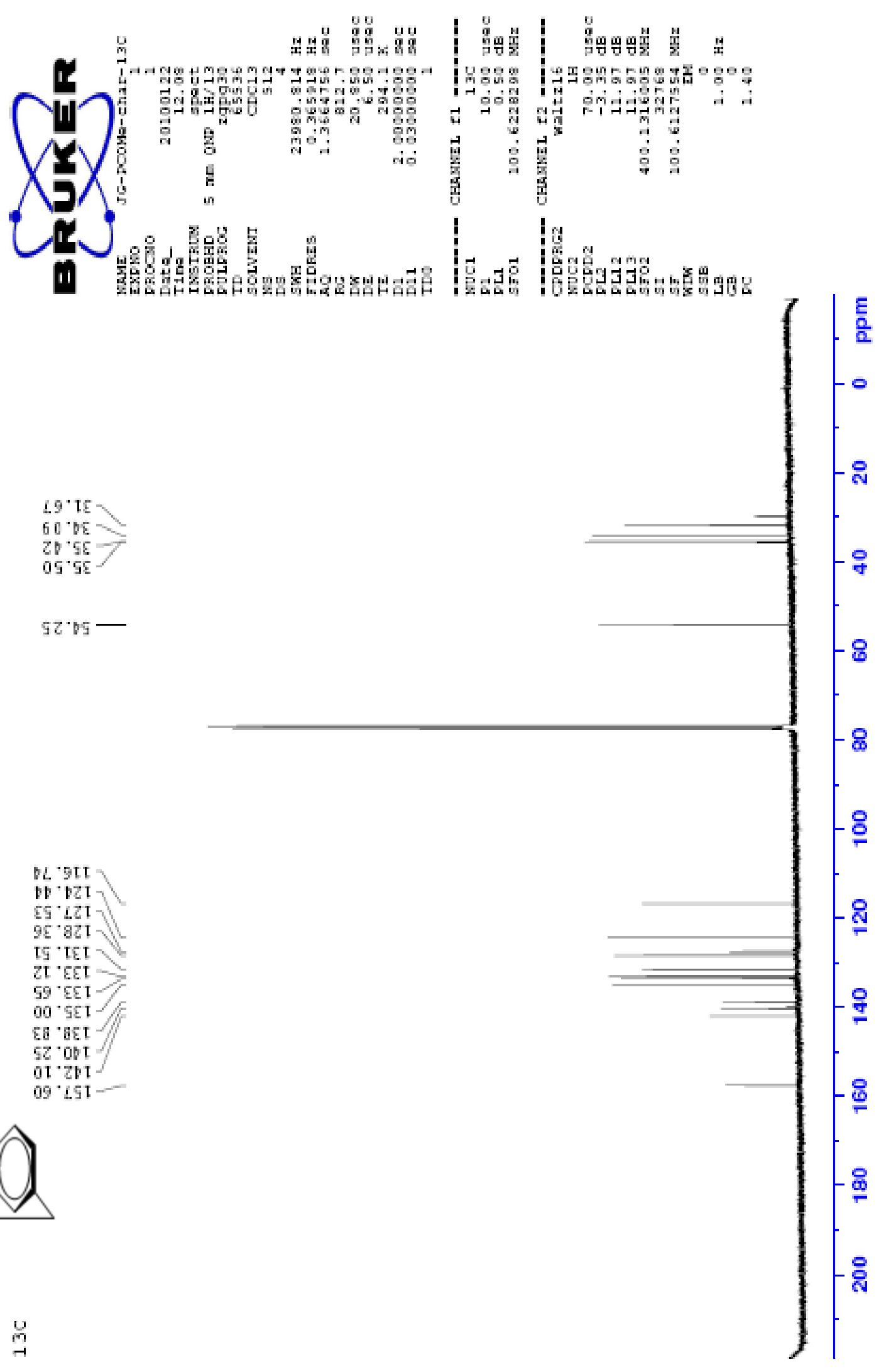

Figure S6. ${ }^{13} \mathrm{C}$ NMR spectrum of 4-methoxy[2.2]paracyclophane in $\mathrm{CDCl}_{3}$. 

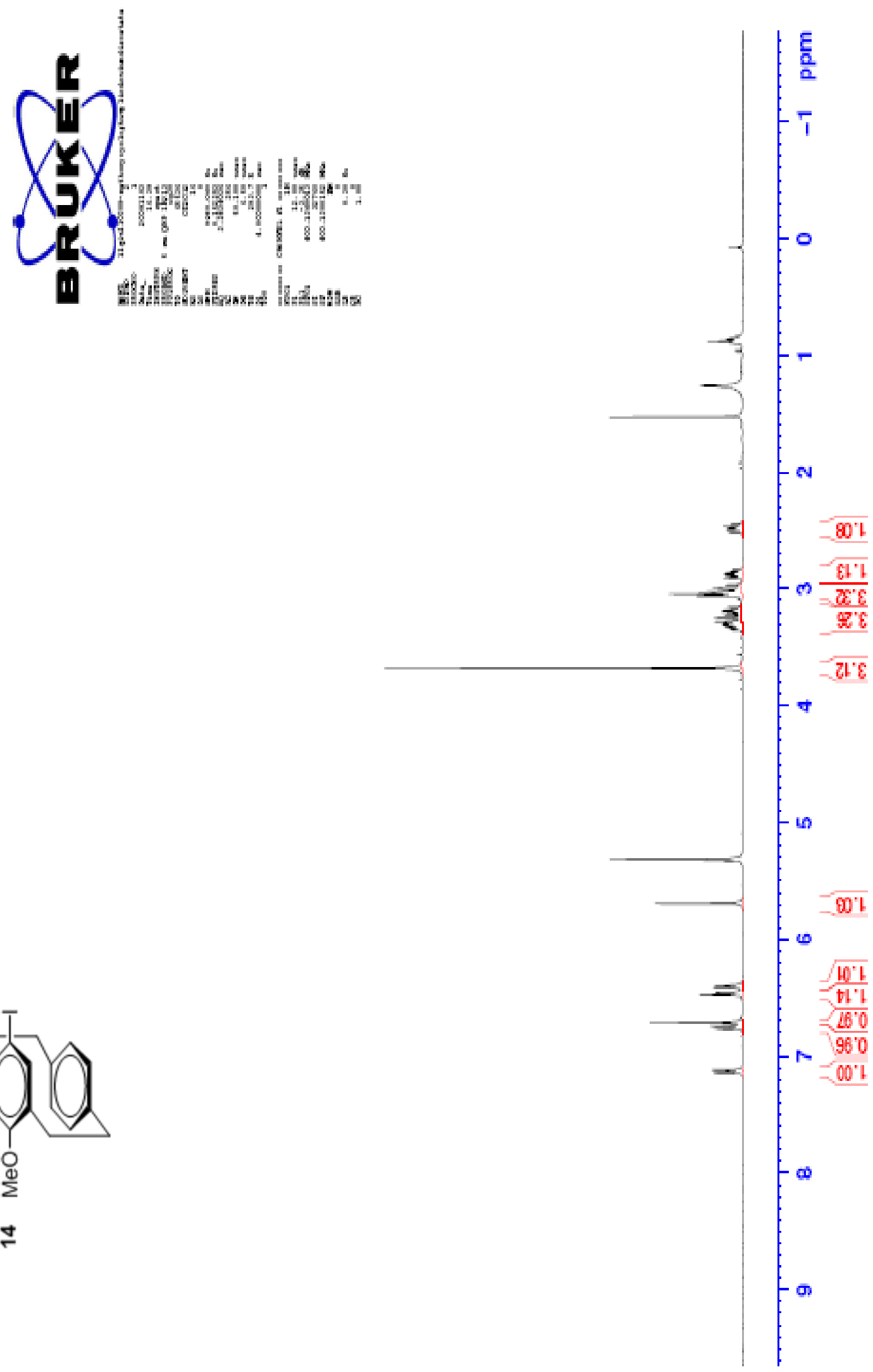

Figure S7. ${ }^{1} \mathrm{H}$ NMR spectrum of 4-methoxy-7-iodo[2.2]paracyclophane in $\mathrm{CD}_{2} \mathrm{Cl}_{2}$. 

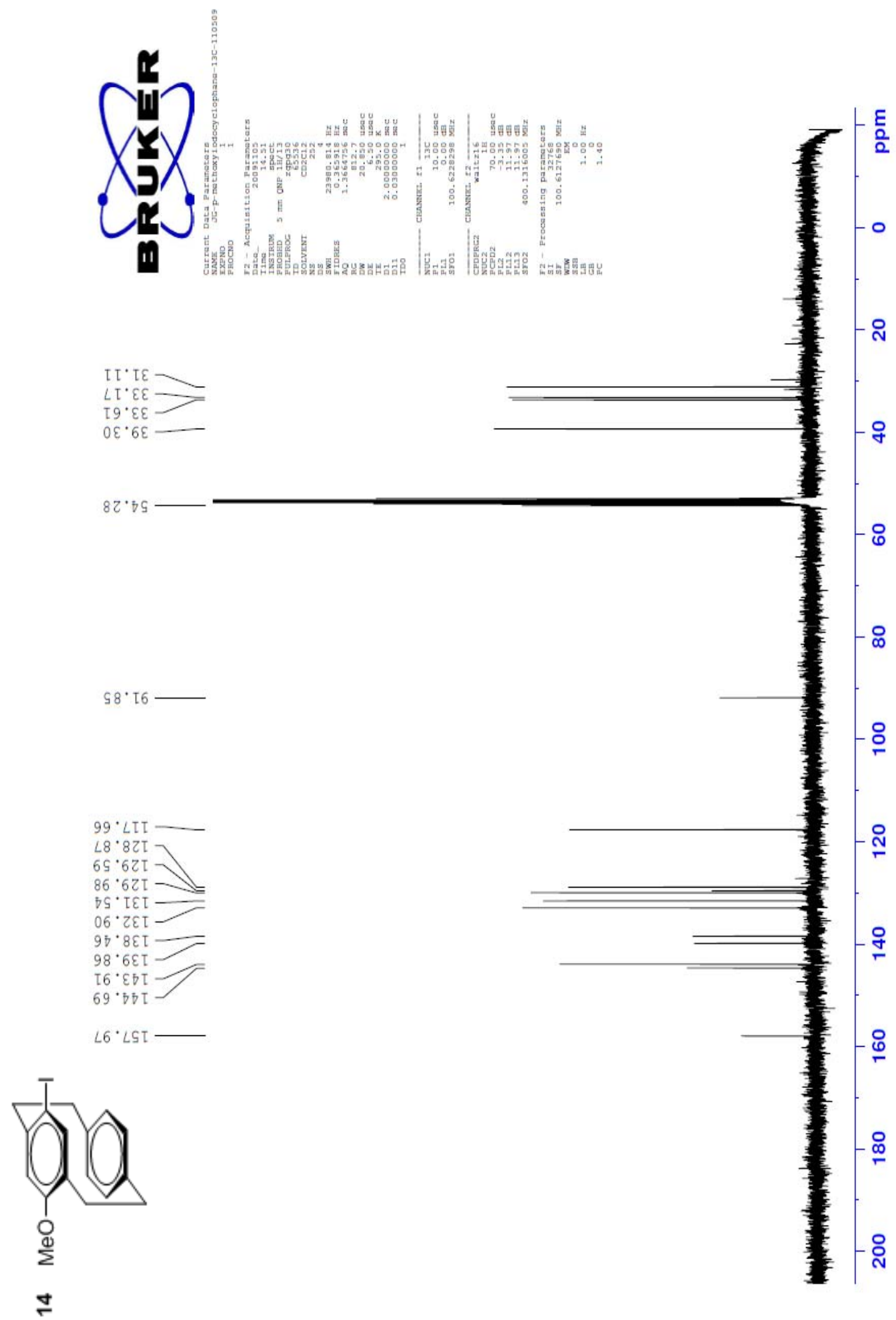

Figure S8. ${ }^{13} \mathrm{C}$ NMR spectrum of 4-methoxy-7-iodo[2.2]paracyclophane in $\mathrm{CD}_{2} \mathrm{Cl}_{2}$. 

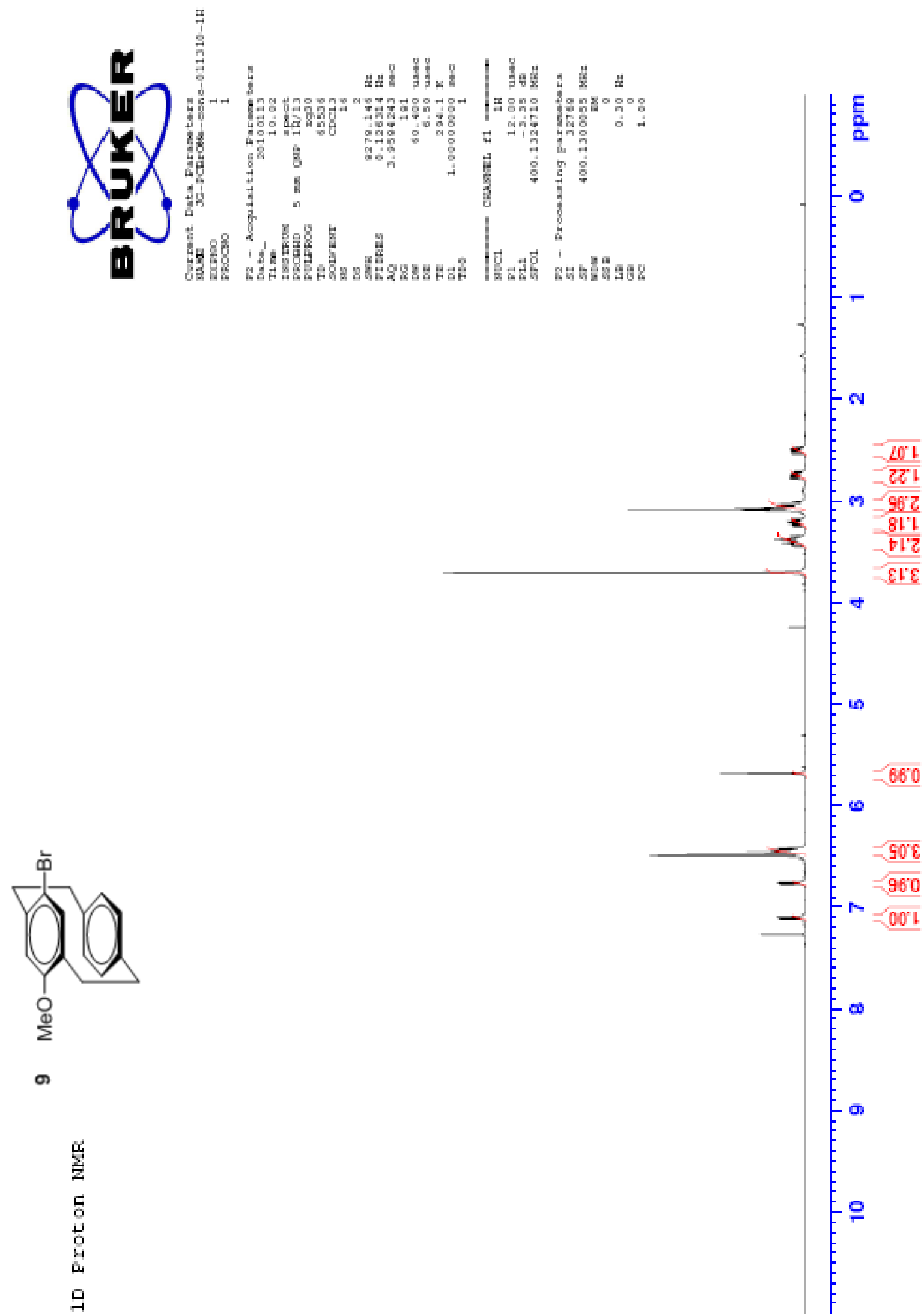

Figure S9. ${ }^{1} \mathrm{H}$ NMR spectrum of 4-methoxy-7-bromo[2.2]paracyclophane in $\mathrm{CDCl}_{3}$. 

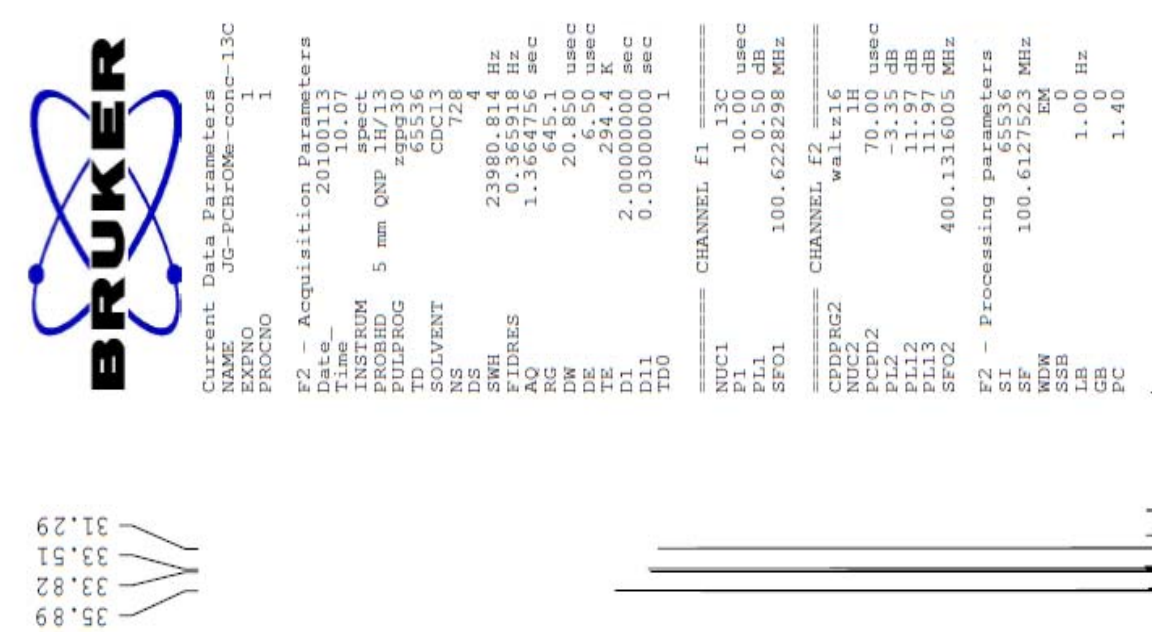

$69^{\circ} 79$

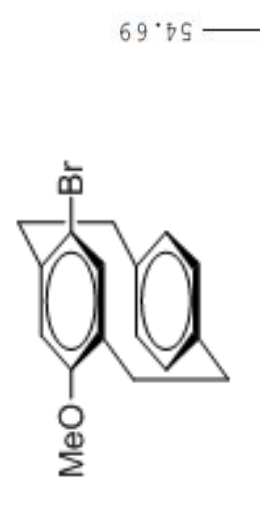

a
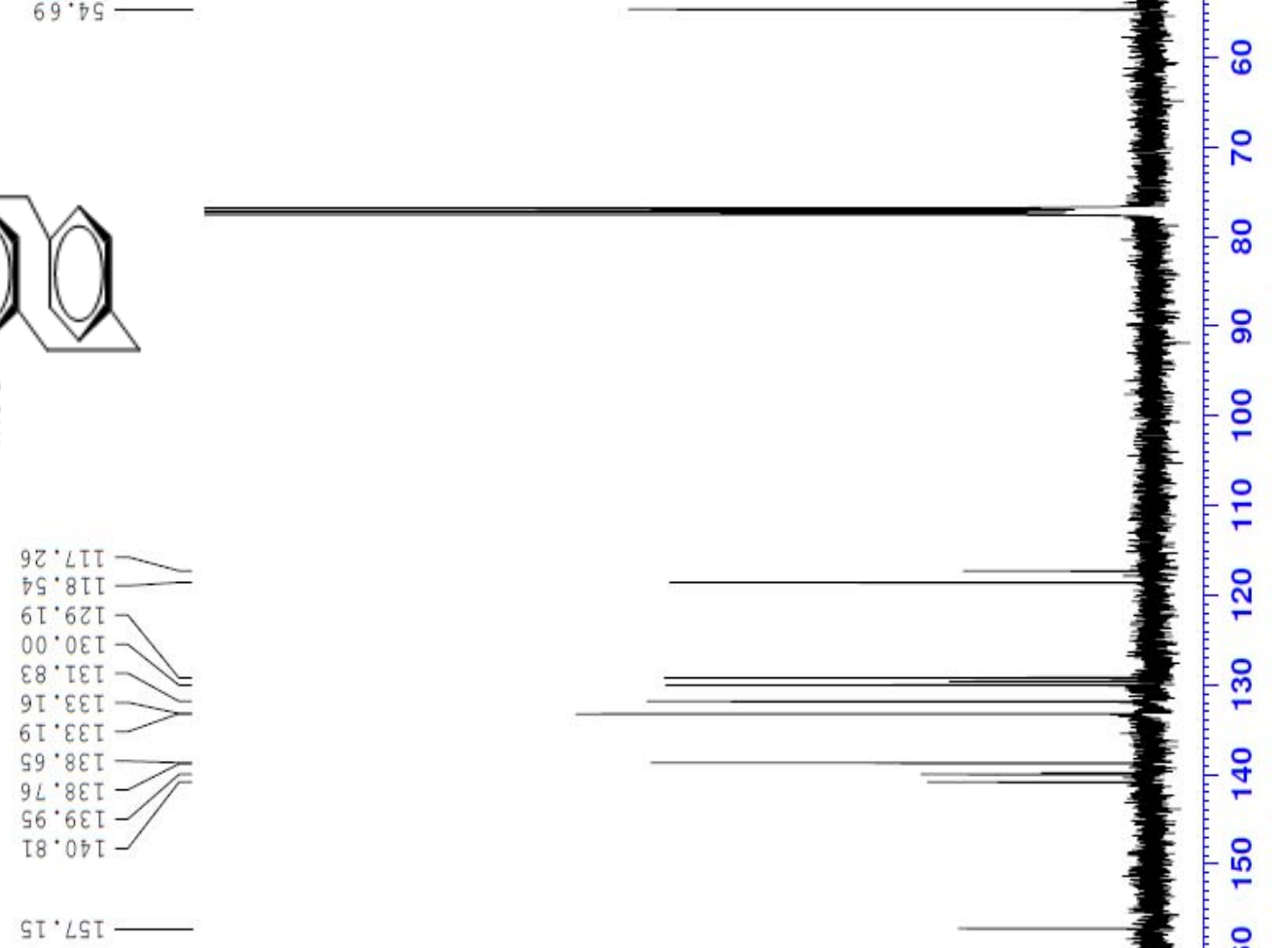


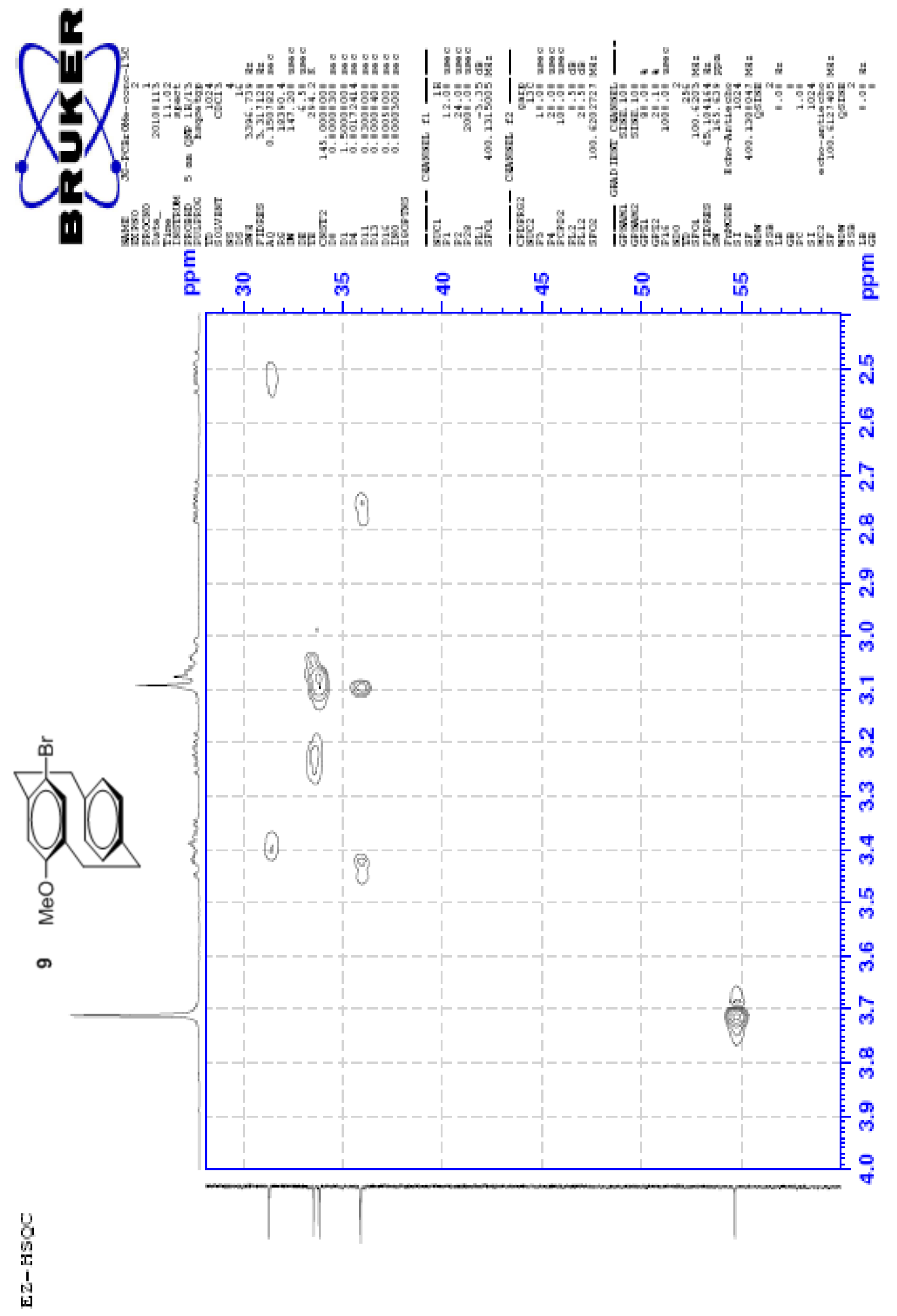

Figure S11. HSQC NMR spectrum (detail) of 4-methoxy-7-bromo[2.2]paracyclophane in $\mathrm{CDCl}_{3}$. 


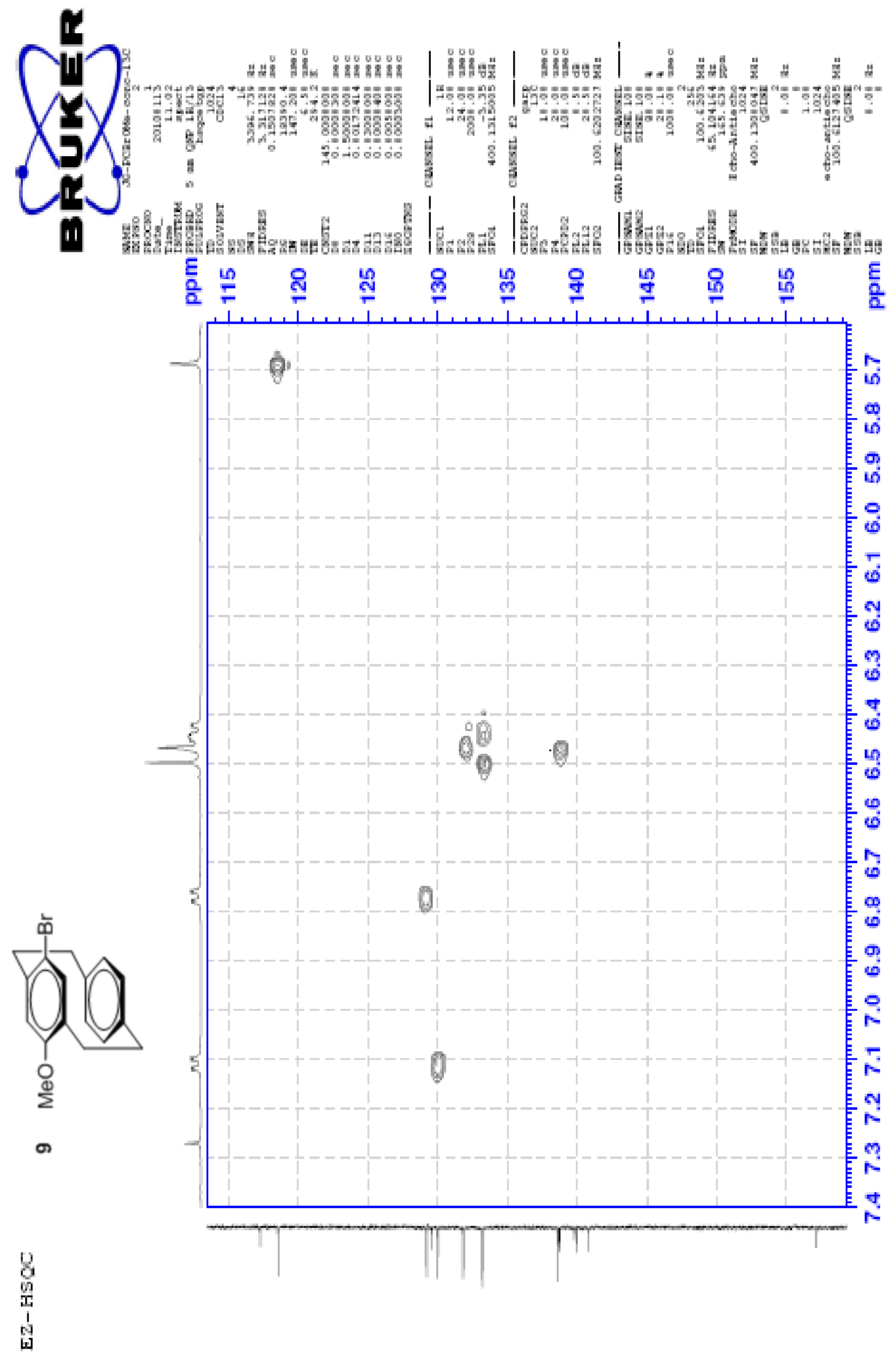

Figure S12. HSQC NMR spectrum (detail) of 4-methoxy-7-bromo[2.2]paracyclophane in $\mathrm{CDCl}_{3}$. 


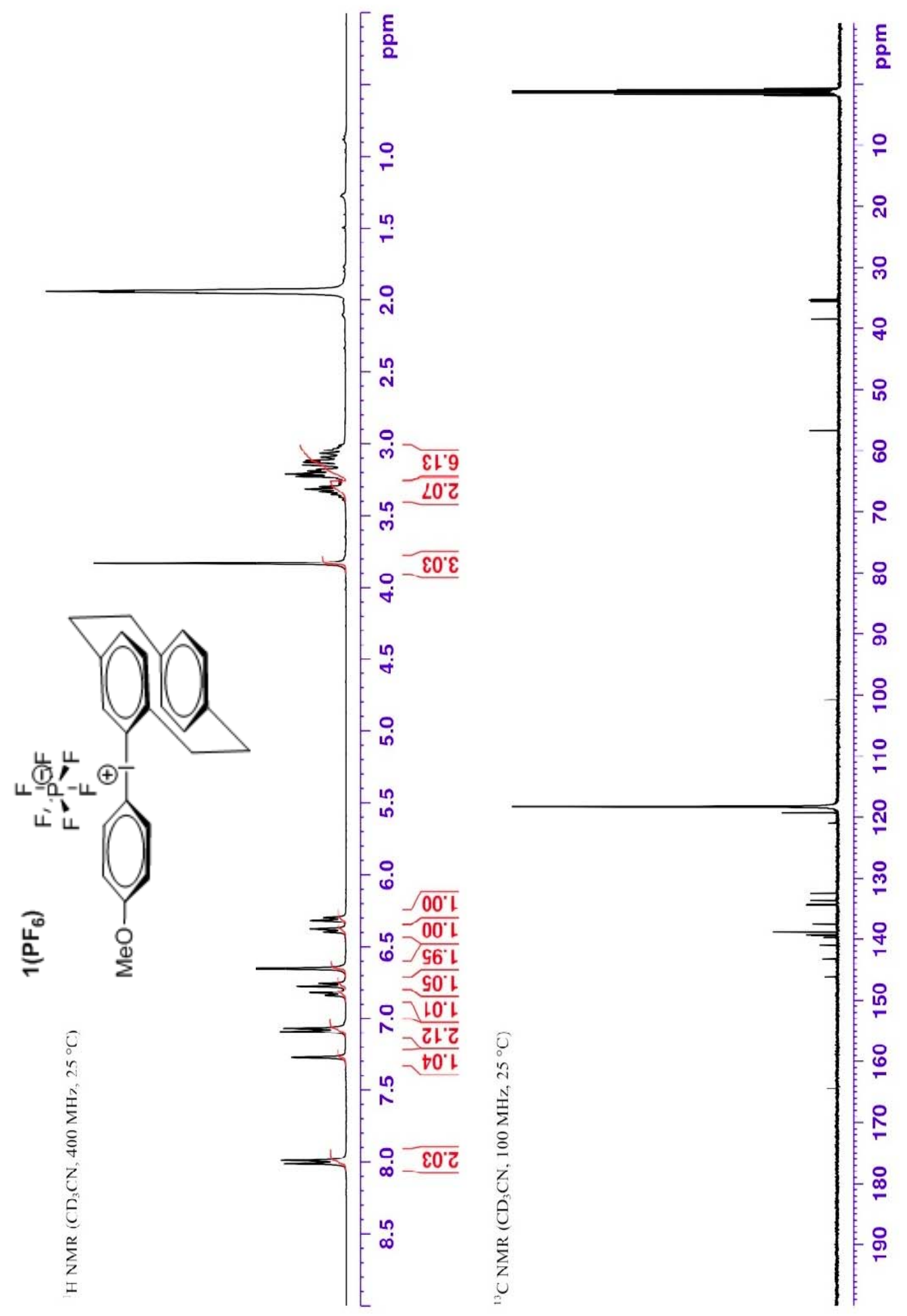

Figure S13. ${ }^{1} \mathrm{H}$ and ${ }^{13} \mathrm{C}$ NMR spectra of $\mathbf{1}\left(\mathbf{P F}_{\mathbf{6}}\right)$ in $\mathrm{CD}_{3} \mathrm{CN}$. 


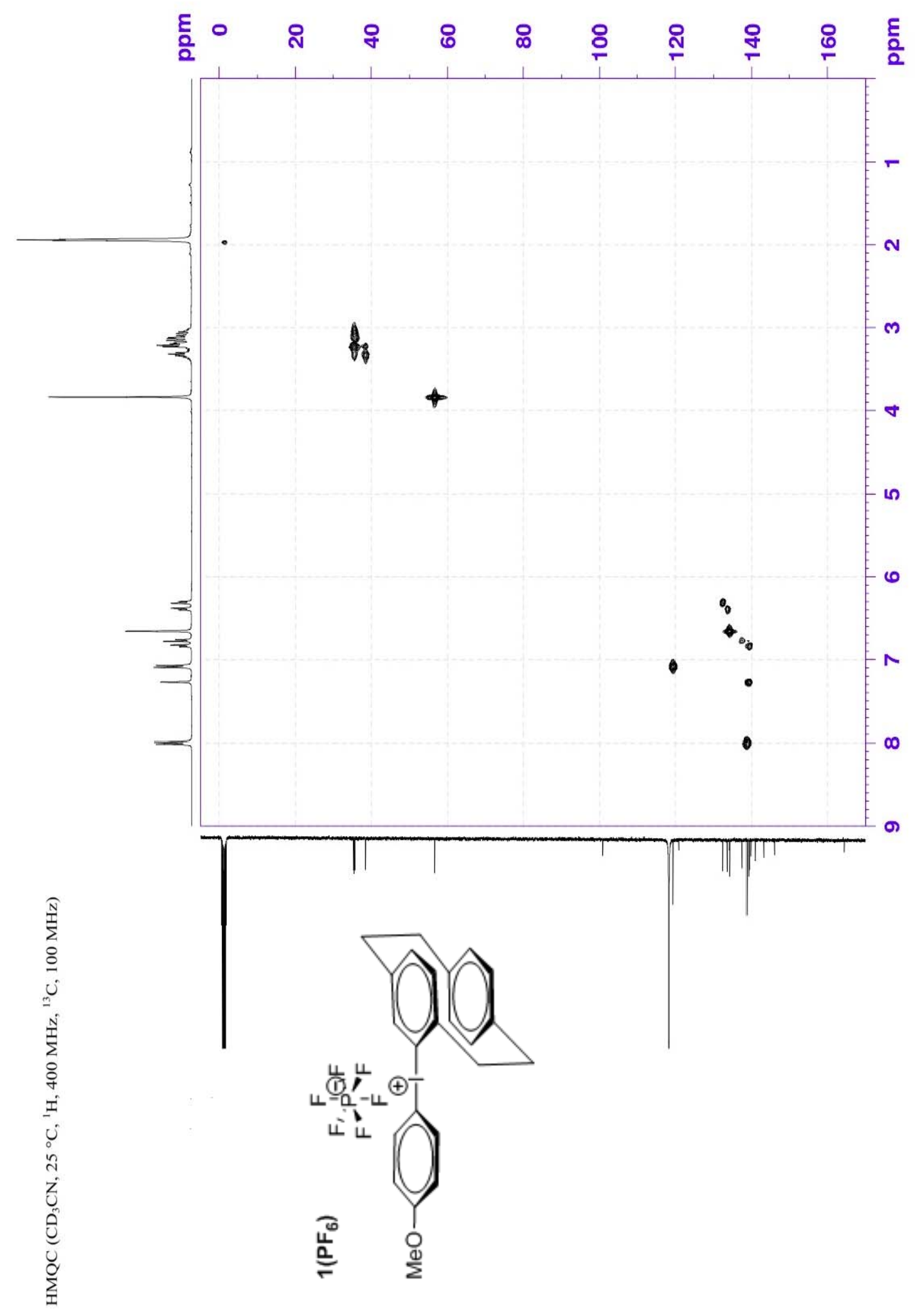

Figure S14. HSQC NMR spectrum of $\mathbf{1}\left(\mathbf{P F}_{\mathbf{6}}\right)$ in $\mathrm{CD}_{3} \mathrm{CN}$. 

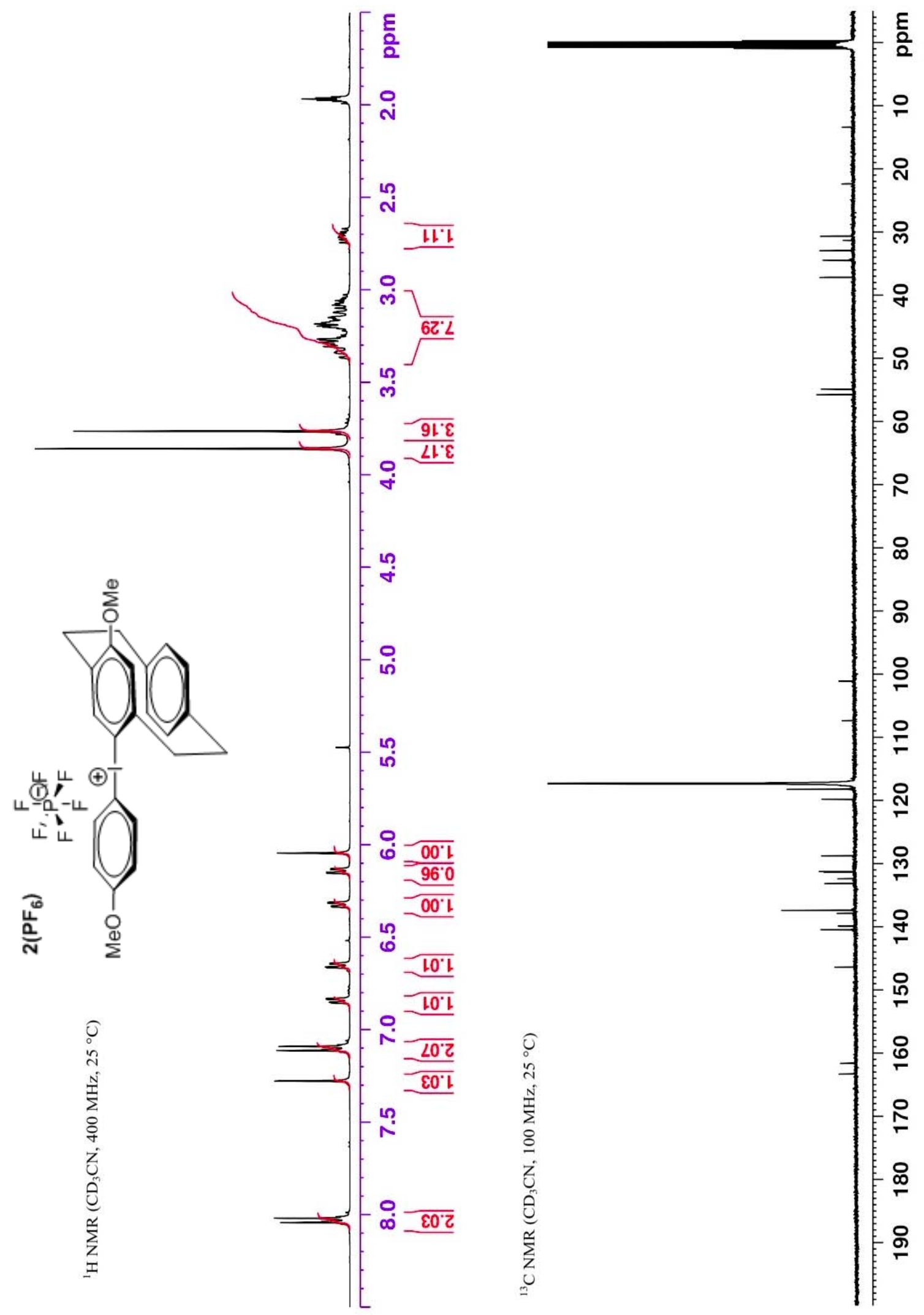

Figure $\mathbf{S 1 5} .{ }^{1} \mathrm{H}$ and ${ }^{13} \mathrm{C}$ NMR spectra of $\mathbf{2}\left(\mathbf{P F}_{\mathbf{6}}\right)$ in $\mathrm{CD}_{3} \mathrm{CN}$. 


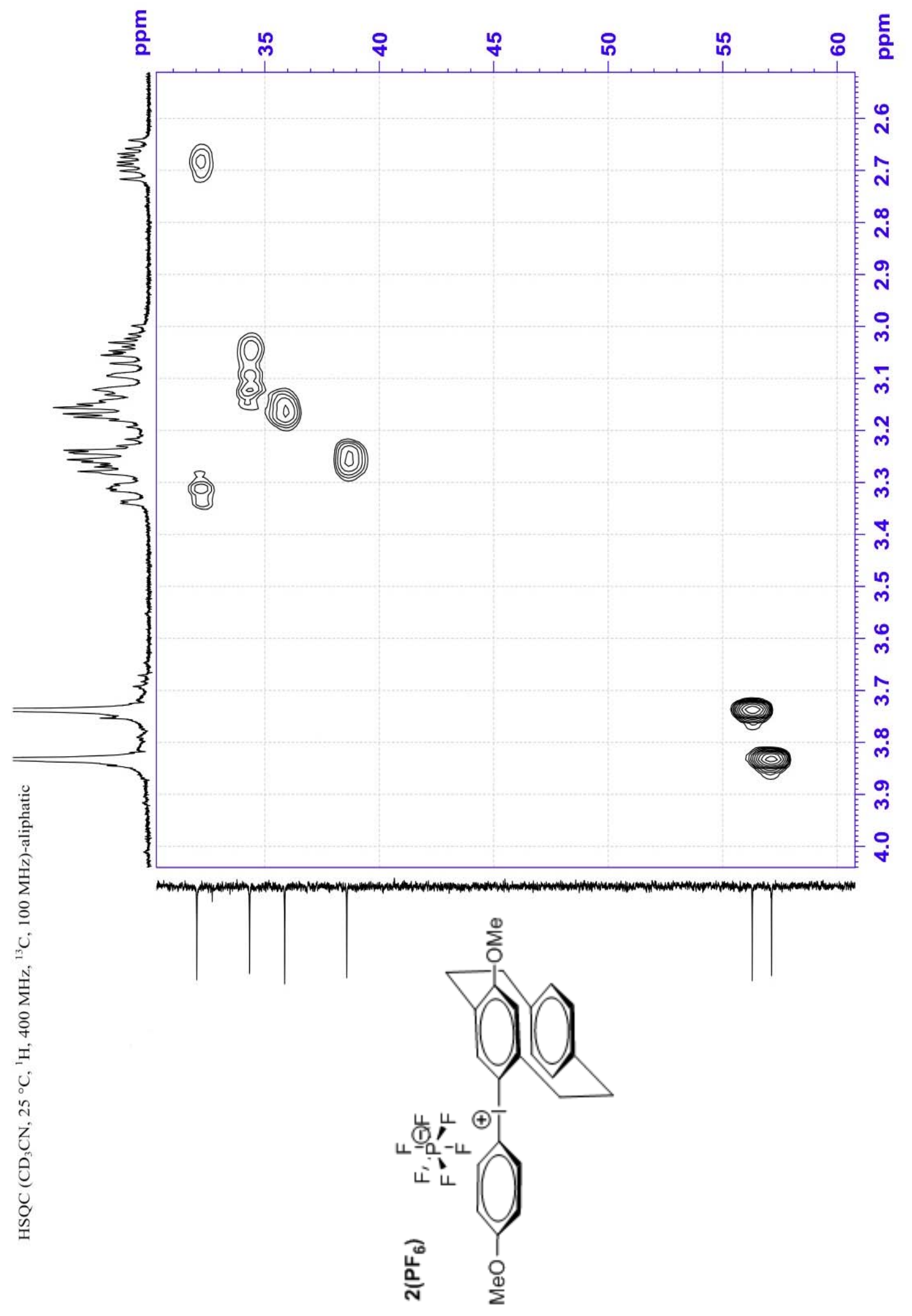

Figure S16. HSQC NMR spectrum (detail) of $\mathbf{2}\left(\mathbf{P F}_{\mathbf{6}}\right)$ in $\mathrm{CD}_{3} \mathrm{CN}$. 


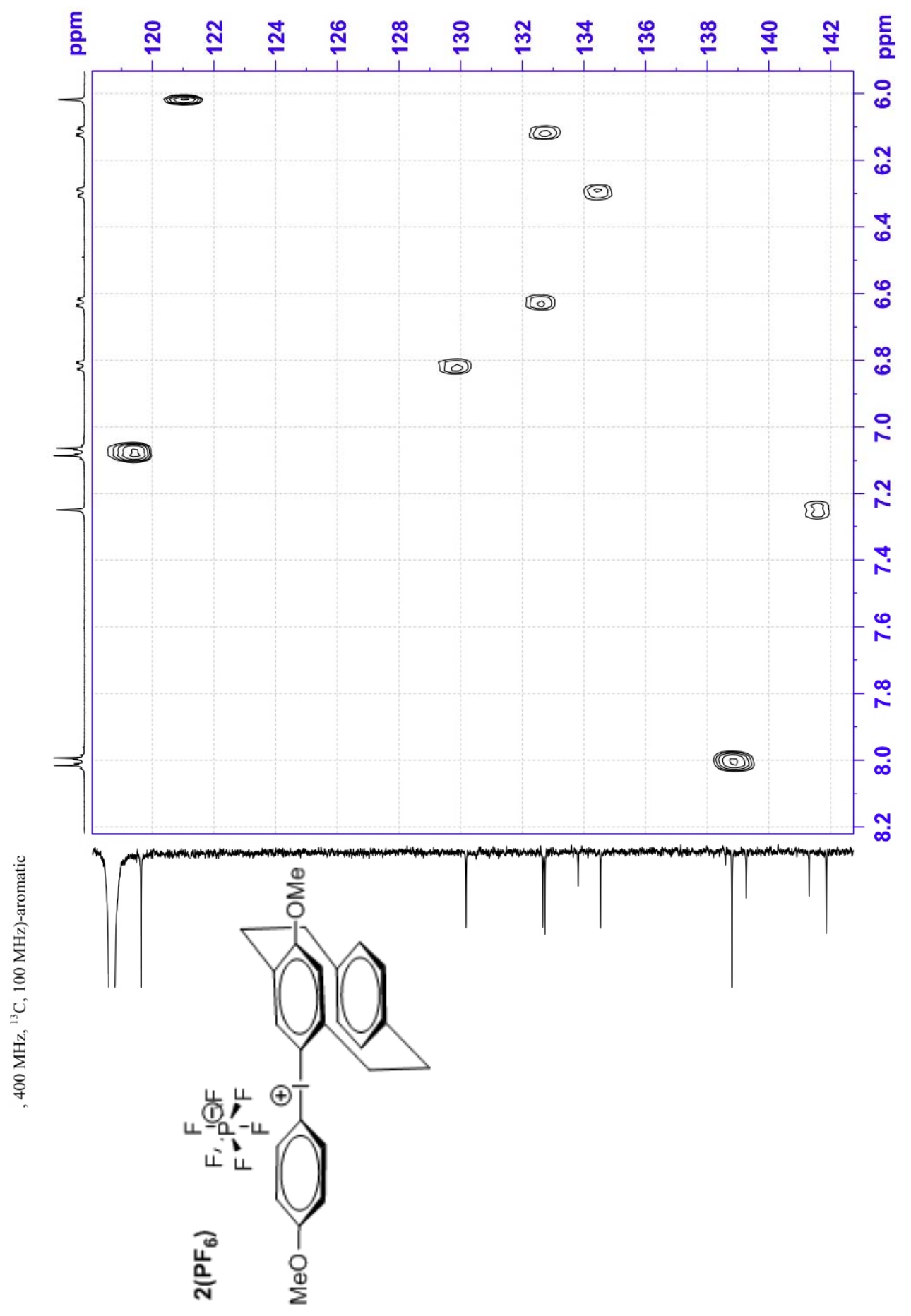

Figure S17. HSQC NMR spectrum (detail) of $\mathbf{2}\left(\mathbf{P F}_{\mathbf{6}}\right)$ in $\mathrm{CD}_{3} \mathrm{CN}$. 


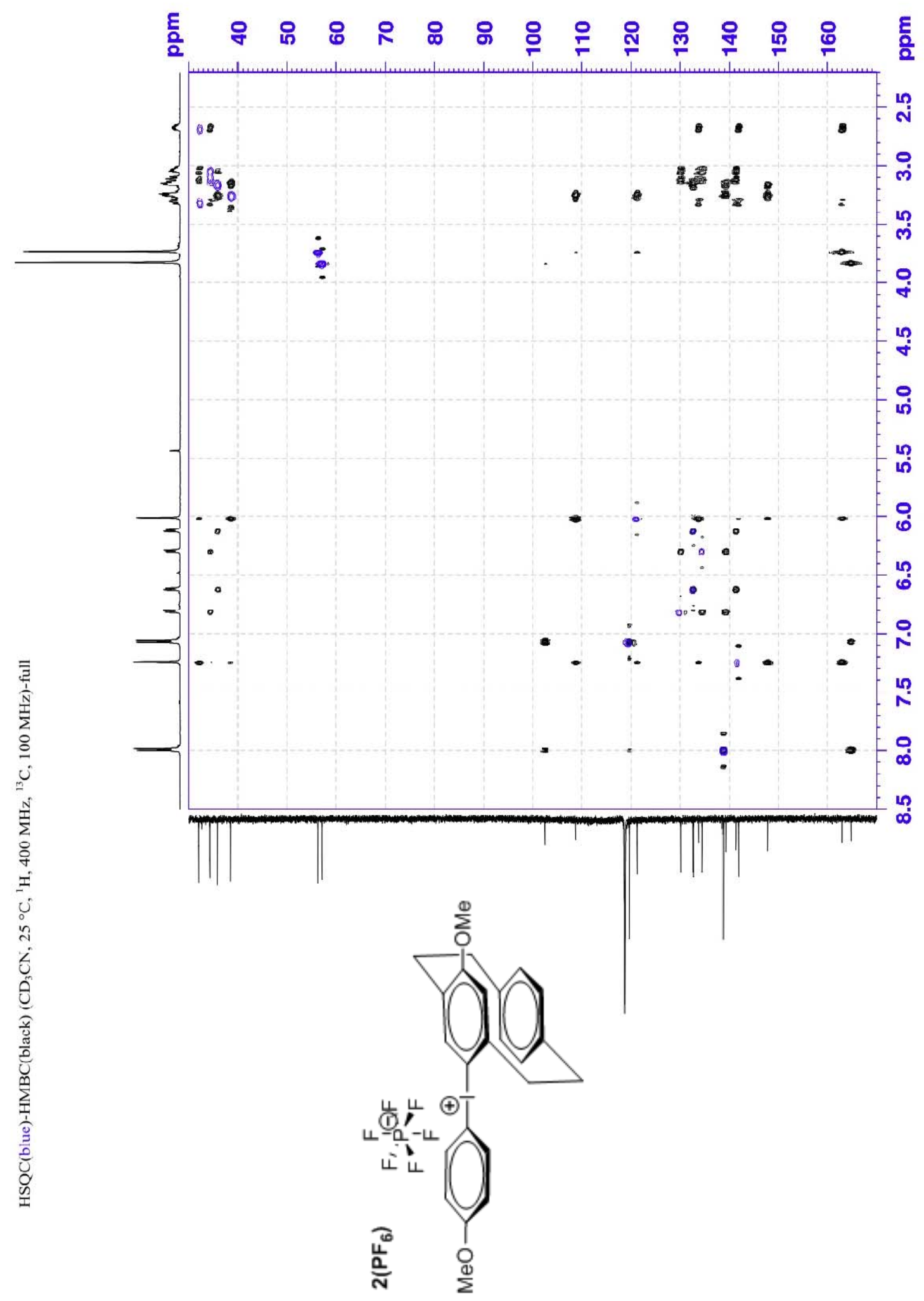

Figure S18. HSQC-HMBC NMR spectrum of $\mathbf{2}\left(\mathbf{P F}_{\mathbf{6}}\right)$ in $\mathrm{CD}_{3} \mathrm{CN}$. 


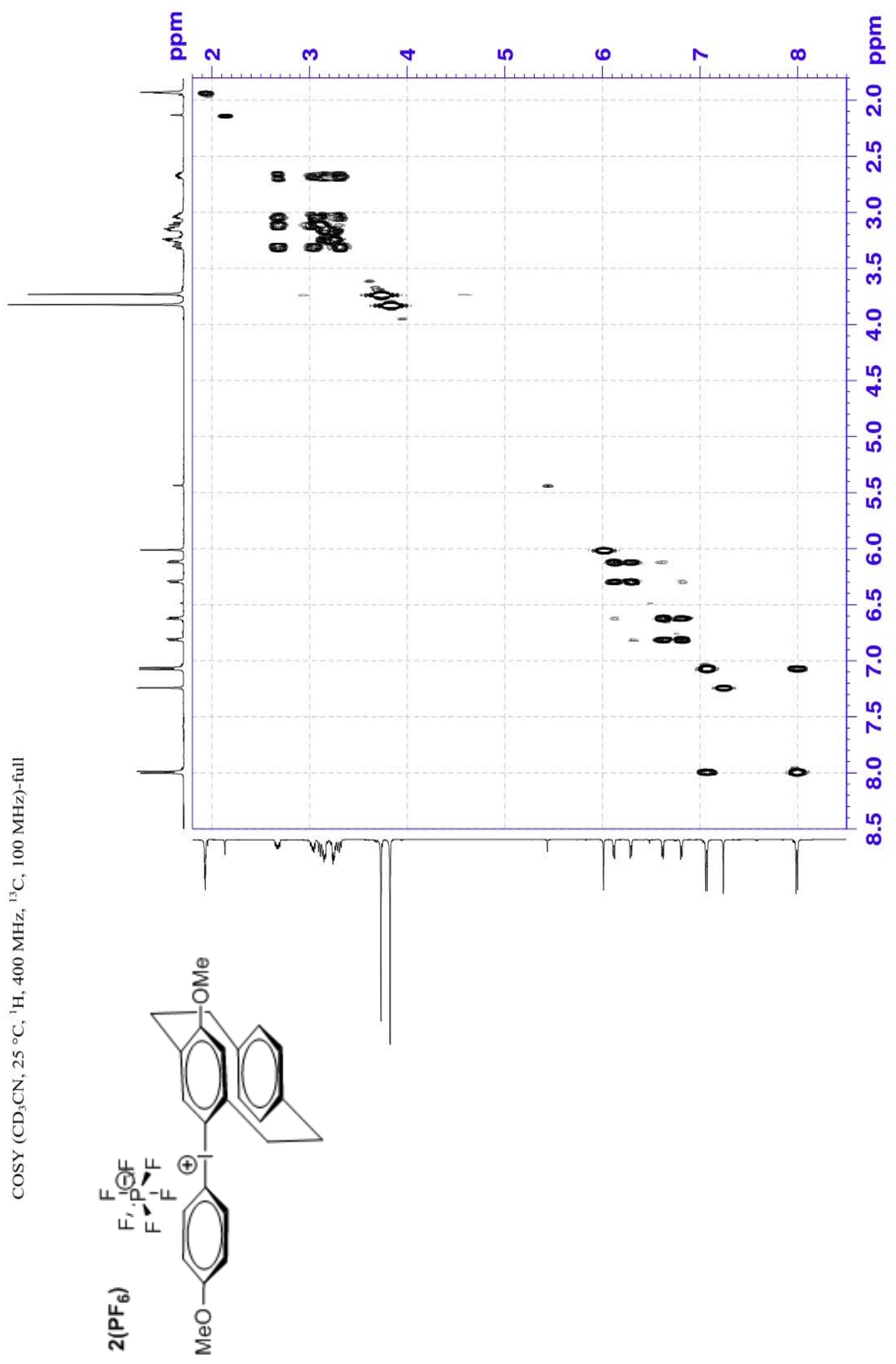

Figure S19. ${ }^{1} \mathrm{H}-{ }^{1} \mathrm{H}$ COSY NMR spectrum of $\mathbf{2}\left(\mathbf{P F}_{\mathbf{6}}\right)$ in $\mathrm{CD}_{3} \mathrm{CN}$. 


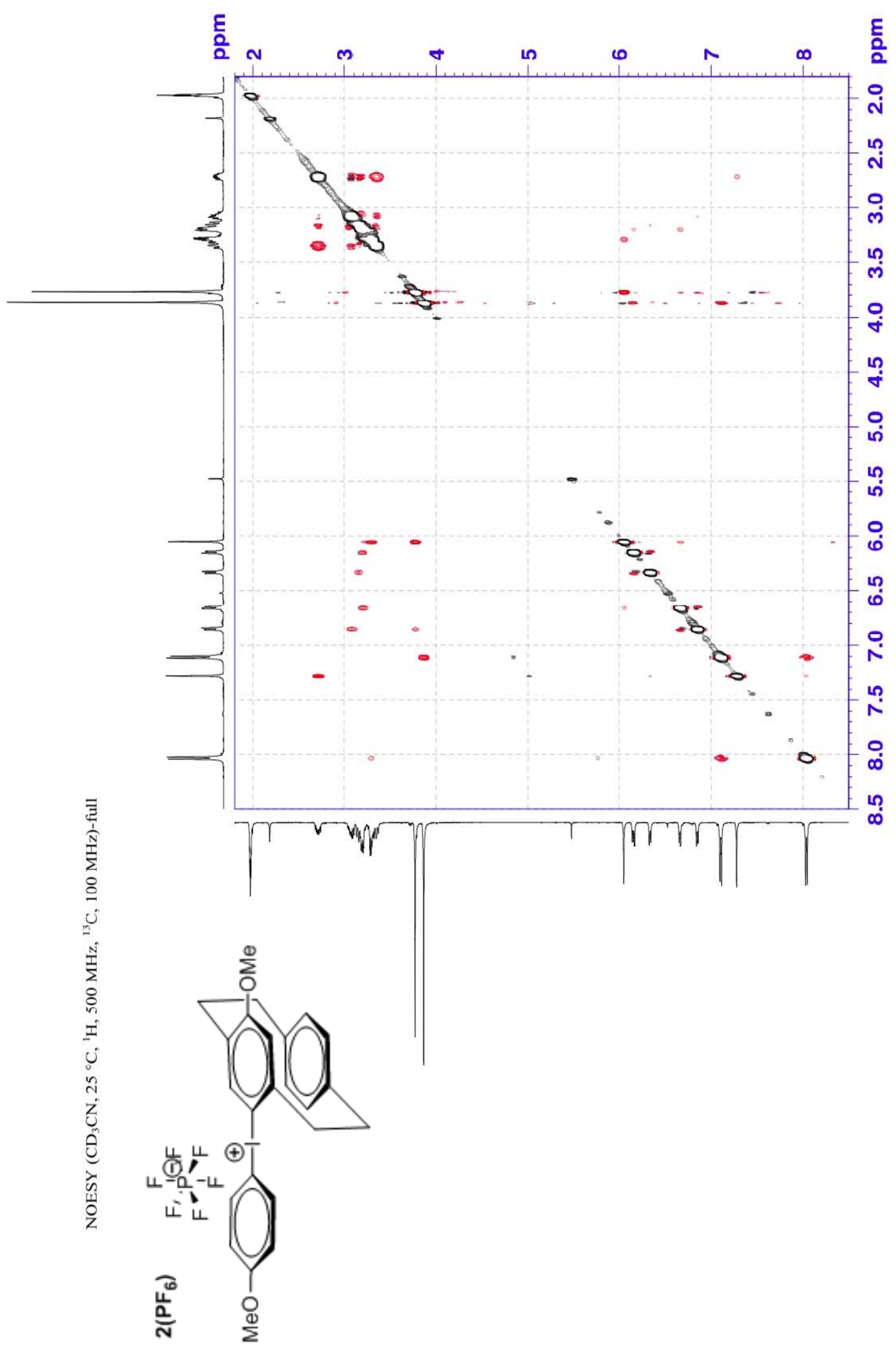

Figure S20. ${ }^{1} \mathrm{H}-{ }^{1} \mathrm{H}$ NOESY NMR spectrum of $\mathbf{2}\left(\mathbf{P F}_{\mathbf{6}}\right)$ in $\mathrm{CD}_{3} \mathrm{CN}$. 


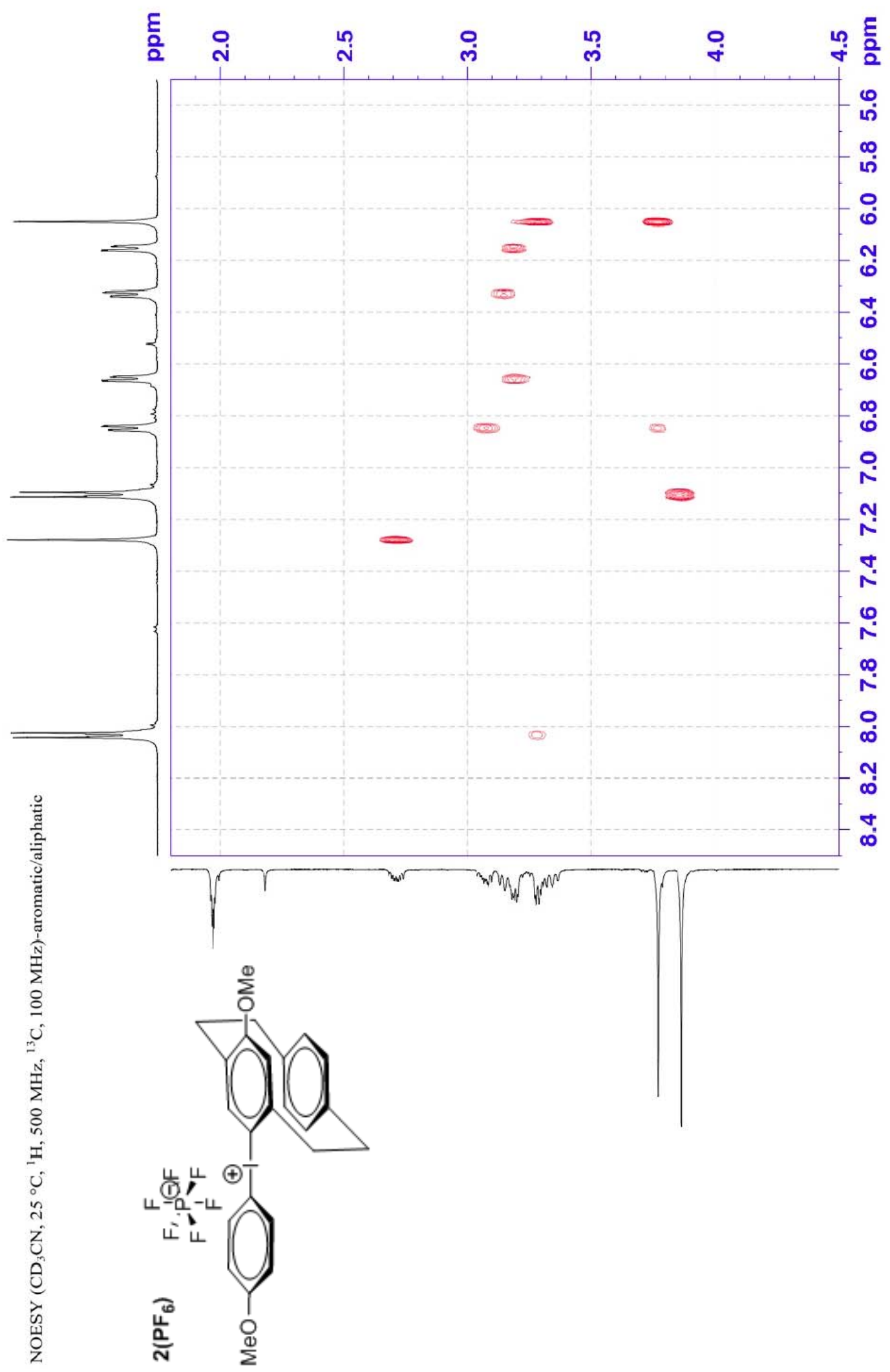

Figure S21. ${ }^{1} \mathrm{H}-{ }^{1} \mathrm{H}$ NOESY NMR spectrum (detail) of $\mathbf{2}\left(\mathbf{P F}_{\mathbf{6}}\right)$ in $\mathrm{CD}_{3} \mathrm{CN}$. 


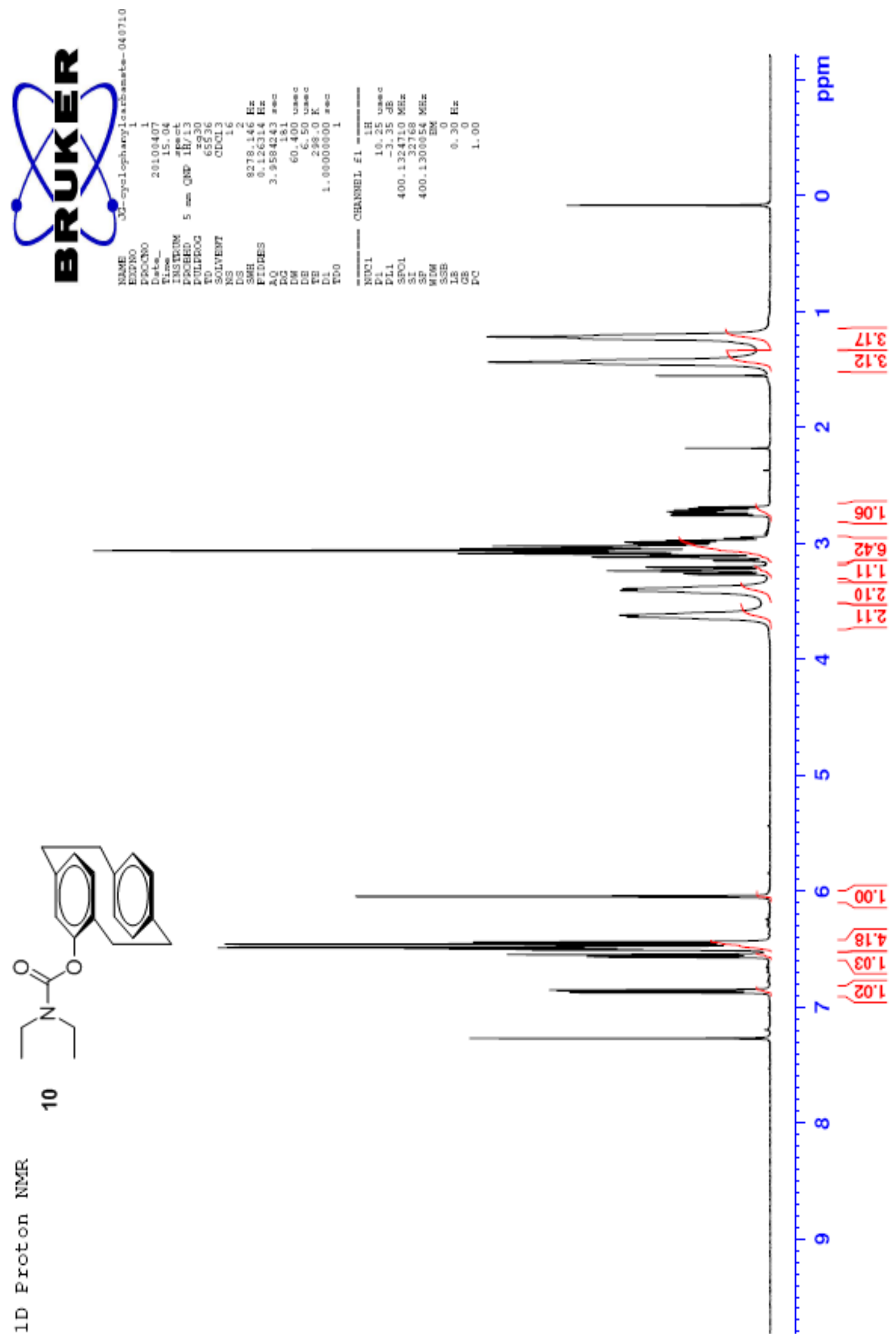

Figure S22. ${ }^{1} \mathrm{H}$ NMR spectrum of 4-diethylcarbamoyl[2.2]paracyclophane in $\mathrm{CDCl}_{3}$. 


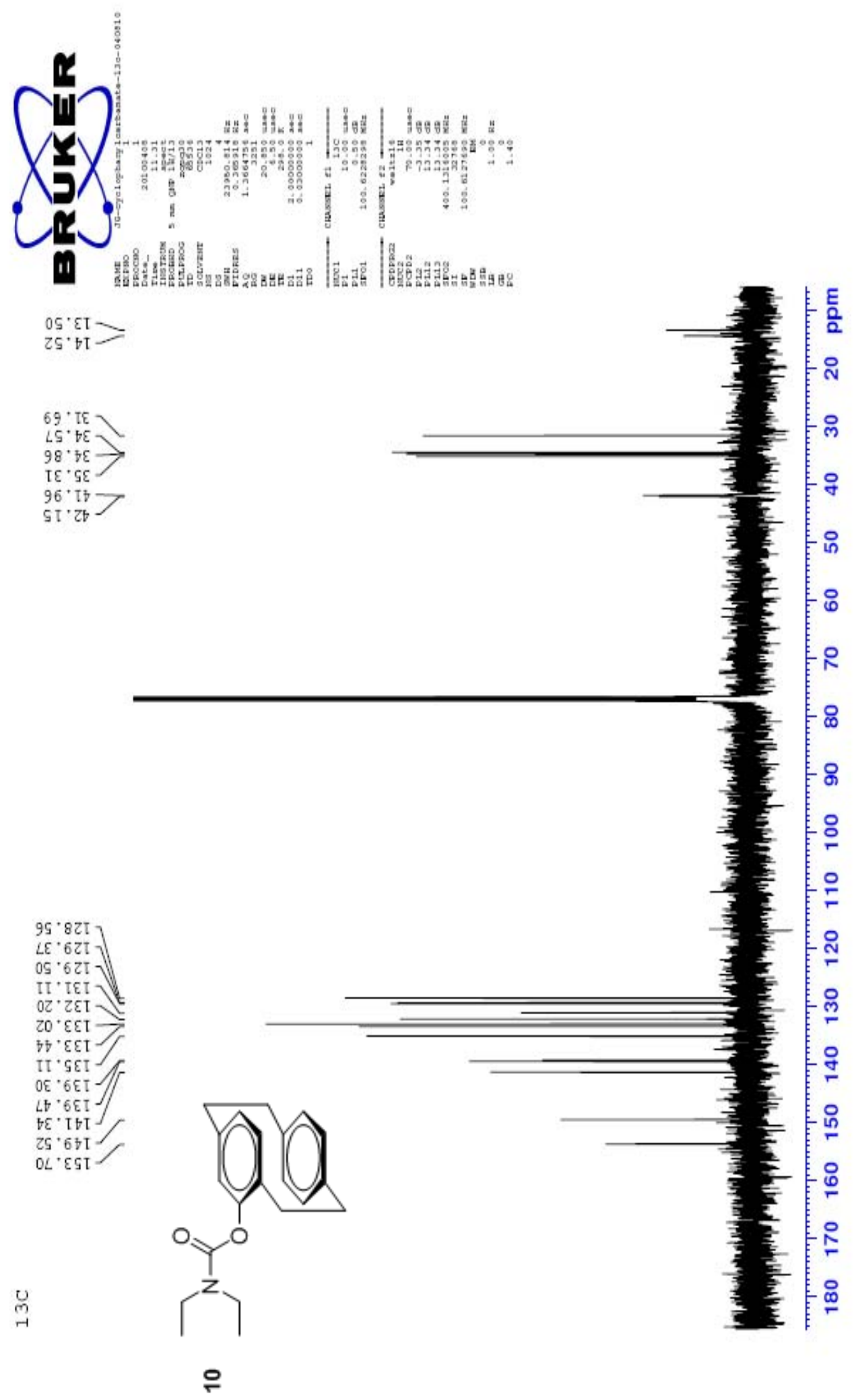

Figure S23. ${ }^{13} \mathrm{C}$ NMR spectrum of 4-diethylcarbamoyl[2.2]paracyclophane in $\mathrm{CDCl}_{3}$. 

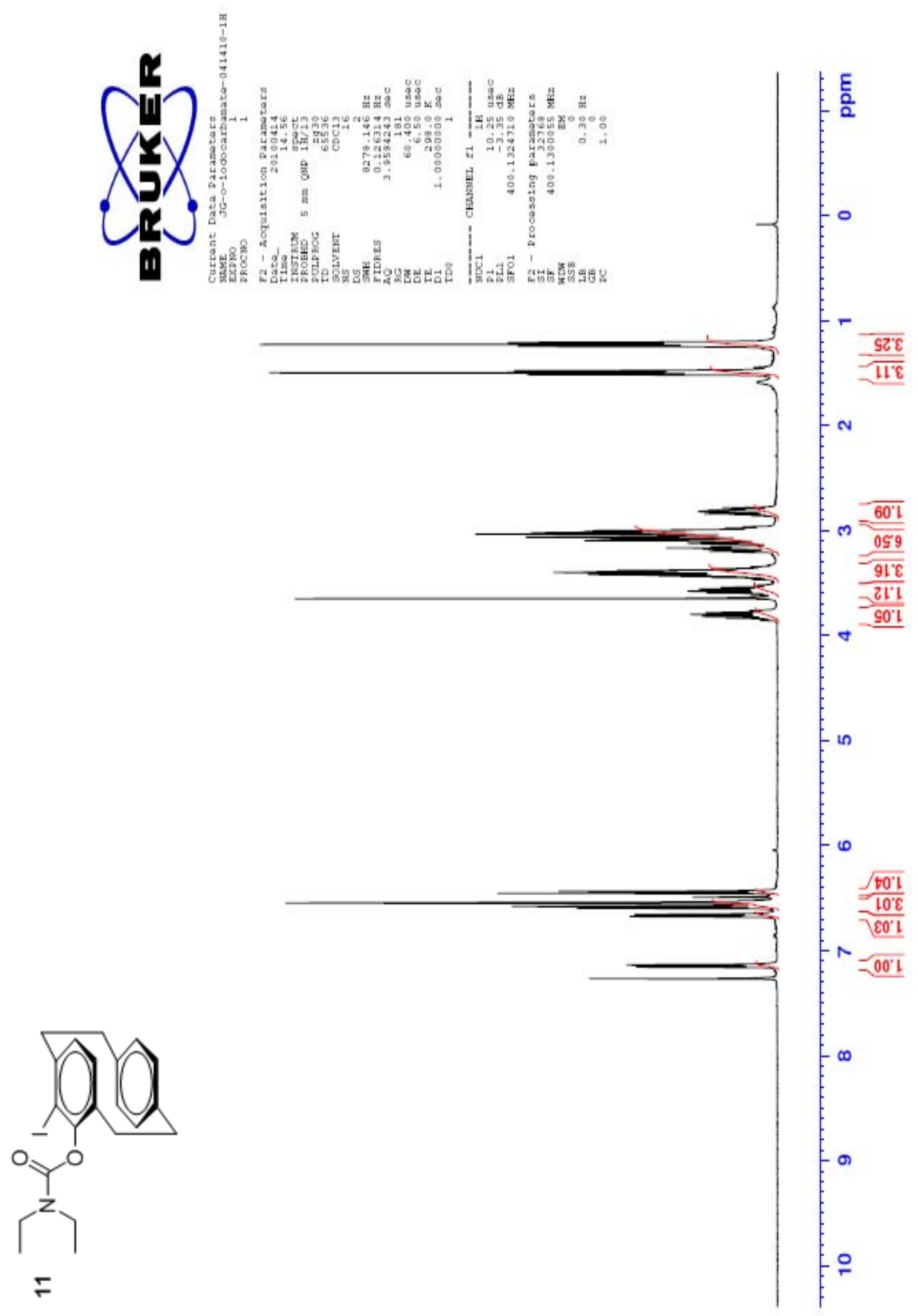

Figure S24. ${ }^{1} \mathrm{H}$ NMR spectrum of 4-diethylcarbamoyl-5-iodo[2.2]paracyclophane in $\mathrm{CDCl}_{3}$. 

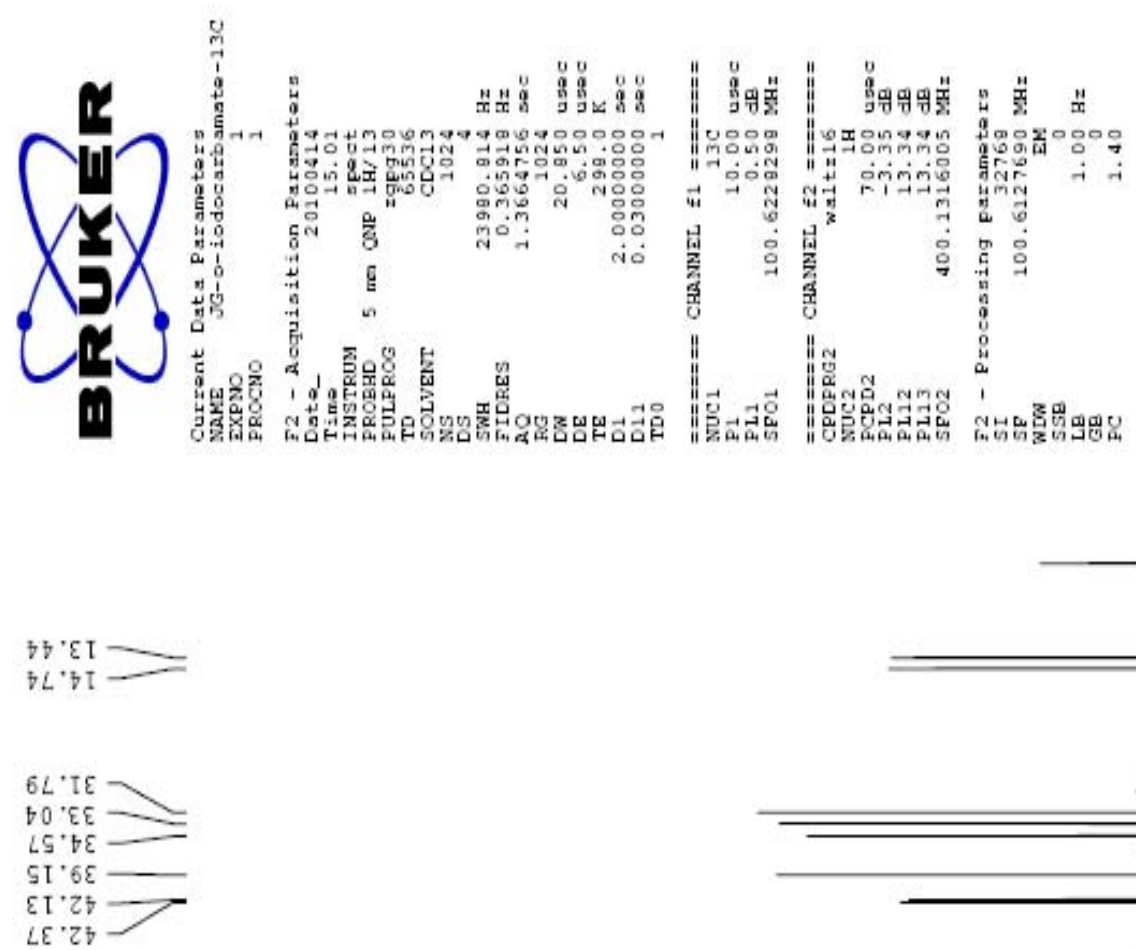

$9 \mathrm{~S}^{\circ} \mathrm{EOT}-$

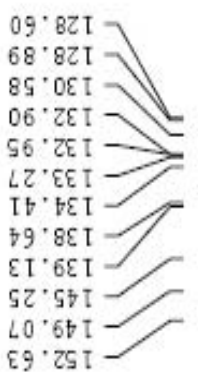

$89.75 T$
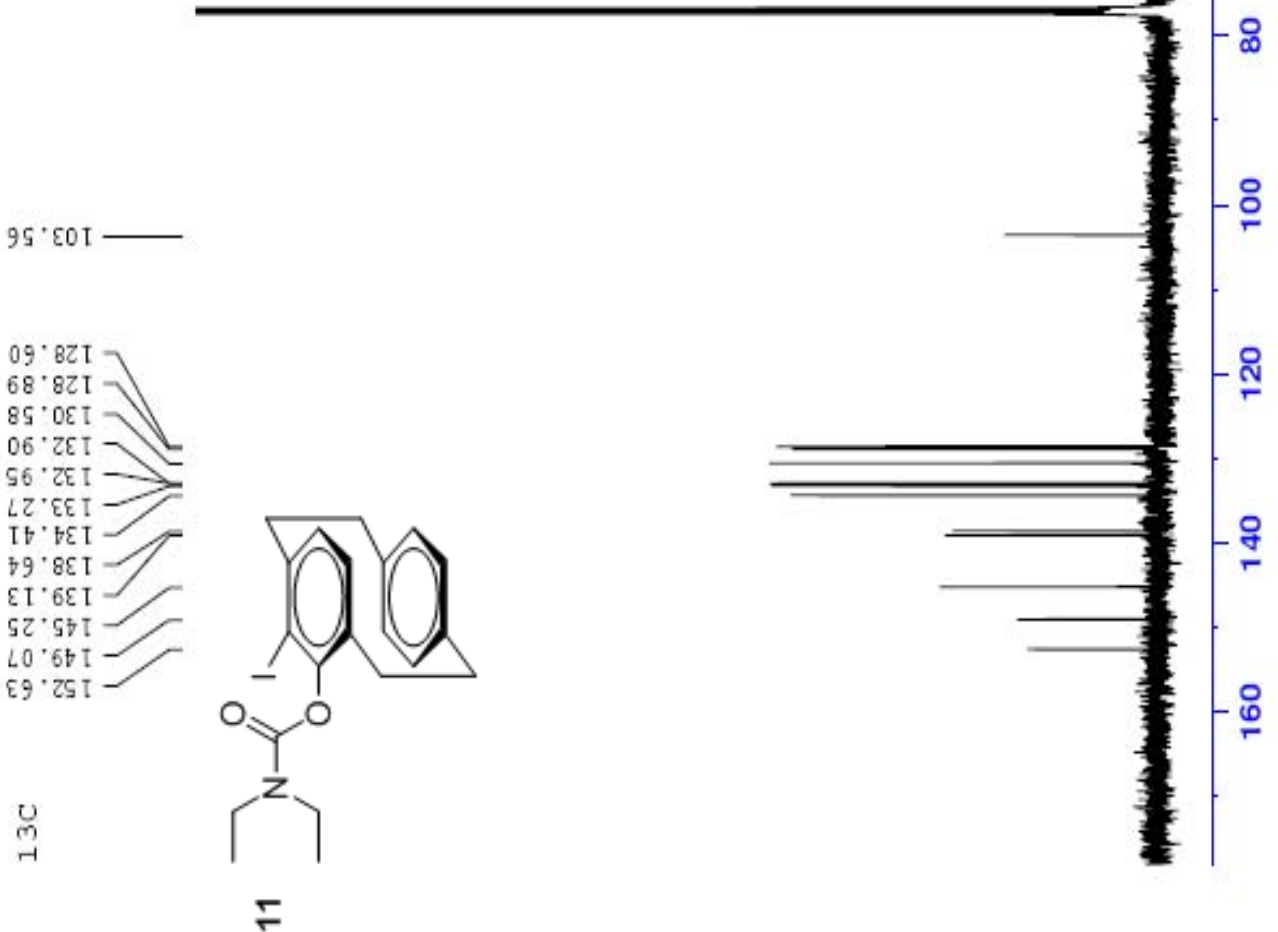

Figure S25. ${ }^{13} \mathrm{C}$ NMR spectrum of 4-diethylcarbamoyl-5-iodo[2.2] paracyclophane in $\mathrm{CDCl}_{3}$. 

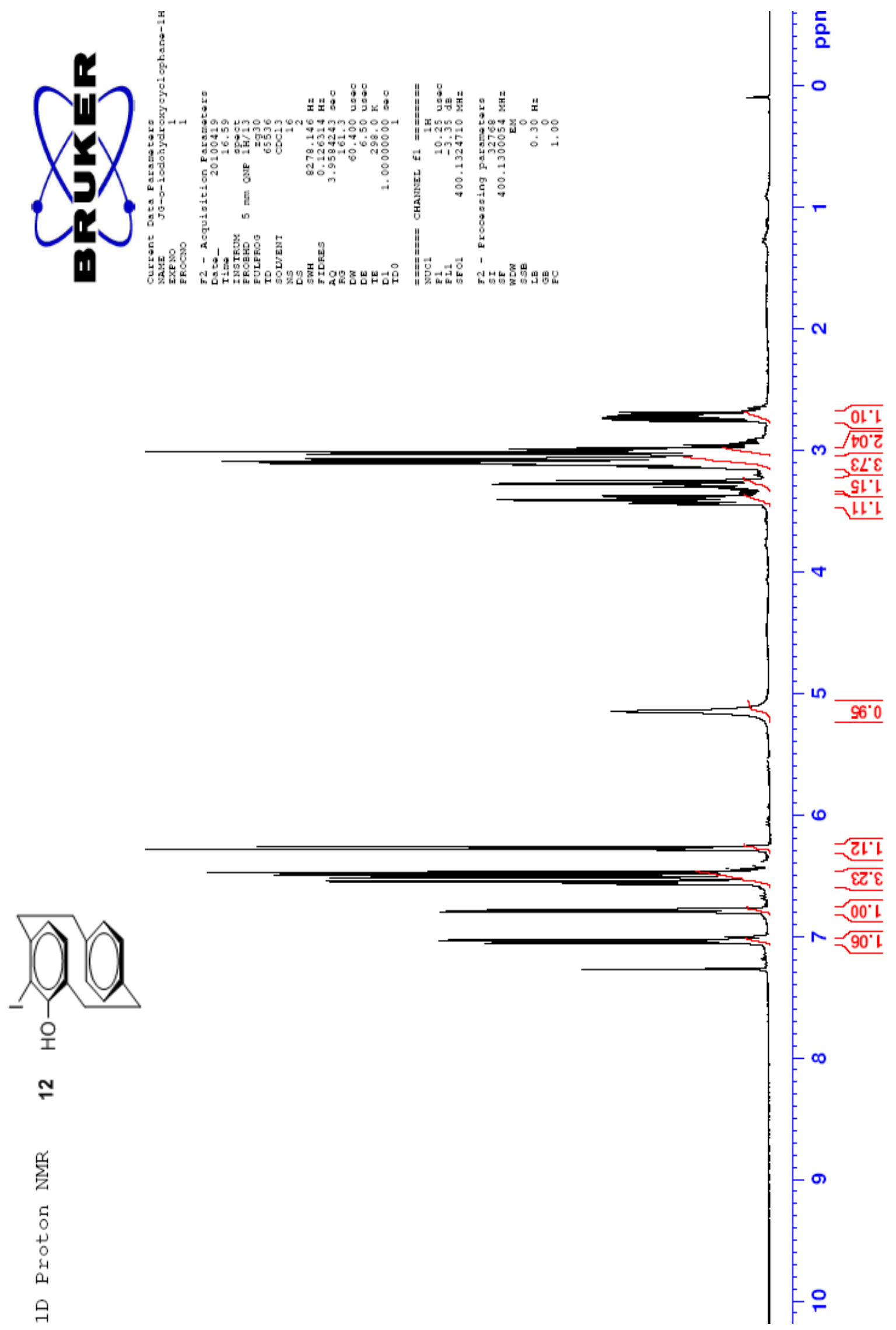

Figure S26. ${ }^{1} \mathrm{H}$ NMR spectrum of 4-hydroxy-5-iodo[2.2]paracyclophane in $\mathrm{CDCl}_{3}$. 


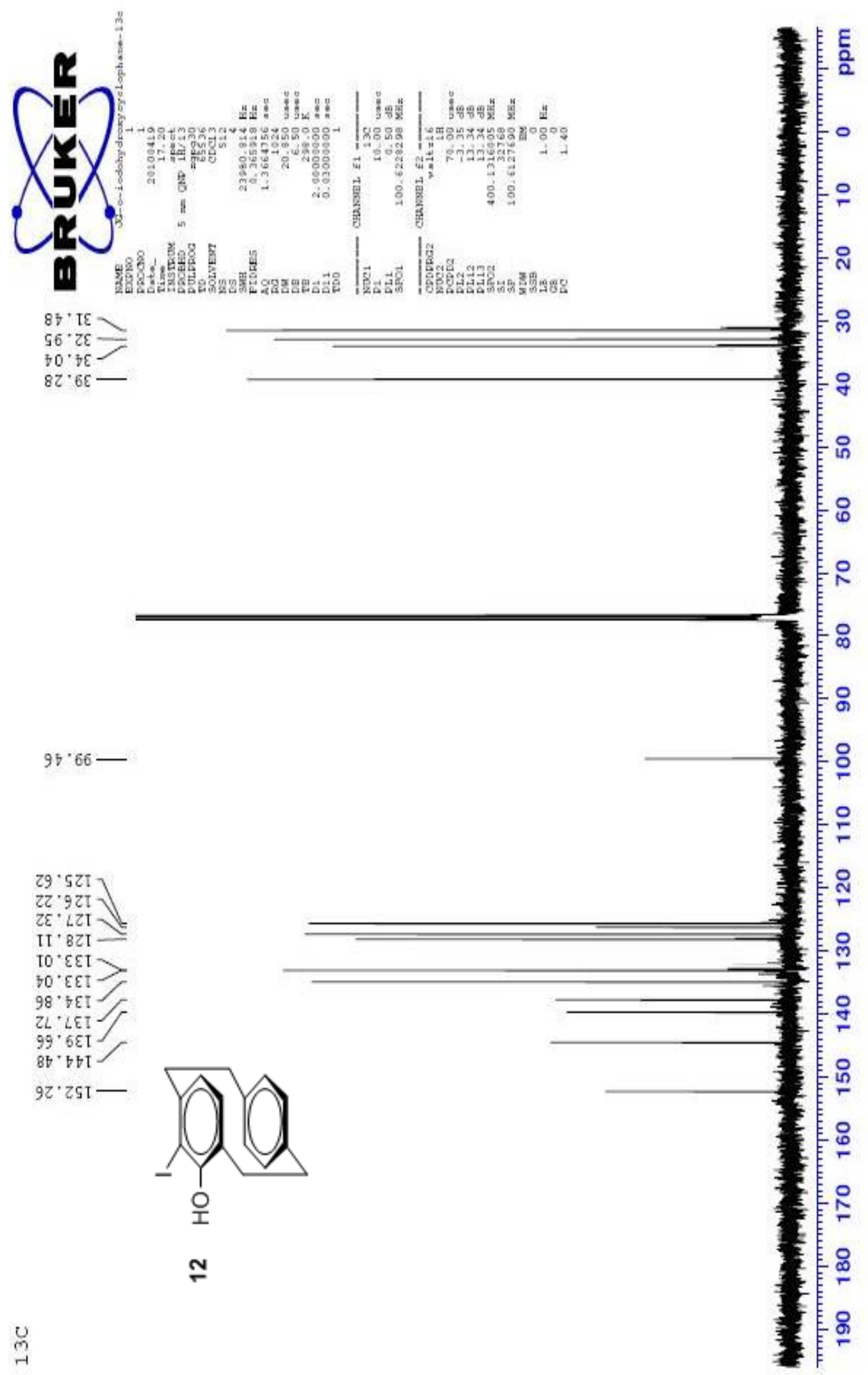

Figure S27. ${ }^{13} \mathrm{C}$ NMR spectrum of 4-hydroxy-5-iodo[2.2]paracyclophane in $\mathrm{CDCl}_{3}$. 

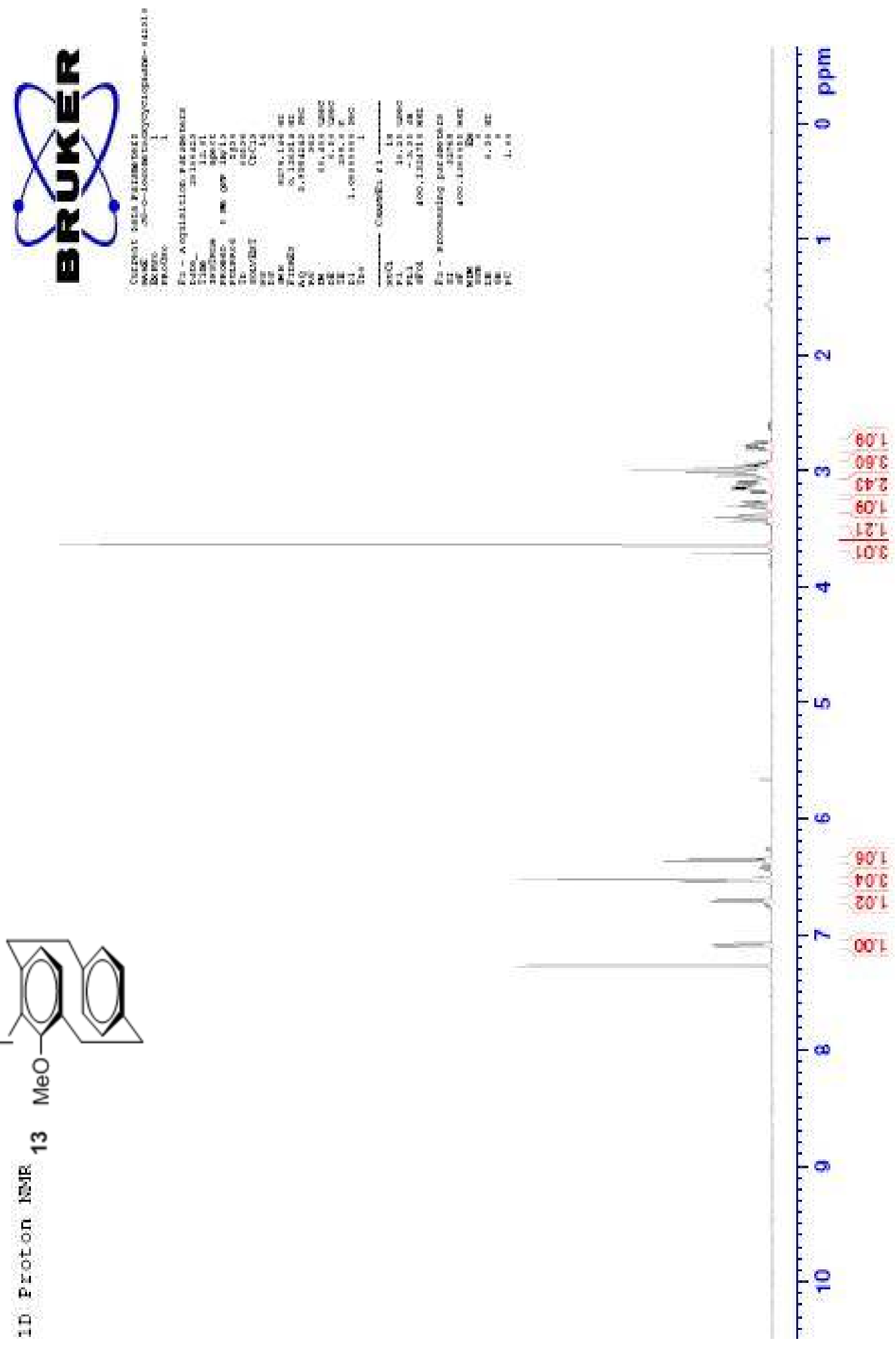

Figure S28. ${ }^{1} \mathrm{H}$ NMR spectrum of 4-methoxy-5-iodo[2.2]paracyclophane in $\mathrm{CDCl}_{3}$. 

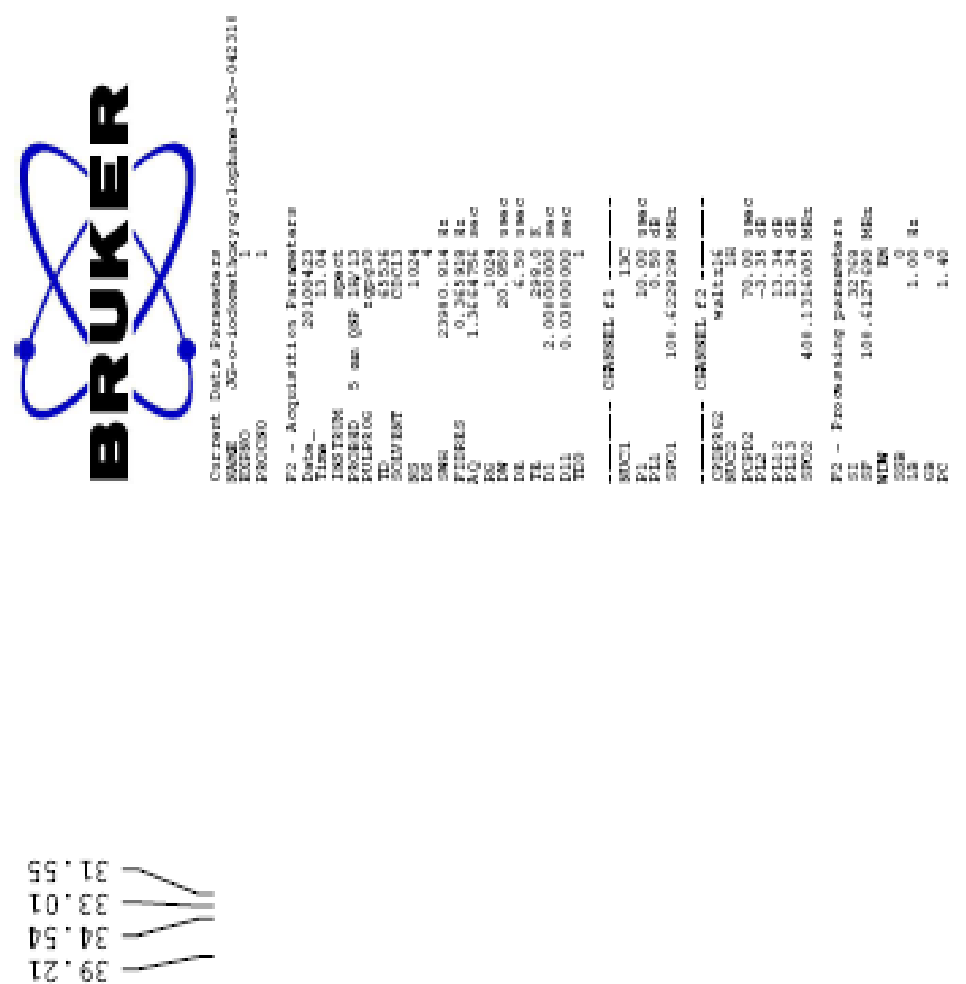

$96.09-$
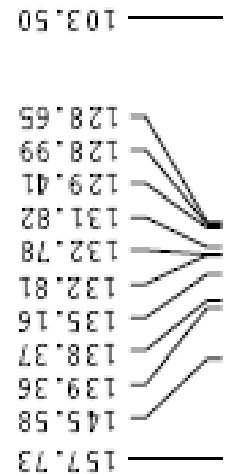

$\varepsilon L . L S T$

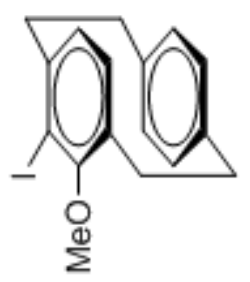

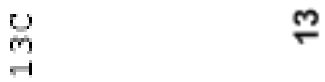

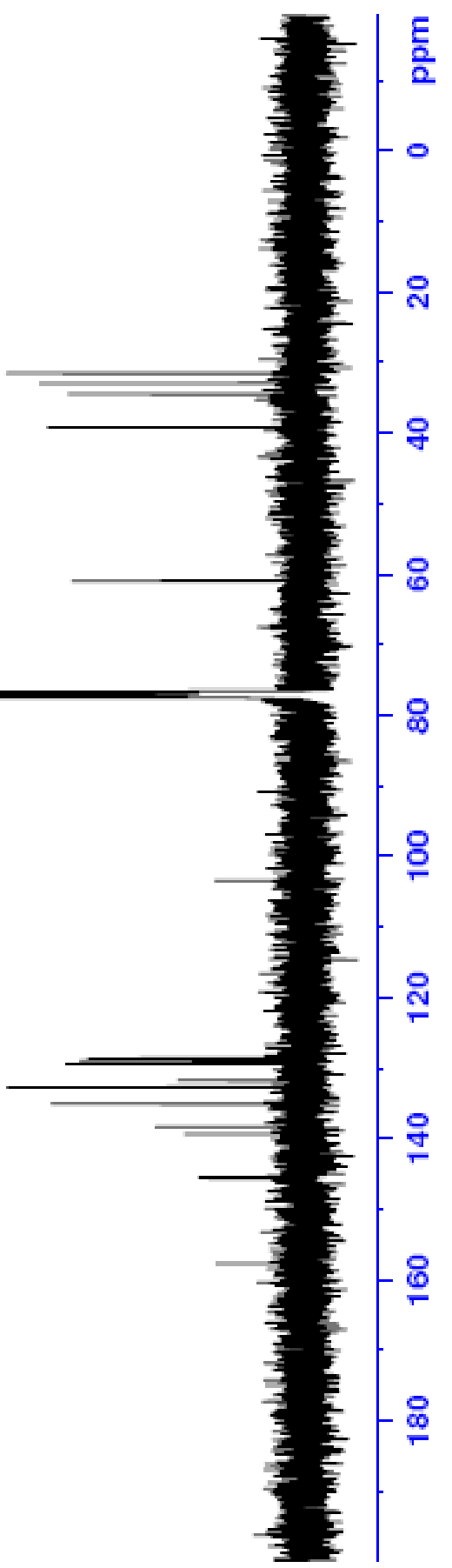

Figure S29. ${ }^{13} \mathrm{C}$ NMR spectrum of 4-methoxy-5-iodo[2.2]paracyclophane in $\mathrm{CDCl}_{3}$ 

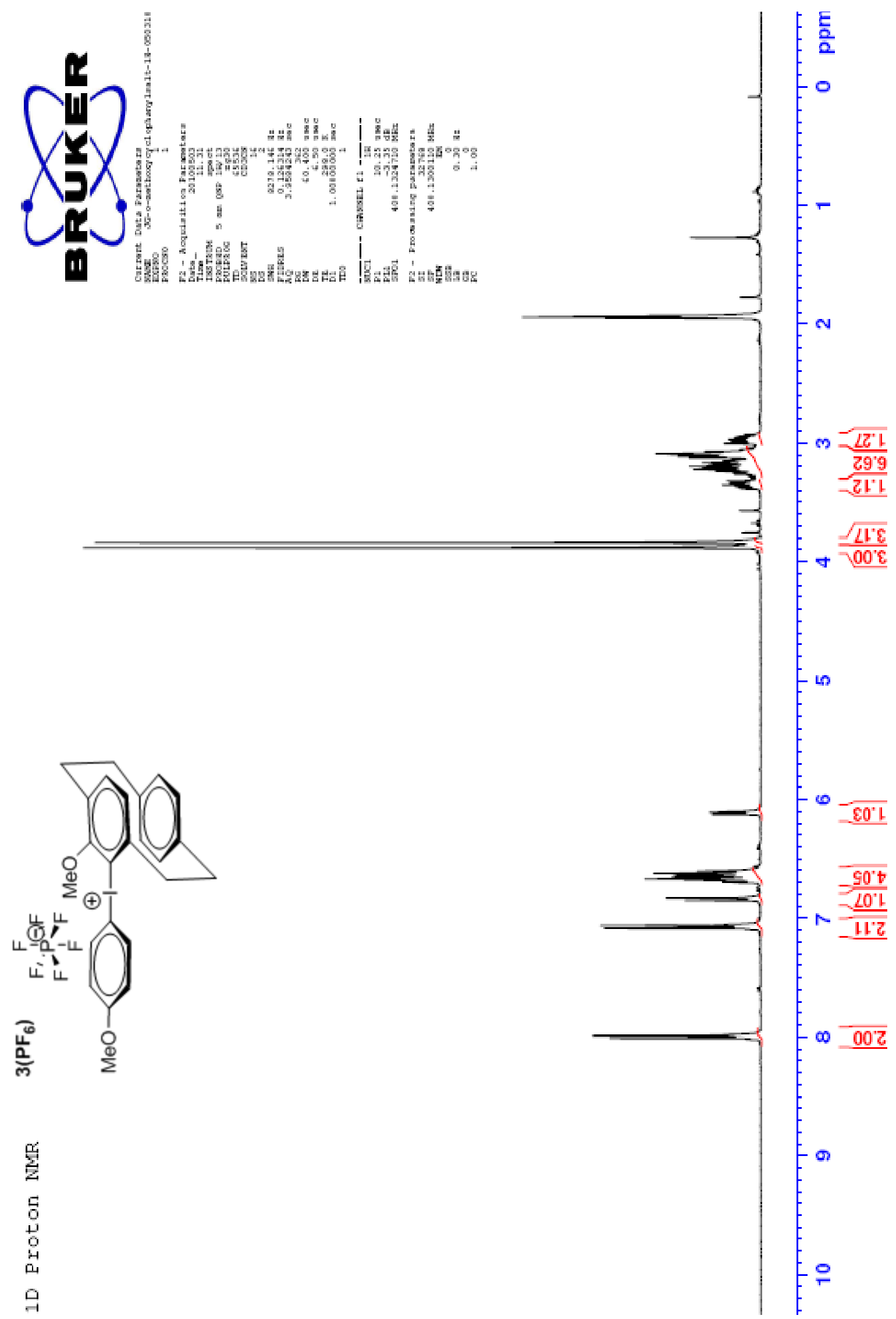

Figure S30. ${ }^{1} \mathrm{H}$ NMR spectrum of $\mathbf{3}\left(\mathbf{P F}_{\mathbf{6}}\right)$ in $\mathrm{CD}_{3} \mathrm{CN}$. 


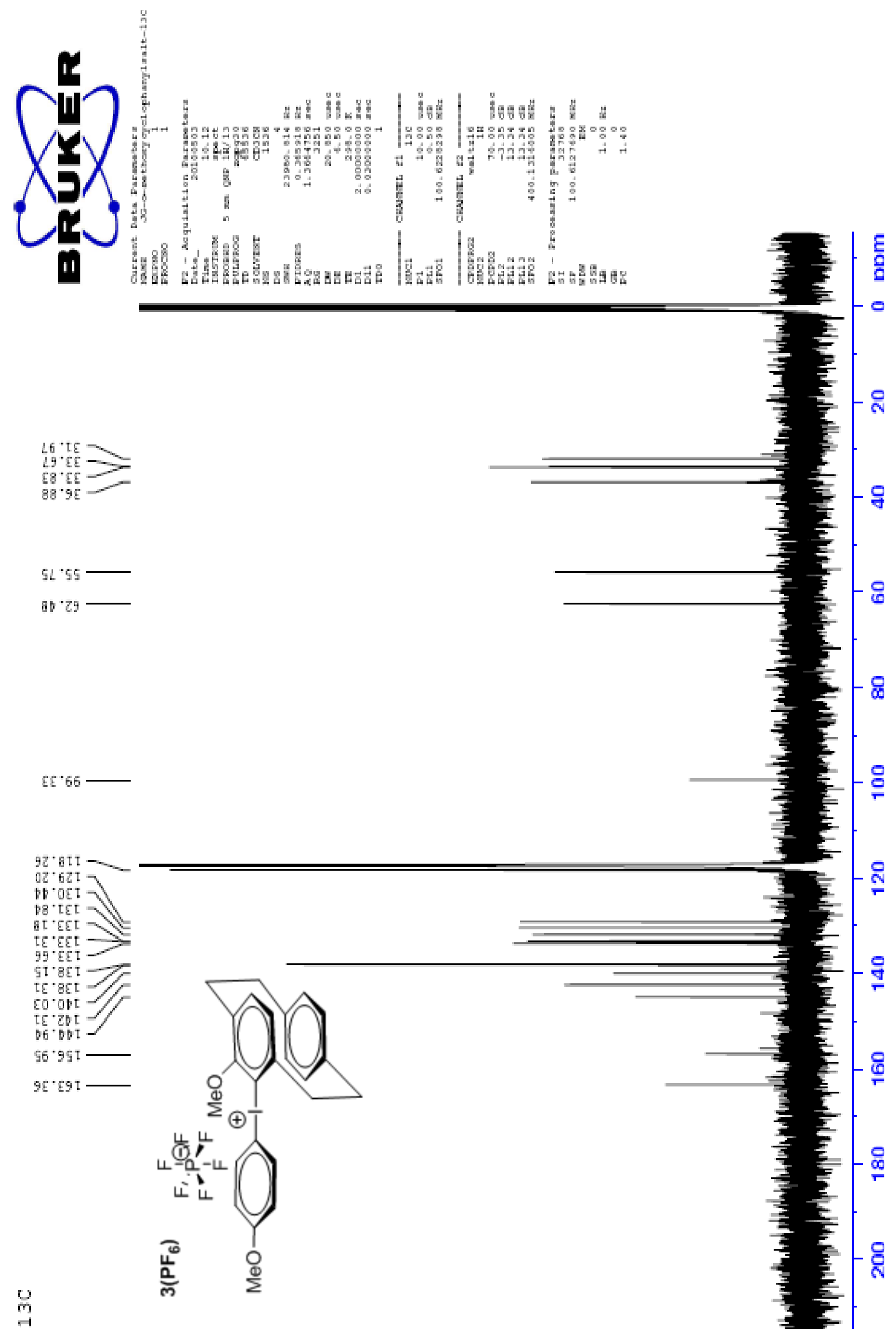

Figure S31. ${ }^{13} \mathrm{C}$ NMR spectrum of $\mathbf{3}\left(\mathbf{P F}_{\mathbf{6}}\right)$ in $\mathrm{CD}_{3} \mathrm{CN}$. 

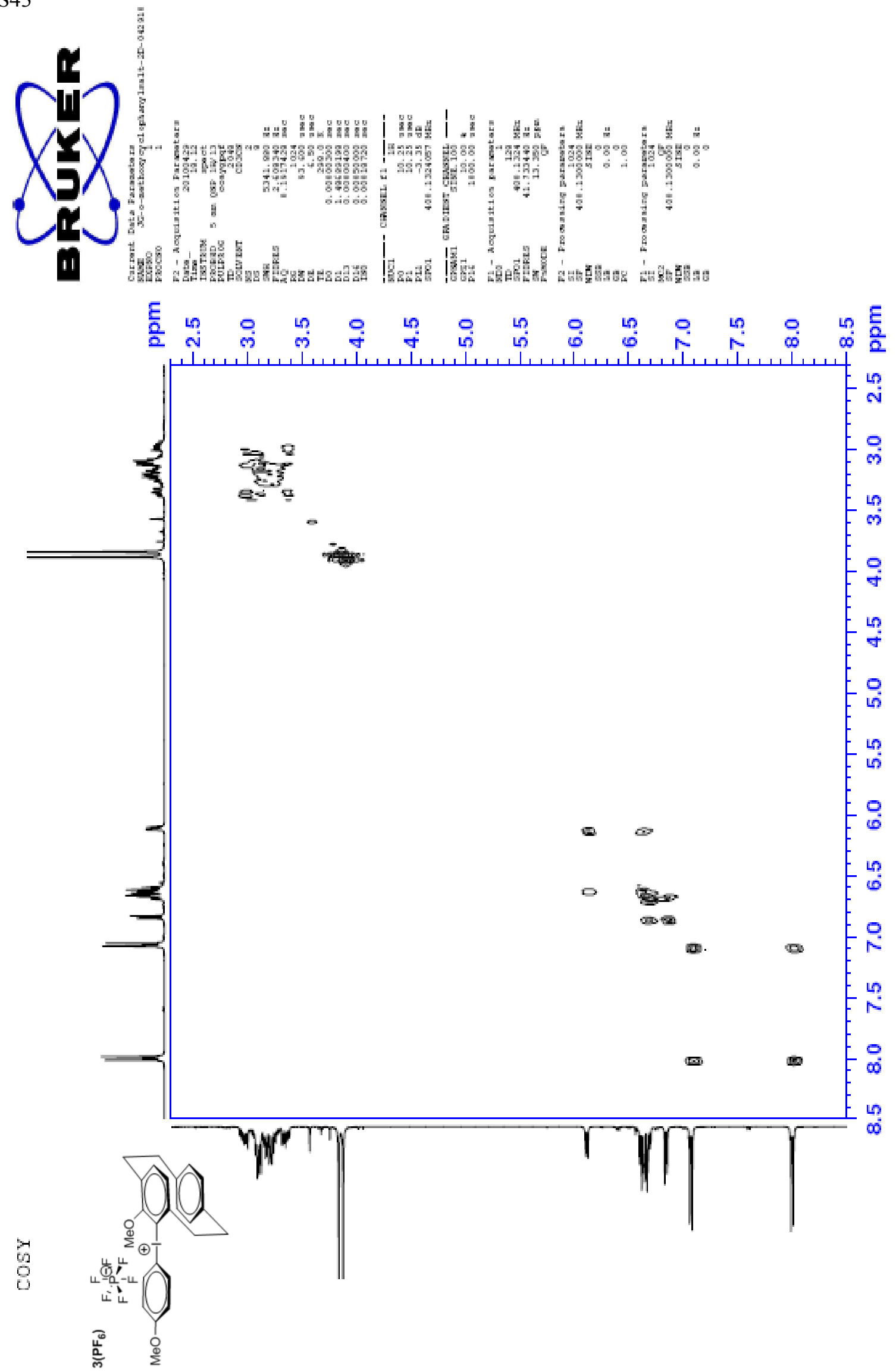

Figure S32. ${ }^{1} \mathrm{H}-{ }^{1} \mathrm{H}$ COSY NMR spectrum of $\mathbf{3}\left(\mathbf{P F}_{\mathbf{6}}\right)$ in $\mathrm{CD}_{3} \mathrm{CN}$. 


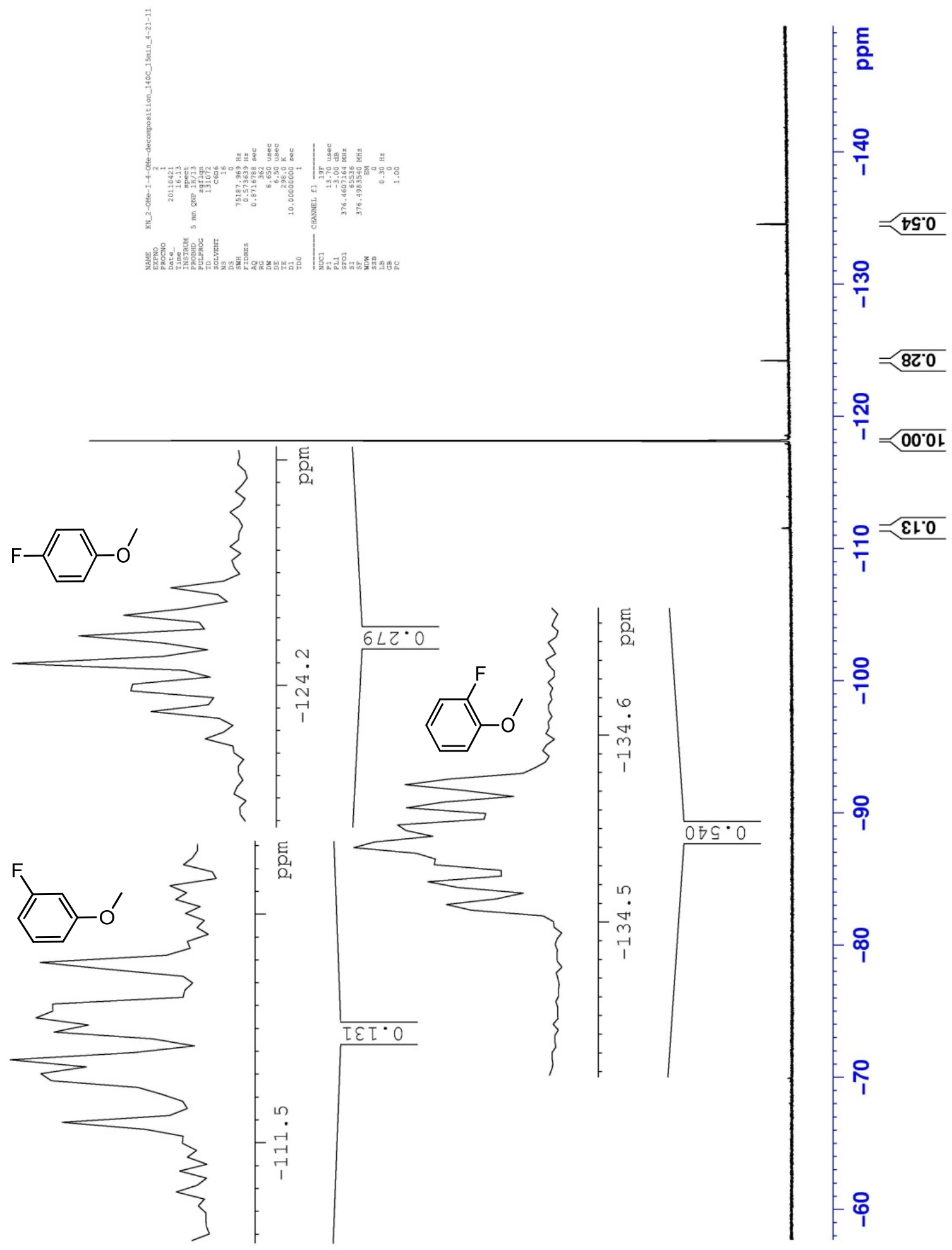

Figure S33. ${ }^{19} \mathrm{~F}$ NMR spectrum (benzene-d $\mathrm{d}_{6}$ ) after thermal decomposition of $\mathbf{5 ( F )}$ at $140{ }^{\circ} \mathrm{C}$. 


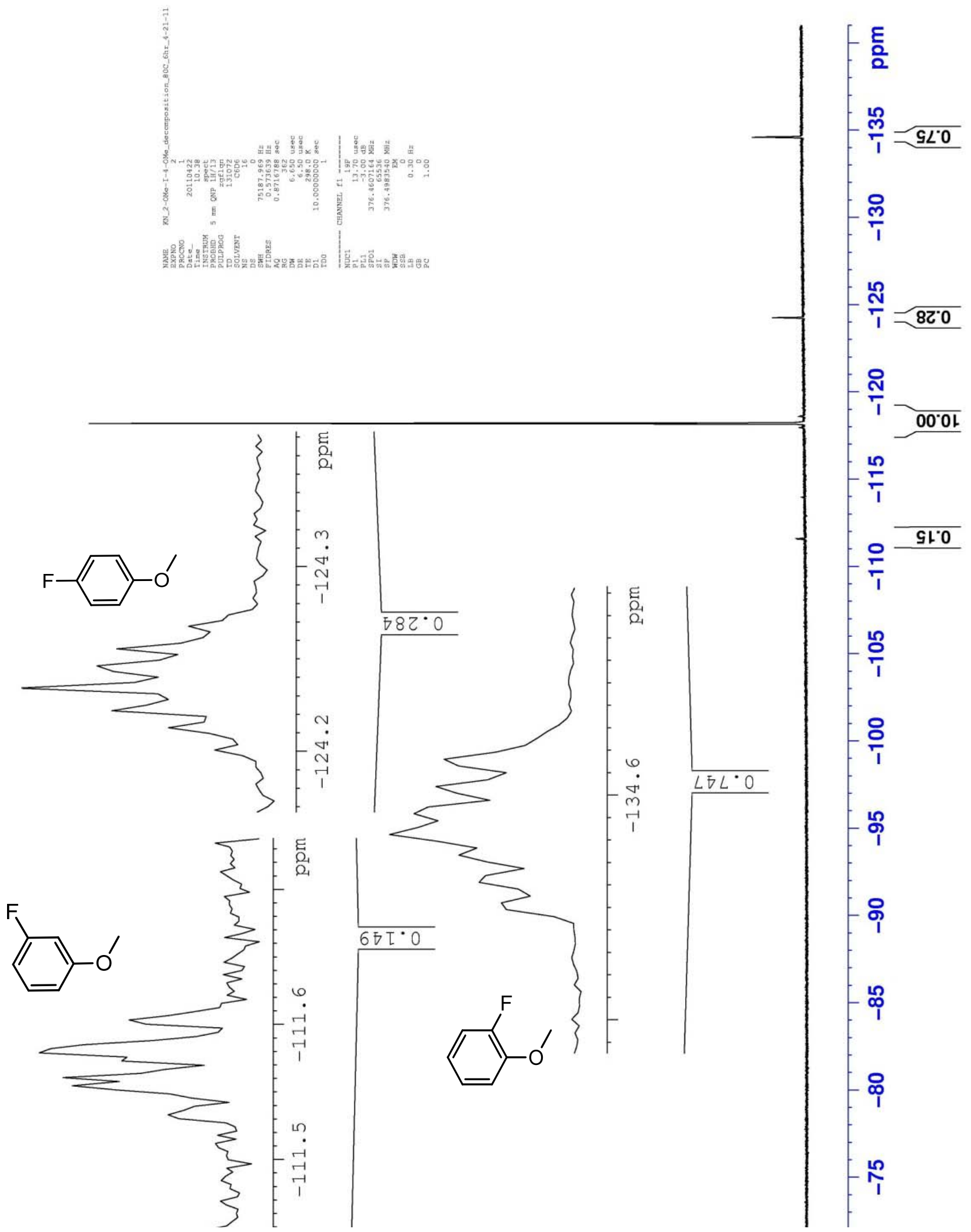

Figure S34. ${ }^{19} \mathrm{~F}$ NMR spectrum (benzene- $\mathrm{d}_{6}$ ) after thermal decomposition of $\mathbf{5 ( F )}$ at $80{ }^{\circ} \mathrm{C}$. 

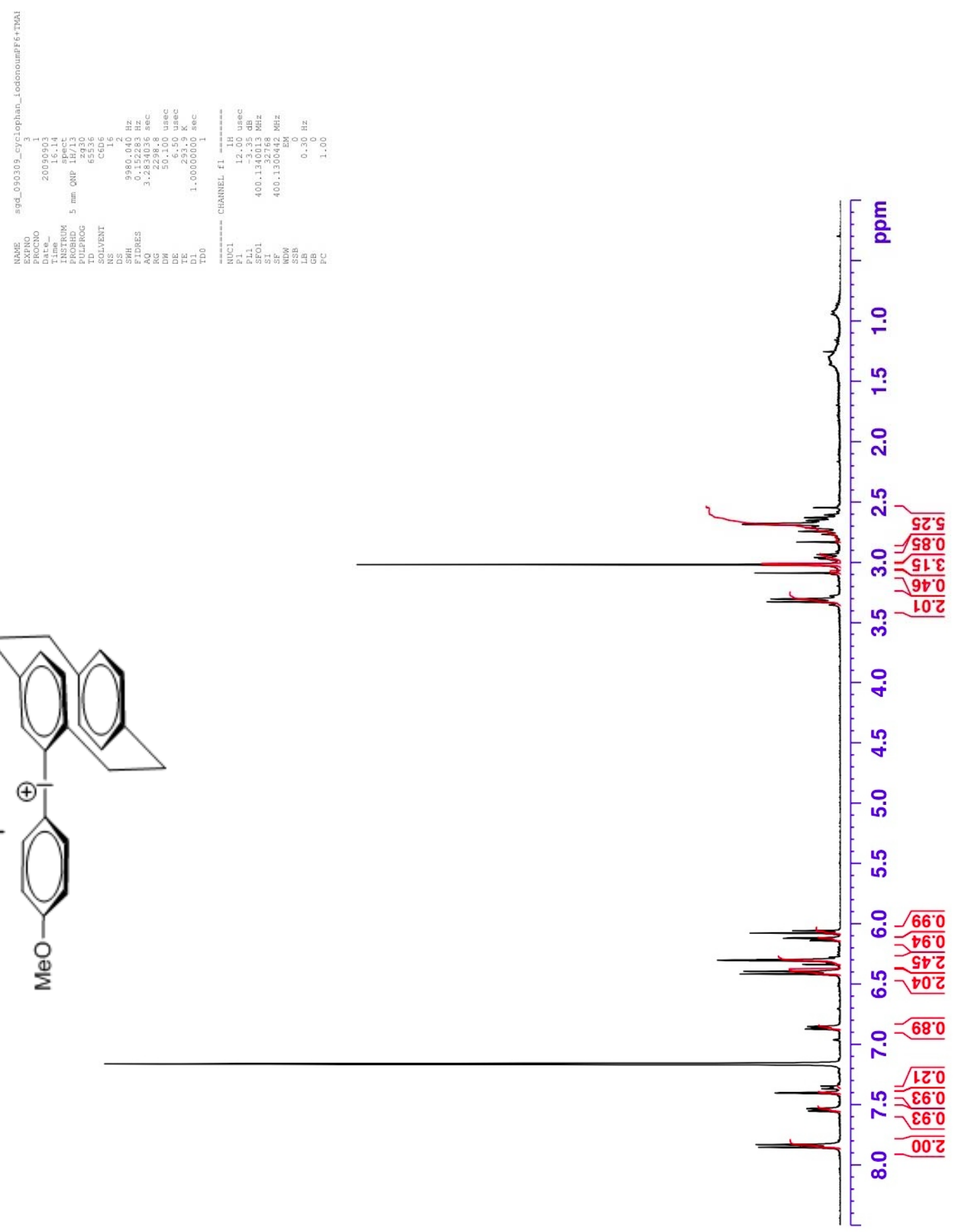

Figure S35. ${ }^{1} \mathrm{H}$ NMR spectrum of $\mathbf{1}(\mathbf{F})$ in $\mathrm{C}_{6} \mathrm{D}_{6}$. 


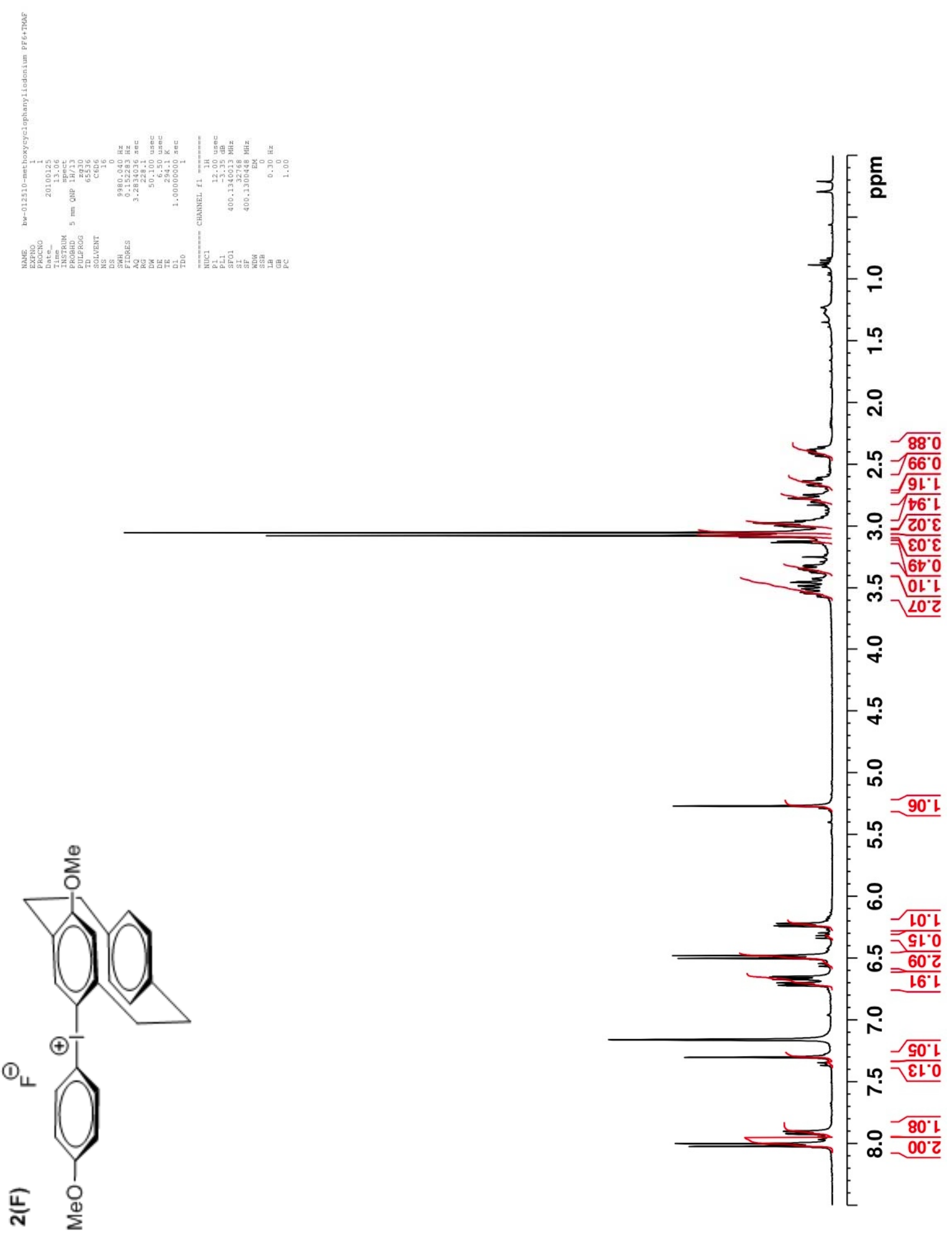

Figure S36. ${ }^{1} \mathrm{H}$ NMR spectrum of $\mathbf{2}(\mathbf{F})$ in $\mathrm{C}_{6} \mathrm{D}_{6}$. 


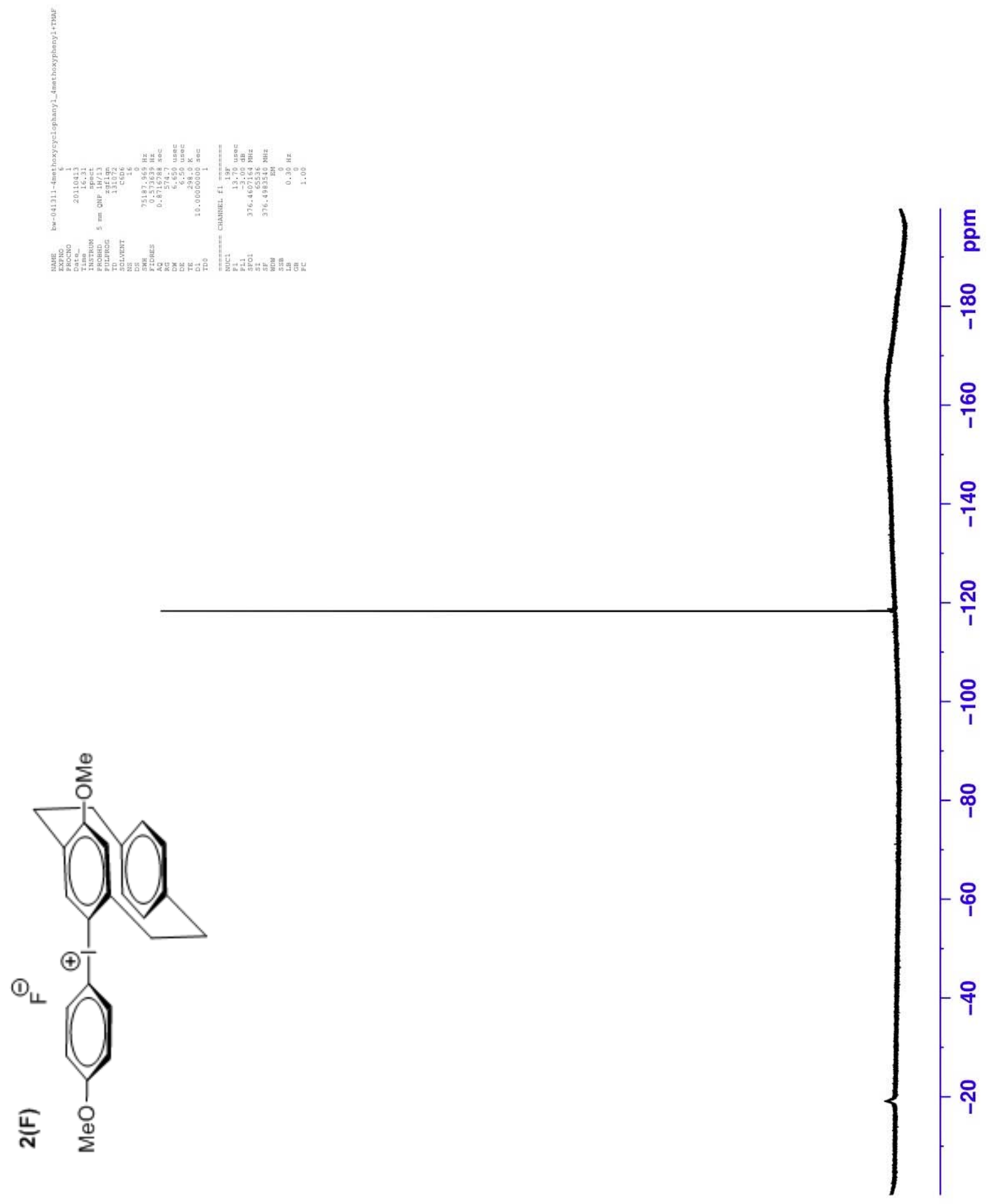

Figure S37. ${ }^{19} \mathrm{~F}$ NMR spectrum of $\mathbf{2 ( F )}$ and 4-fluorotoluene (standard) in $\mathrm{C}_{6} \mathrm{D}_{6}$. 


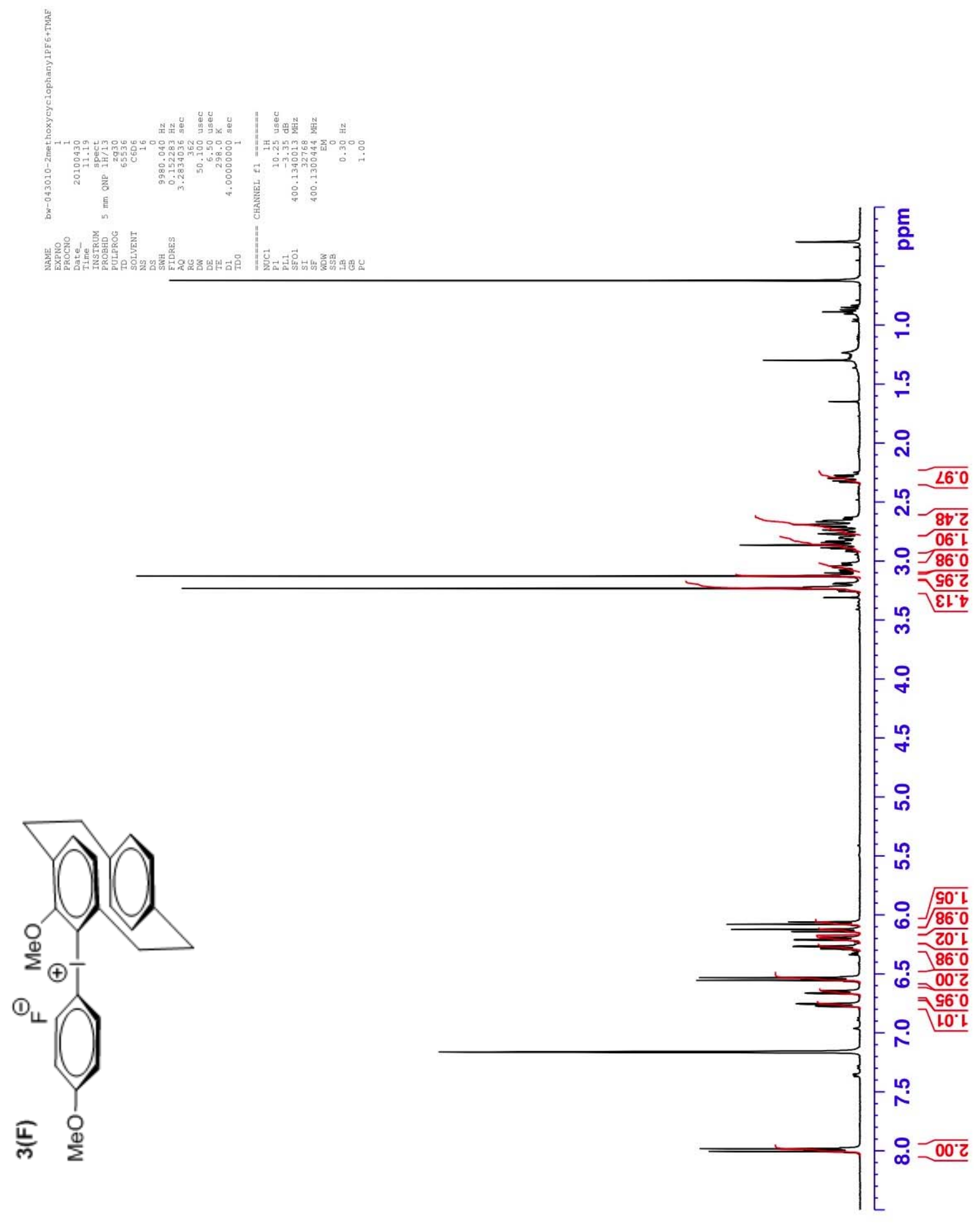

Figure S38. ${ }^{1} \mathrm{H}$ NMR spectrum of $\mathbf{3}(\mathbf{F})$ in $\mathrm{C}_{6} \mathrm{D}_{6}$. 


\section{References cited:}

(1) Wang, B.; Cerny, R. L.; Uppaluri, S.; Kempinger, J. J.; DiMagno, S. G. J. Fluorine Chem. 2010, 131, 1113.

(2) M. J. Frisch, G. W. T., H. B. Schlegel, G. E. Scuseria, M. A. Robb, J. R. Cheeseman, J. A. Montgomery, Jr., T. Vreven, K. N. Kudin, J. C. Burant, J. M. Millam, S. S. Iyengar, J. Tomasi, V. Barone, B. Mennucci, M. Cossi, G. Scalmani, N. Rega, G. A. Petersson, H. Nakatsuji, M. Hada, M. Ehara, K. Toyota, R. Fukuda, J. Hasegawa, M. Ishida, T. Nakajima, Y. Honda, O. Kitao, H. Nakai, M. Klene, X. Li, J. E. Knox, H. P. Hratchian, J. B. Cross, V. Bakken, C. Adamo, J. Jaramillo, R. Gomperts, R. E. Stratmann, O. Yazyev, A. J. Austin, R. Cammi, C. Pomelli, J. W. Ochterski, P. Y. Ayala, K.

Morokuma, G. A. Voth, P. Salvador, J. J. Dannenberg, V. G. Zakrzewski, S. Dapprich, A. D. Daniels, M. C. Strain, O. Farkas, D. K. Malick, A. D. Rabuck, K. Raghavachari, J. B. Foresman, J. V. Ortiz, Q. Cui, A. G. Baboul, S. Clifford, J. Cioslowski, B. B. Stefanov, G. Liu, A. Liashenko, P. Piskorz, I. Komaromi, R. L. Martin, D. J. Fox, T. Keith, M. A. Al-Laham, C. Y. Peng, A. Nanayakkara, M. Challacombe, P. M. W. Gill, B. Johnson, W. Chen, M. W. Wong, C. Gonzalez, and J. A. Pople. Gaussian, Inc., Wallingford CT, 2004.

(3) Katritzky, A. R.; Gallos, J. K.; Durst, H. D. Magn. Reson. Chem. 1989, 27, 815.

(4) Cerioni, G.; Uccheddu, G. Tetrahedron Lett. 2004, 45, 505.

(5) Carroll, M. A.; Nairne, J.; Smith, G.; Widdowson, D. A. J. Fluorine Chem. 2007, 128,

127.

(6) Cram, D. J.; Day, A. C. J. Org. Chem. 1966, 31, 1227.

(7) Krohn, K.; Rieger, H.; Hopf, H.; Barrett, D.; Jones, P. G.; Doering, D. Chem. Ber. 1990, $123,1729$.

(8) Rozenberg, V.; Zhuravsky, R.; Sergeeva, E. Chirality 2006, 18, 95.

(9) Hopf, H.; Barrett, D. G. Liebigs Ann. 1995, 449.

(10) Wack, H.; France, S.; Hafez, A. M.; Drury, W. J., III; Weatherwax, A.; Lectka, T. J. Org. Chem. 2004, 69, 4531. 